\title{
WDRKING
}

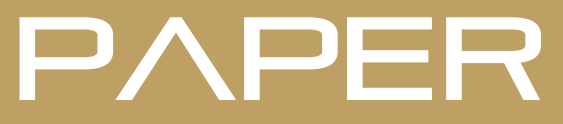

New organizational models in European Local Public Transport:

from Myth to Reality

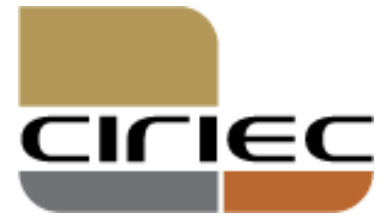

Andrea ZATTI

CIRIEC N ${ }^{\circ}$ 2011/06 
CIRIEC activities, publications and researches are realised with the support of the Belgian Federal Government - Scientific Policy and with the support of the Belgian French Speaking Community - Scientific Research.

Les activités, publications et recherches du CIRIEC sont réalisées avec le soutien du Gouvernement fédéral belge - Politique scientifique et avec celui de la Communauté française de Belgique - Recherche scientifique.

\section{ISSN 2070-8289}

\section{(c) CIRIEC}

No part of this publication may be reproduced.

Toute reproduction même partielle de cette publication est strictement interdite. 
Local public services: Facts, experiences and prospects

\title{
New organizational models in European Local Public Transport: from Myth to Reality" \\ Synthesis Report
}

\author{
Andrea ZATTI ${ }^{* *}$
}

CIRIEC International Scientific Commission on «Public Services / Public Enterprises »

\section{Working paper CIRIEC $N^{\circ}$ 2011/06}

\footnotetext{
* Research carried out with the contribution of the Italian Ministry of Education, University and Research (MIUR) - PRIN 2008.

** University of Pavia and CIRIEC-Italia.
} 


\section{Foreword}

While during the second post-war period public services ${ }^{1}$ were almost everywhere in Europe directly provided by the State or by local governments, it is commonly assumed (Sumet Ongkittikul, 2007; Bognetti, Oberman, 2008; Shulten et al., 2008; Flecker et al., 2009) that a clear move towards liberalization and privatization took place in more recent decades, bringing about a profound alteration of organizational models and market structures. The underlying hypothesis $^{2}$ is that new guidelines and rules adopted by the European Commission and by the EU Court, deeply influenced by the evolution of the theoretical background, must have created pressure for Member States to progressively converge towards a common model of governing services, characterized, among others, by the separation of roles, contracting out, market contestability, attraction of private investors, performance measurement, etc.

The main aim of this paper is to investigate if and to what extent this new dominant policy paradigm (Doronzo, Florio, 2007) actually emerges in the case of European Local Public Transport (LPT), or if and to what extent more fragmented and heterogeneous outcomes prevail. With our analysis, we do not want to draw conclusions on the adequacy of the single organizational form, but mainly to present differences and similarities in order to facilitate mutual understanding and learning.

The empirical insight is based on 9+1 country studies - Austria, Belgium, France, Germany, Great Britain, Italy, Poland, Spain, Sweden, - where GB, due to the very different organizational models adopted, is split between London and outside London. Selected countries guarantee a wide degree of representativeness, both from an historical point of view - 4 EU founding members (Belgium, France, Germany, Italy) + at least one member from each of the following enlargements (GB, Spain, Austria-Sweden, Poland); and from a geographical one, since all more significant and alternative macro-areas are included (continental Europe, Benelux, British Isles, Scandinavian countries, Mediterranean countries, Eastern Europe).

\footnotetext{
${ }^{1}$ In this paper, albeit aware of the recent attempt carried on by the European institutions to avoid the use of the term "public services" and to create a new common nomenclature based on the term "service of general interest", we opt for using "public services" and "services of general interest-SGIs" as equivalent terms.

${ }^{2}$ For example in Flecker et al. (2009, p. 37): "The promotion of liberalisation (and more recently also privatisation) of public services have been one of the core political projects of the European Union since the 1990s. ... Since 2000, the advanced liberalisation policy of growing parts of public services has also become a core element of the Lisbon strategy" or Sumet Ongkittikul (2007, p. 10): "the privatization and deregulation of the bus industry, which brought about competition, induced the establishment of private operators whose purpose is to generate profits as commercial organizations".
} 
Data and information sources are mixed: ad hoc CIRIEC reports by national experts ${ }^{3}$ have been integrated and complemented by the results of the most recent EU driven studies and projects and by selected papers and web factsheets.

\section{Principles and Concepts}

Local public transport services can be identified as those passengers services provided to the public on a non-discriminatory and continuous basis, according to pre-established tariffs, routes and timetables, and designed to meet users' mobility requirements on a small (urban) or medium (inter-urban) territorial scale. This definition, although flexible and characterized by possible differences from country to country, essentially excludes long-distance national services - nearly all coach networks, inter-city rail and aviation, - as well as unscheduled public transport (taxis and other demand-responsive modes) and services not available to the general public (most health and social services transport, some education transport). That leaves buses, trains, and modes that are important in specific locations, such as tram, metro, and ferry, when providing services in a systematic manner, to a geographically restricted territory and with conventional frequencies and stops.

\subsection{General interest in LPT}

Even if the clear identification of the category of Services of General Interest (SGIs) is not immediate, the mainstream economic theorizing of the provision of SGIs is tied to the concept of market failure ${ }^{4}$. Public interest emerges when market is thought to fail to provide an adequate - both quantitatively and qualitatively - level of services and when more commonly considered causes of market failures (monopolistic power, externalities and public goods, asymmetric information, merit goods and cream skimming) are likely to occur. This idea is clearly included even in the European Commission's approach, as "Services of general economic interest are different from ordinary services in that public authorities consider that they need to be provided even where the market may not have sufficient incentives to do so" or "the public authorities consider that

\footnotetext{
${ }^{3}$ Available on the website http://www.ciriec.ulg.ac.be/en/pages/6_2working_papers.htm.

4 "There is a SGI when it is decided or recognised by a public authority or case law that certain activities are not subject to the common law of competition or market rules, but also to particular rules and norms, to purposes and objectives ensuring access to every resident, the establishment of relations of solidarity, of economic, social and territorial cohesion, and/or the creation of remedies to market failures (in the economic, environmental, territorial sphere, or taking into account the long term)" (Bauby, Similie, 2010, p. 35-36).
} 
certain services are in the general interest and market forces may not result in a satisfactory provision". 5

In this perspective, it is commonly recognized that important general or public interests can be related to the provision of Local public transport (LPT) services, above all in urban areas, and therefore justify the introduction of public service obligations $^{6}$ by Member States and, above all, by local authorities ${ }^{7}$.

In short, market failures can be related to:

- indivisibilities and decreasing average costs: many collective transport services have characteristics of natural monopoly, with relevant essential facilities and sunk costs (rail networks, rolling stock, depots, shelters) that can create barriers to the development of competition in the market;

- network and density economies: the existence of strong interdependences throughout the whole transport chain (parking facilities, single lanes, rail and bus services, different type of tickets, timetables, information) can make the presence of one only operator, or, at least, the strict integration of different actors, more efficient;

- social cohesion: collective services ensure accessibility to a basic right transportation - above all for some categories (the so called transport disadvantaged) who cannot fully afford or take advantage of private cars: those too young or too old to drive, low income earners, disabled, ill people, large families, migrants and visitors;

- territorial cohesion: collective services reduce spatial imbalance and disparities. Even if local transport is less important than other services in obtaining spatial cohesion on a wide scale, for example at the European or national level, it is vital to ensure accessibility to specific zones (outskirts, peripheral and rural areas) and avoid discontinuities between the city centre and outer areas;

\footnotetext{
${ }^{5}$ Communication from the Commission: "Services of General Interest in Europe" (2001/C 17/04), p. 7. And, more recently: "the terms (SGEI) refers in general to services of an economic nature that the public authorities in the Member States at national, regional or local level, depending on the allocation of powers between them under the national law, subject to specific public service obligations through an act of entrustment on the basis of a general-interest criterion and in order to ensure that the services are provided under conditions which are not necessarily the same as prevailing market conditions" (European Commission, 2010 p. 15-16).

${ }^{6}$ Public service obligations become the regulatory tool through which competent authorities can correct market failures originating from a purely decentralized approach, in order to meet more general interests: "public service obligation means a requirement defined or determined by a competent authority in order to ensure public transport services in the general interest that an operator, if it were considering its only own commercial interests, would not assume or would not assume to the same extent or under the same conditions without rewards", Regulation (EC) N. 1379/2007 of the European Parliament and of the Council of 23 October 2007 on public passenger transport services by rail and by road (art 2(e)).

${ }^{7}$ As explicitly provided by Article 93 of the consolidated version of the Treaty on the functioning of the European Union.
} 
- sustainable development: they can create conditions - at the local level - for a sustainable development of economic, environmental and social activities. This dimension has progressively become more and more relevant, since the major role played by private cars, constantly associated to economic growth in last decades, created a dynamic trend not sustainable in the long run. If, on the one hand, income growth allowed a partial (of course, far from being complete) reduction of restrictions considered in the previous two points, thanks to the flexibility - both spatial and temporal - offered by private cars, it also contributed to generate important (above all urban) problems: traffic congestion, air pollution, noise pollution, visual intrusion ${ }^{8}$. The outcome can seriously affect the competitiveness and efficient management of local areas and give a new and probably increasing "collective role" to LPT.

The general interest in LPT services has therefore to do with economic efficiency, as well as equity and solidarity, both interpersonal and territorial, in a context where public authorities keep the opportunity/responsibility to decide if and how to get involved, in accordance with their objective function and to the priority given to different issues (environmental, social, public finances, etc). To this end, at least three general aspects should be carefully taken into consideration.

Firstly, the concept of public service is clearly a dynamic concept: areas so treated change over time and space, along with economic development and technological and political change. Technological progress and innovation, for example, can play a role in reducing the importance of the natural monopoly characteristic of certain assets and infrastructures. At the same time, what is considered a general interest highly depends on the "solidarity perimeters" which characterize a given society in a given period (Thiry B., Monnier L., 1997). It follows that the "general interest" is not (or at least not only) one characteristic of an activity as such, but emerges as the result of a political choice and a decision process, which can progressively evolve and transform (Obermann, 2007) ${ }^{9}$.

Secondly, derogations from free competition rules through the application of public service obligations are subject to the logical limit of proportionality: they

\footnotetext{
${ }^{8}$ This evolutionary role is clearly stated in Herman (2006, p. 1): "In an number of European countries, including Austria, public authorities nevertheless felt that the state has the responsibility in providing transport for those who cannot afford or are unfit to drive their own car.... Since the oil crisis of the 1970s ecological concerns also played a role in persuading policy makers to maintain and partly expand ecologically sensible public transport”.

${ }^{9}$ According to Obermann (2007, p. 477): "Not the provision of services as such is characterizing a public service, but the public service obligations imposed on the provision of a service. This means that specific modalities of provision are to be respected within the general interest of public mission perspective. The determination of the specific contents of the public service obligation - and henceforth of the services - needs to rest a political choice and decision process".
} 
are acceptable and justifiable only if and to the extent that they are necessary and effective to fulfill the general interest mission attributed to a service ${ }^{10}$. This stage is influenced by the need to balance the traditional economic approach of market failures with that of burocratic failure, recognizing that even public intervention can bring about inefficiencies and defaults.

Finally, whenever the fulfilment of the public service mission entails a compensation, that is a public disbursement to discharge that mission beyond a purely commercial logic, a cost opportunity assessment should be carried on in order to evaluate the (social) value of the money employed: "When considering whether such obligations should be maintained or extended, it is therefore important to consider the alternative uses to which resources concerned could be put" ${ }^{\prime 11}$.

Figure 1 schematizes the (complex) decisional chain in $\mathrm{LPT}^{12}$ : starting from the wide gamut of factors that influence the definition of the objective function of the transport authority and the recognition of the general interest; passing through the decision about the scope and the contents of the regulatory effort required to meet the general interest (price regulation, access regulation, quality regulation, environmental regulation, financial compensation); and ending with the choice of the organizational form that better suits the previous stages of the chain.

\footnotetext{
10 "However, the rules that they impose must satisfy the conditions laid down in the case law of the Court case law as regards their justification and proportionality. Restrictions on the freedoms of the internal market must be assessed by reference to the objectives pursued by the competent authorities of the Member State concerned and the level of protection which they seek to ensure" (European Commission, 2010 78-79).

11 "Green paper on service of general interest", COM(2003)270, point 9 of the Annex.

${ }^{12}$ Certainly the democratic relationship between local voters and the government should also be added to the chain. To simplify, we assumed that this process takes place without distortions, and that the transport authority acts as a benevolent regulator, interpreting local needs and preferences without alterations and without pursuing own interests.
} 
Figure 1. The decisional chain in LPT services

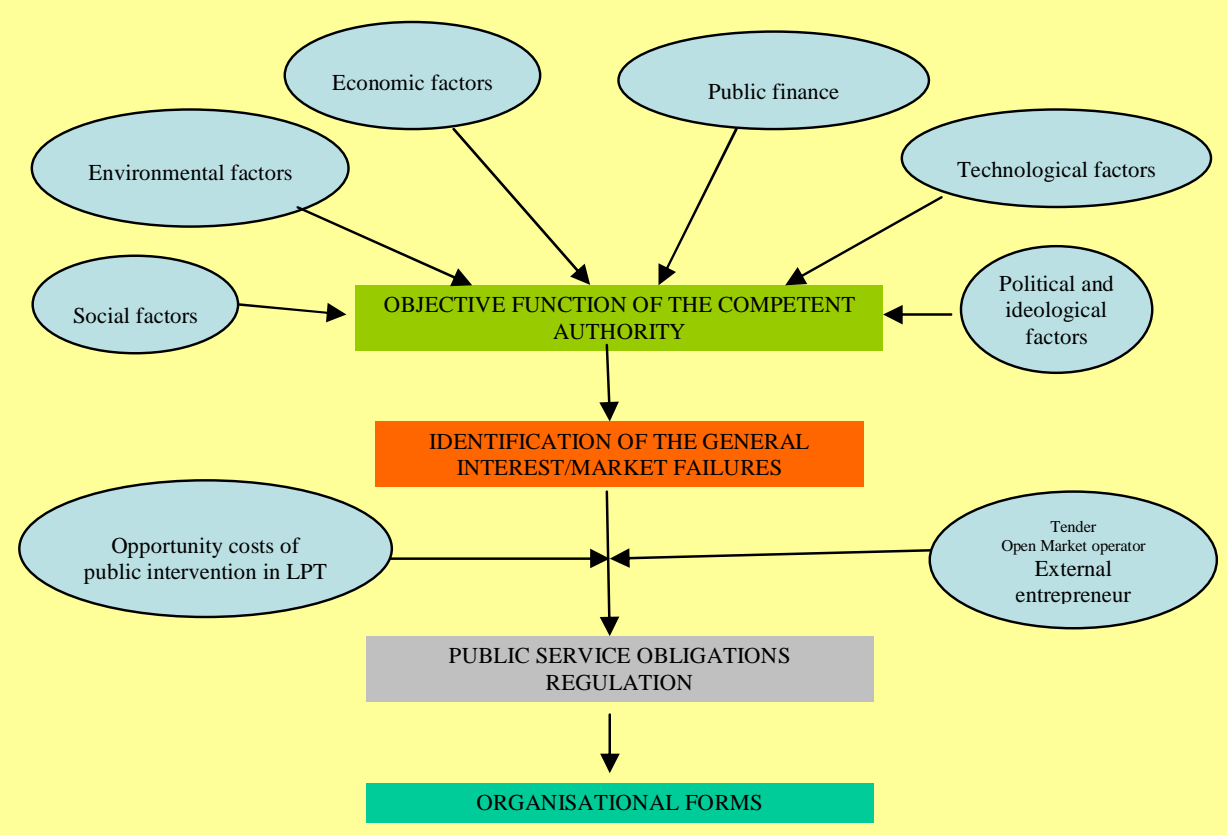

\subsection{Organizational forms and entrepreneurship in public transport}

Organizational forms in LPT can be traced back to two polar apart opportunities: one based on public initiative and the other on market initiative (van de Velde, 1999; van Egmond et al., 2003; Osculati, Zatti, 2005; van de Velde et al., 2008). In public-initiated regimes, those authorities in charge for transport services ${ }^{13}$ have the legal monopoly of initiative (van de Velde et al., 2008) and prescribe (in a more or less detailed way) which services have to be produced. This implies that autonomous market entry is formally forbidden and that transport authorities behave as a monopolistic entrepreneur (van de Velde, 1999): directly producing services (direct public management) or requesting the production of services (public authority as contracting authority). In market-initiated regimes, autonomous market entry is possible, according regulatory checks at the entrance, and leaves the door open to bottom-up contributions from market operators. In this context, the competent authority acts as a licensing authority mainly verifying the compliance of potential market suppliers to legal requisites as well as to social and technical standards - or as an authorising authority, evaluating the desirability of market initiatives according to predetermined

\footnotetext{
${ }^{13}$ According to the EU definition "Competent authorities": i.e. "any public authority or group of public authorities of a Member State or Member States which has the power to intervene in public passenger transport in a given geographical area or any body vested which such authority", Regulation (EC) N. 1379/2007, Article 2.
} 
objectives and strategies, and granting the (more or less exclusive) opportunity to serve the market.

In reality, the dichotomy authority vs. market initiative is in reality idealtipical and concrete models can be characterized by more complex features and even mutual combinations (Fig. 2). Between the left extreme, with a dominant role of public authorities in ownership, planning, and operation, and the right one, with open entry for market operators in a fully deregulated environment, there are in fact several other opportunities, where characteristics can be mixed or where several regimes can even co-exist.

Figure 2. Organizational forms in LPT

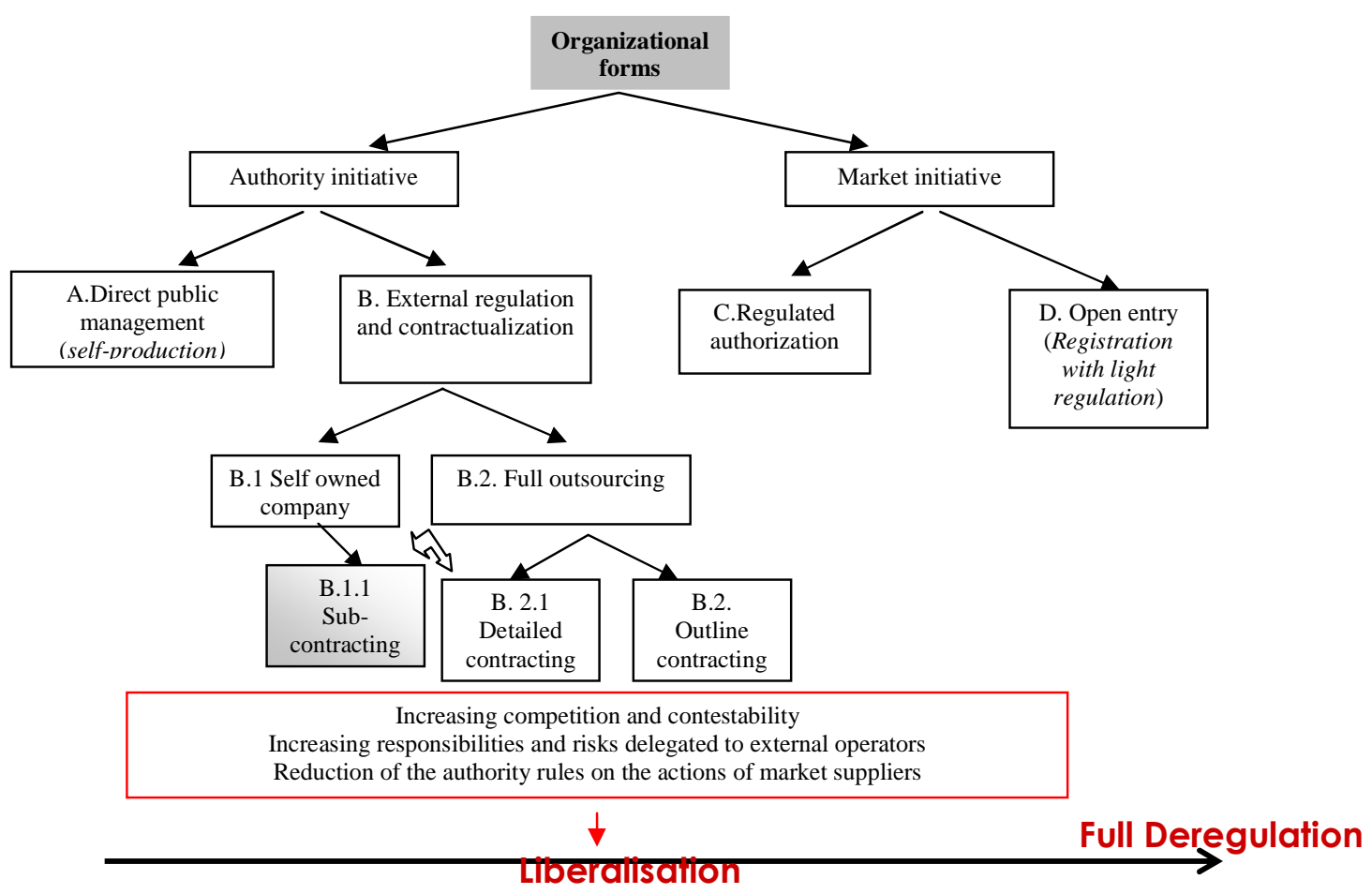

Source: elaborations based on van de Velde (1999).

The key factor to distinguish the different stages included in Figure 2 is the allocation of tasks and responsibilities among the different actors involved. With van de Velde (1999), planning and management of LPT services can be, in fact, divided into several levels of activities which differentiate themselves for the scope of the assumed decisions and the associated planning horizon. According to this view, we can single out:

Strategic level: the general aims of the services are identified together with the broad determination of the resources engaged to pursue those aims. This level includes strategic topics emerging from the objective function of the public authority (environmental and social targets, modal split, territorial accessibility, available budget, etc.), as well as the general description of the main 
characteristics of the services to be provided: area, target groups, territorial coverage, profitability, intermodality, quality standards, etc. This phase is the core of the public intervention chain described in Figure 1 above, since the recognition of the general interest in LPT services necessarily requires that at least some of the strategic levers are kept within the public sphere. Basically, if the strategic decisions are all left to the market, LPT is not considered a service of general interest and the free-market outcome is deemed to be satisfactory even from a social point of view.

Tactical level: decisions are taken on the means to be implemented to reach the general aims defined at the strategic level. This stage translates the latter into detailed service characteristics (i.e. regulatory devices) such as the definition of routes, timetable, tariffs, technical and social standards, labour skills, provision of additional services to passengers.

Operational level: tactical elements are translated into routine management: sales of tickets, advertising, staff management, input purchase, ordinary maintenance, etc. The operational stage is to a large extent an executive stage, where the room of manoeuvring left to the operator is limited by the decisions taken at the tactical one.

The strategic-tactical-operational sequence can be interpreted as a multiple sequence of (potential) principal-agent relationships (van de Velde, 1999; Longva, Osvald, 2010) where the level of the authority intervention and the degree of involvement of external actors can highly differ. The various combinations of the entities in charge of the several decisions/tasks lead to the organizational forms described (from left to right) in Figure 2.

A) "Direct public management-Self production": all the relevant planning and operational decisions are kept within the public administration, through internal departments or organizing entities strictly organic to local authorities. ${ }^{14}$ This model is not based upon true contractual relationships and maintains all the principal-agent relationships within the same organization, through hierarchical control and regulatory acts (laws, statute, labour force enrolment mechanisms, incentives, administrative control and monitoring, etc.). From the budgetary point of view, even if these entities rely on some kind of autonomy and independency, still they are part of the public administration, with their deficit and surplus directly influencing those of the local government they belong to.

B) "External Regulation-Contractualization": the fulfilment of the general interest is entrusted, at a certain point of the decisional chain, to an "external" operator, formally independent from the competent authority. The degree of autonomy of the operator, together with the nature (more or less ample) of the delegation bring about several sub-categorization of this model.

\footnotetext{
14 "Strictly organic" means that local authorities keep the responsibility to define aims and strategic goals, to directly appoint the administrative organs, to approve fundamental acts and to supervise the management.
} 
- B.1) "Self owned company" option: an increasing degree of legal, financial and managerial autonomy is granted to an operator totally (or to a large extent) owned and controlled by the same competent authority responsible for the service. The introduction of contractual relationships between the latter and the operator itself is implemented as the main tool to guarantee transparency and accountability. The transport operator commonly holds the key decisional levers at the tactical and operational level, and can also influence the strategic one, at least discussing and negotiating the general description of the services. The adoption of commercially oriented transformation of the governance structure of the operator (corporatisation), in order to guarantee a wider degree of freedom and manageriality at the tactical and operational level, represents the other key difference with respect to self-production.

The self-owned company option (Figure 2) can be interpreted as an intermediate model between self production and full outsourcing: while, in fact, it relies on some of the basic tools of outsourcing - contractualization, managerial independence, determination of ex-ante lump-sum subsidies -, the ownership link existing between the buyer and the supplier makes this model considerably different from the one based on a relationship with an authentic third party. The more the control is strict and narrow ${ }^{15}$, the more the option is similar to selfproduction; while the attribution of a higher degree of freedom to the company (managerial decisions, enrolment rules, financial relationships) entails a model closer to external regulation, where a new principal-agent rapport emerges.

- B.1.1. "Sub Contracting": in this case the self-owned company, linked to the public authority by a contractual relationship, sub-contracts part of its services to external companies in charge of running only operational tasks (Figure 3), without service planning responsibilities and commercial risk assumption. The company is in charge of an increasing administrative and regulatory role, while it leaves space to independent undertakings at the lower stages of the production chain. Thus, the principal-agent-relationship takes place at the bottom of the service provision process, where simpler tasks have to be carried out and where informational and transaction costs are likely to be lower.

${ }^{15}$ As required, for example, by the in-house definition in the EU-ruling (see below). 
Figure 3. Sub-contracting at the operational phase

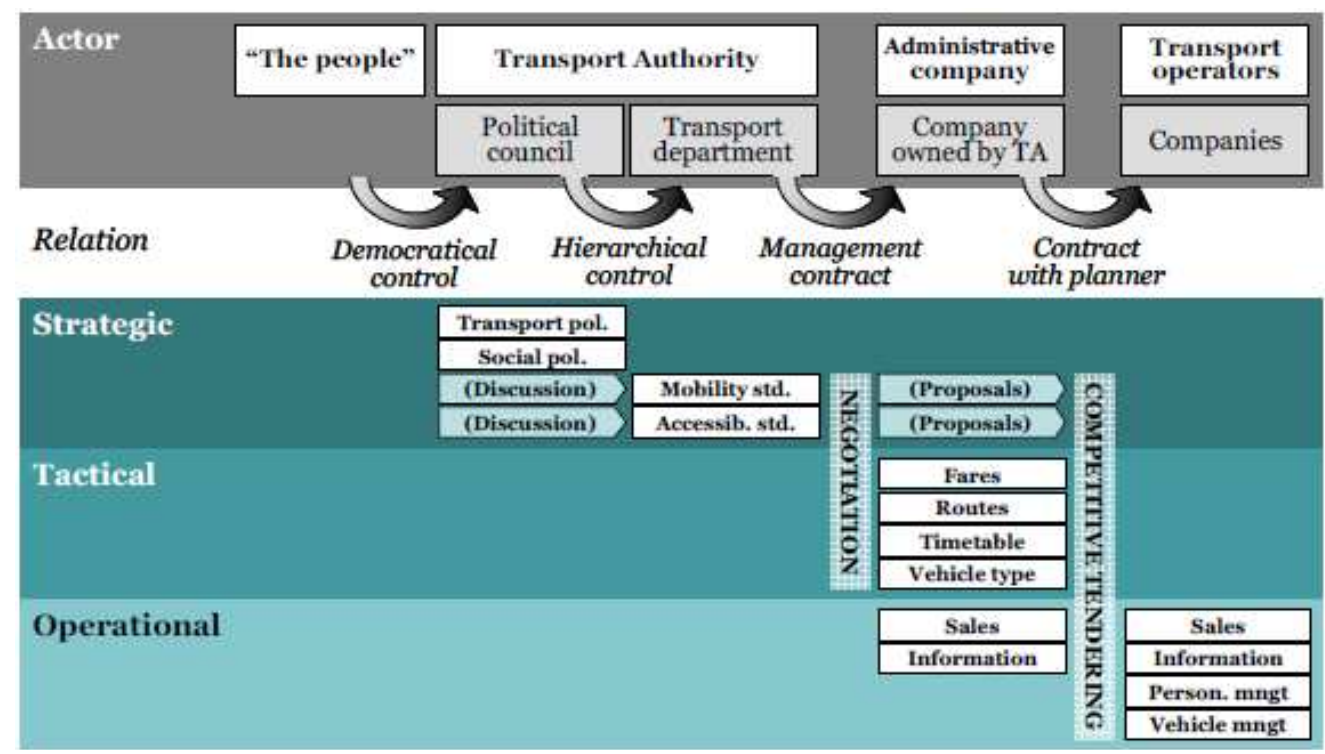

Source: van de Velde et al. (2008).

- B.2) "Full Outsourcing": the contractual relationship takes place with a third party, completely independent from the competent authority. This third party can be a private company or even a public company owned by a government different from the one competent for the service.

The public administration keeps always the strategic decisions, through its transport department or a functional agency, and contracts out, at a certain point of the chain, the realisation of the services planned. The distinctive issue at this stage is the allocation of the decision making at the tactical level (service design) between operator and authority.

- B.2.1. "Detailed contracting": the awarding procedure entails a detailed (closed) specification of the services and tasks required to the supplier in terms of: timetables, routes, tariffs, vehicles, information. It is an organizational form where the regulatory levers (strategic and tactical) are largely in the hands of public authorities, while external operators are involved to perform orders with low discretion. The need to specify in depth service characteristics makes detailed contracting suitable only (or mainly) for simple tasks, i.e. for a single route or small sub-networks, and without requiring large investments or coordination efforts to the operators. At the same time, it leaves the latters fewer optimising opportunities and responsibilities, thus requiring a higher regulatory effort to the public sphere. Where the degree of details of service design is high and the discretion left to the provider is negligible, detailed outsourcing resembles very closely to the "sub-contracting" form (B.1.1), as in both cases the principal-agency relationship occurs only down in the operational phase. 
- B.2.2. "Outline contracting": this model is characterized by the attribution of a higher service-design freedom/responsibility to external agents ${ }^{16}$. Essentially, this is obtained by setting minimum standards and more vague specifications of service design and benefiting operators of more autonomous decision power and opportunity to define (or at least to negotiate) elements characterizing the tactical level (routes, tariffs, quality, etc.). The principalagent relationship occurs at a higher decisional level with respect to detailed delegation, bringing about more challenging monitoring activities.

Outline contracting can be applied to more complex tasks (network or large sub-network contracts) and can exploit the contribution given by the external operator in terms of technical innovation, managerial capacity, risk assumption, etc.; it even suits with longer time periods and with cases where relevant capital investments are required to the supplier. At the same time, the "open" form of the delegation makes it difficult to objectively compare bids and to verify results through fully pre-determined standards. For these reasons, it seems suitable in cases where results are directly dependent on the efforts made by the provider and where the pressure on these efforts can be exerted even by market incentives (customer satisfaction analysis, adequate risk sharing, net cost contracts), able to stimulate operators to realise policy objectives (van de Velde et al., 2008).

C) "Regulated authorisation": in a market initiative regime, competent authorities grant an exclusive or non-exclusive right $^{17}$ to operate specific services to firms that have applied for them. In this model the authorising authority retains (at least partially) a strategic role in defining the social function of collective services, but leaves to market operators the initiative to offer services suitable to comply with the general interest. To play this function the competent administration should define in advance the general aims of LPT services, together with some more or less detailed descriptions about what they expect from operators, and than judge the desirability of proposed market entries according these general principles and strategic aims.

A wide range of possibilities are included under the umbrella of regulated authorisation, depending on how competent authorities handle their two main regulatory tools: the ex ante planning exercise, and the award of more or less exclusivity to the operator. If, on the one hand, a well established local transport plan exists and new entries are strictly ruled by the awarding of temporary exclusive rights, regulated authorisation shows many similarities with the models of external regulation included in the authority initiative regimes. On the contrary, if service goals and characteristics are not well outlined in advance and

\footnotetext{
${ }^{16}$ This can be also referred to as "open delegation" (Falcone, Castelfranchi, 1999 p. 26), given that the agent is supposed to use its knowledge, intelligence, and ability to exert some degree of discretion.

${ }^{17}$ When an exclusive authorisation is granted, other operators are excluded from providing the same services under the same conditions.
} 
the degree of protection against competition accorded to authorised operators is weak or null, this model becomes closer to more de-regulated regimes.

D) "Open entry": transport operators autonomously offer services on the market according to their commercial profitability, without the need to fulfil predefined social aims and without receiving exclusive rights. Public authorities, on the other hand, have only the role (licensing authority) of assessing the compliance of potential operators with minimal technical/social standards and legal rules ${ }^{18}$ (van de Velde et al., 2008). A completely open entry regime entails that no serious market failures are recognized in collective transport services or that it is deemed that a more intrusive form of public intervention can bring about more costs than benefits.

Actually, a fully deregulated collective transport system is to be intended mainly as an idealtipical (right) extreme (Fig. 2). Real organizational forms, in fact, even in regimes based mainly on market initiative, retain at least some forms of political guidance and influence apart from legal licensing. In particular, public authorities can influence market outcome through the following levers (van de Velde, 1999):

- Requiring licensing standards higher than those established by law: safety, passenger comfort, quality, vehicle accessibility, on-board information, environmental performance of vehicles, equal right promotion, etc.

- Subsidising potential operators or users in order to influence their behaviour and to make the market outcome closer to the social optimum. Subsidies may be given to rebate fares for specific target groups, to provide or develop shared infrastructures or functions than can improve the overall quality of services (information systems, service and ticketing coordination, bus stops, traffic priority systems, etc.), to reduce fuel duties for undertakings, etc. All these provisions stimulate an increase in the supply/demand beyond the simple commercial calculation, thus reaching different market equilibrium than would have otherwise emerged (van de Velde, 1999).

Both additional standards and compensations apply to all potential providers and therefore do not obstacle or reduce the competitive threat neither the innovative contribution typical of bottom-up regimes.

- Providing (non profitable) services in addition to those supplied by the autonomous market initiative in order to better meet the transport social and policy aims. The realisation of such services can be secured directly by the public authority or contracted out. With this option, the market initiated regime coexists with a more or less ample market branch where the competent authority still acts as the planner of LPT services as in public initiated regimes.

\footnotetext{
${ }^{18}$ It is worth noting how this role is also common to all the other market regimes. That means that only licensed operators can apply for contracts both in authority initiated and in private initiated regimes.
} 
Through higher licensing (or authorisation) standards, horizontal subsidies and the possibility to create a proper supply, public authorities acknowledge some forms of general interest in LPT services and (re)acquire a strategic role in influencing the market outcome. Thus, the more the three levers are exploited, the more the actual organizational form will be far (and to the left) from the pure market initiative model described in Figure 2.

To conclude this brief methodological premise, three horizontal issues, affecting almost all the organizational regimes described above, need to be considered with more detail.

The first concerns the distinction between internal regulation and external regulation in governing public service provision. A key decision in market organizations is in fact represented by the choice between keeping the whole production chain within the framework of administrative activity and hierarchical control, and that of progressively leaving room of manoeuvring to external operators, more or less constrained by contractual and/or regulatory limits. The scheme described in Figure 2 shows that the internal vs external alternative can emerge at different levels of the decisional chain, according to how much open is the delegation of responsibilities granted to market suppliers. As a whole, the level of public intervention decreases form the left to the right, until an extreme where only minimum forms of soft regulation are enacted.

Both internal and external regulation have advantages and drawbacks that need to be well evaluated in advance, taking into consideration the objective function of the government and the specific characteristics of the service to be offered. In this perspective, the economic analysis suggests that factors such as market and non market failures, budgetary constraints, production vs. transaction costs, certainty of results, complexity of tasks and objects of contracts, frequency of transaction, measurability of results, and the degree of market contestability can guide public authorities to decide if and how much to delegate to the market or if and how much provide directly (Obermann, 2007; Johansson, 2008). It follows that organizational choices on the left should be the result of decisional process where the (social) costs of a deeper external involvement (market failures, cream skimming, asymmetric information, transaction costs, etc.) are evaluated to be too high with respect to the potential benefits (production efficiency, innovation, manageriality, public funds saving, etc.). On the other hand, the progressive shifting towards the right end could and should be the effect of an evolving environment, where technical, social and legal forces trigger a higher degree of market involvement.

The second horizontal topic regards the use of contracts. Where some kind of outsourcing is exploited, contracts have the key function to describe the separation of roles and to define responsibility and risk allocation between the competent authority and the operator. It is therefore through the delineation of the contractual delegation and the type of risk sharing (box 1) that different 
market regimes described in Figure 2 come out. Contract design and contents (length, public service compensation, tariffs, asset ownership, revenue and cost risks, and quality standards) are the key regulatory device to rule these aspects and they should be developed in a consistent way with respect to a number of external and internal factors: legal framework, budgetary constraints, public authority expertise, social and policy goals, etc.

\section{Box 1. Contractual forms and risk allocation in the delegation/outsourcing of local public transport services}

There are three major risks linked to local public transport management: revenue risks (passengers paying tickets are below expectation), operating cost risk (maintenance costs, fuel price, traffic related costs, etc.), and investment risk (purchasing and replacing assets). Revenue risk is the risk associated to demand fluctuation, while production risk (operating+investment) is the risk associated to production costs of a fixed production quantity, independent of the amount of passengers.

Risk can be shared in different ways between a transport authority and a transport operator. A common way to represent the possible arrangements is through the following idealtipical contractual forms:

Management contracts. The authority bears all the risks: commercial/revenue and production costs. The operator involvement is limited to the professional management of operations on behalf of the Authority for a fixed, negotiated period of time and for an agreed price, independent from the achievements. It corresponds to a form of cost plus contract.

Gross cost contracts. The operating cost risk is usually transferred to the operator whilst the revenue risk stays with the authority. Under gross cost contracts, all revenues (coming from fares and other sources) are transferred to the Authority and the risks absorbed by the operator are confined to those associated with the operation costs. With gross cost contracts, the operator benefits from costs savings but has no direct incentive to increase patronage neither to be duly diligent in revenue collection. It is a variant of fixed-price contracts.

Net cost contracts. The operator bears the cost risk and the revenue risk. The operator is normally entitled to all revenues (coming from fares and other sources) and therefore bears additional risks. These typically concern disturbances to traffic, revenue fluctuations, changes to the regulatory regimes, inability to limit private traffic, etc. It is another variant of fixed-price contracts.

Under management contracts the authority commonly retains also the investment risk - i.e. the authority has the ownership and control of all stations, depots, vehicles and other infrastructures and, therefore, carries the risk on the property and value of assets -; in gross cost and net cost contracts investment risk can be borne either by the authority or by the provider. In the latter case, the authority contracts with an outside organization to provide (or, in the case of existing systems, to maintain or upgrade) the majority of the fixed and even moveable assets and, simultaneously, to provide services according to pre-defined qualitative and quantitative standards. This form is commonly referred to as net cost contracts with investments (NCCI) and represents the contractual form through which the operator is given the highest degree of risk, to be covered by commercial revenues and by other transfers granted by the administration.

\begin{tabular}{|l|c|c|c|}
\hline \multirow{2}{*}{$\begin{array}{l}\text { Contract } \\
\text { Type }\end{array}$} & \multicolumn{3}{|c|}{ Bearer of Risk: } \\
\cline { 2 - 4 } Management & Cost Risk & Revenue Risk & Investment Risk \\
\hline Gross Cost & Operator & Authority & Authority \\
\hline Net Cost & Operator & Operator & $\begin{array}{c}\text { Authority or } \\
\text { Operator }\end{array}$ \\
\hline NCCI & Operator & Operator & Operator \\
\hline
\end{tabular}

Source: Colin Buchanan and Partners (2003a).

Typically, the pure contractual forms described above are rare, while commonly both revenue and costs risks are shared through apposite arrangements and incentives/disincentives. For example, under a net cost contract with risk sharing arrangement, the operator might be provided with a subsidy if patronage falls below a specified level 
and might, in return, agree to return to the Authority all, or part, of the revenue obtained above an agreed, upperspecified threshold. At the same time, in a gross contract regime, operators can be entitled to retain a share of additional revenue achieved above a certain target level.

Therefore, the observed contractual forms must be evaluated according to how much they are similar to the other options described above.

The allocation of the commercial risk represents the key distinguishing feature of another essential classification of contractual arrangements between the competent authority and the operator:

Service concessions contracts: when the contractor is paid mostly by users and, consequently, takes at least part of the commercial risk.

Public services contracts: when most of the operator's remuneration comes from the public competent authority so that the former's assumption of the commercial risk is negligible.

This classification acquires a relevant role since different normative regimes normally apply to the two different forms (see below par. 3.2 for the EU case).

Finally, the role of competitive procedures has to be addressed. In the framework described in Figure 2, competitive tendering is not to be intended as an autonomous organizational form of service provision, but mostly as a selecting mechanism in the context of outsourcing (van de Velde, 1999), implemented to contract out a more or less extensive share of functions and services. It is a (optional or obligatory ${ }^{19}$ ) tool to play the regulatory role and to select external providers in an optimal way. Accordingly, it is compatible, on the one hand, with all the organizational forms where the role of the competent authority and the operator no longer coincide ( $\neq$ self-production) and, on the other, with those where the competent public authority retains some powers to define the characteristics of the services required from the market ${ }^{20}(\neq$ fully deregulated systems).

Being franchising essentially a method to outsource, it can be applied to different steps of the production chain, with different degree of complexity: it can be exploited to buy a simple function or task (cleaning, ticketing, staffing, IT management); or to buy services for a limited portion of the LPT network (route tendering), or to award services to cover the whole urban network (network tendering); or even to get both assets and service provisions.

The degree of complexity, related to the degree of "openness" of the delegation to the agent, has (or at least should have) also important effects on the choice of the characteristics of tenders and of the selecting mechanisms (Colin Buchanan and Partners, 2003a; Amaral et al., 2009; Hensher, Stanley, 2010):

- Bids based only (or predominantly) on price, in fact, normally require a full (very detailed) specification of the services/functions to be offered. For this reason, they reduce the role of subjective judgements in the evaluation phase while, at the same time, can be more realistically applied to small size and simple-task contracts (e.g. route contracts). Even if price-based

\footnotetext{
${ }^{19}$ Some contractual forms are subject to obligatory competitive tendering under EU and national rules.

${ }^{20}$ The term "regulated competition" clarifies this situation: since it makes reference to a situation where some form of contestability is introduced ( $\neq$ internal production), but in a regulated way ( $\neq$ full deregulation).
} 
auctions can be used for either management, gross or net cost contracts, the very detailed nature of the delegation makes the assumption of revenue risks (ie. net cost contracts) problematic for the bidders.

- Bids based on some combination of price and quality leave the opportunity to tenderers to propose higher quantitative or qualitative levels of services. This form of tender increases the role of subjective discretion in the selection process and even the opportunity to leave space to some kind of negotiations with one or more pre-selected tenderers in order to determine the detailed contractual terms. Multicriteria selections can be more realistically applied even to complex tasks and larger networks and commonly induce a lower degree of ex ante competition because of the complex and more vague nature of the attribution process. For the same reason, they make desirable that some form of continuous market incentive (i.e. revenue risk assumption) is allocated to the operator in the implementation phase of the contract.

- Bids based only on the quality of services further increase the room for bottom-up involvement and, as well, the necessity to have an effective expost monitoring activity. For the same reason they can make the use of net cost contracts more attractive to self-enforce the fulfilment of contracts.

The implementation of competitive procedures (the so-called limited or controlled or regulated competition) is found to bring about rather successful outcomes in terms of production efficiency and costs reduction (ISOTOPE, 1997; ECMT, 2002; Colin Buchanan and Partners, 2003a; van Egmond et al., 2003; Nash, Wolanski 2010), thanks to the introduction of some form of market pressure on operators to get contracts. At the same time, it is expected to entail higher transaction costs, being time and resource-consuming for both the tendering authority and the applicants (Anderson et al., 2007; Amaral, 2008; Hensher, Stanley, 2010), and to require relevant monitoring and controlling efforts for measuring the correspondence of ex-post results to the established parameters.

The recourse to regulated competition should therefore be consequent to an intentional evaluation of these expected benefits and costs. This comes out to be more and more relevant in a legal framework characterized by the obligation to adopt tendering procedures to outsource services since competition becomes a necessary step when external-regulation is preferred.

\subsection{Liberalization as a multidimensional (and complex) process}

The organizational forms outlined in the previous section need to be interpreted in a dynamic way. While, in fact, it is actually problematic to trace back observed models to those described in Figure 2, it's easier and even more 
significant to evaluate in what direction (and to what extent) the move of national/regional/local systems takes place.

Accordingly, the spreading of municipal socialism in Europe from the end of the $19^{\text {th }}$ century to the early $20^{\text {th }}$ has been largely explained as a process of reaction to market failures (Millward, 2010), through which local administrations progressively supplanted the market and behaved as an entrepreneur in designing and managing many local public services (including collective transportation). The disillusionment with private initiated regimes gave way in most countries to direct self-production as the dominant form of regulation, with the emerging of a model where public authorities governed the whole process of service provision, thus converging to the option in the left extreme of Figure 2.

Starting from this almost generalised background, new organizational forms and market models progressively came out in the last two decades of the $20^{\text {th }}$ century, following exactly the opposite course. Bureaucratic failures and other driving forces (box 2), in fact, triggered de-integration and a changing regulatory environment. These forces contributed to modify both the objective function of the public authority, and thus the nature of the general interest, and the regulatory approach to pursue that interest. The principal aim of this development has been to recover efficiency and to cut production costs, in order to reduce public funding and/or to permit the expansion of resources directed to collective services and infrastructures, without increasing the burden on the already meagre public finances (Osculati, Zatti, 2005; Roy, Yvrand-Billon, 2006; Bianco, Sestito, 2010).

\section{Box 2. Main driving forces of the changing regulatory environment in European SGEIs}

Technological and social changes. In some network services, technological and social progress brought about the reconsideration of the extent of market failures, opening up the path for a more market oriented approaches.

Non market failures ${ }^{21}$. The poor performance of public providers (high costs, low ability of collective services to fulfil their social role, poor quality, high fragmentation) and the emergence of bureaucratic failures (political influence, low or absent incentives, low customer attention, low degree of specialization, etc.) stimulated the research of alternative regulatory approaches, with a lower degree of direct involvement of the public authority.

Budget tightening. The increasing cost-opportunity of public funds, influenced by the macro-budgetary constraints established at the EU level, made attractive to lower government spending and to carry out privatizations.

Ideological and theoretical background. The development and strengthening of the influence of new economic and administrative theories - Leviathan, rational/public choice, New public management - called for a wide process of public service restructuring, mainly based on more market oriented mechanisms of governance and regulation: the separation of politics from administration, placing the emphasis on the citizen as a client, strategic planning and management, contracting out, competitive tendering, measurement of results, public service management flexibility, use of innovative accounting methods, personnel management based on wage incentives, use of full cost recovery tariffs.

Europeisation. Beginning with the Single Act (1987), the Community level has intervened in an increasingly intrusive manner in the local service sector, with the primary intention of ensuring conditions of competitiveness and free market. This process has been characterized by an important boost towards the full maturity of the single market and the full attainment of the four great freedoms of movement, calling into question the traditional national organizational models.

${ }^{21}$ As synthesized by Hermann et al. (2007, p. 16): "State ownership did not prevent public services from being under-funded and of poor quality". 
The liberalization of public service provision - i.e. the first distinguishing aspect of the "dominant paradigm" we want to discuss - can be regarded in this general background as a composite evolution with respect to a starting point characterized by the overseeing of the whole process of service provision by public authorities and the almost complete absence of market pressure along the different stages of the production chain.

This process can be seen as a multi-dimensional course, characterized by four main directions of change (Figure 4):

A) Increasing splitting between planning and operations, through the adoption of ex-ante contractual arrangements and the budgetary and legal separation of operators from the competent political authority. This separation aims at increasing transparency of management activities and production costs and, accordingly, accountability on qualitative and financial results (Longva, Osland, 2010). It could/should also represent a necessary step to stimulate some form of competitive pressure on providers, through comparisons with similar firms operating in similar circumstances (yardstick competition), or through the successive development of tendering procedures for services awarding. Separation can be seen as a conditio sine qua non of liberalization, without which even the following steps can hardly take place in an effective way ${ }^{22}$.

B) Progressive reduction of authority rules on the actions of market suppliers. The development of liberalization is influenced by the degree of autonomy and responsibility granted to the external operators to determine characteristics and design of the services. The higher the number of activities delegated to the operators, the higher is the extent of liberalization and, hence, the decrease in the grade of vertical integration. For example, with a low level of de-integration, operators can be involved only in simple activities related to marketing, information to passengers, IT management or single route provision; with a stronger push towards liberalization, they play a key role in suggesting and/or deciding the key tactical solutions for service provision (routes, schedule, fares, quality standards, etc.). In a fully deregulated market they can freely define what to produce, once normative standards are respected.

C) Increasing allocation of risks to the external operator. A more liberalized market has to be considered as an organizational model where operators assume an increasing share of production and commercial risks. This view is

\footnotetext{
${ }^{22}$ In the same direction OECD (2005, p. 18): "The state often plays a dual role of market regulator and owner of state-owned enterprises with commercial operations, particularly in the newly deregulated and often partially privatised network industries. Whenever this is the case, the state is at the same time a major market player and an arbitrator. Full administrative separation of responsibilities for ownership and market regulation is therefore a fundamental prerequisite for creating a level playing field for state-owned enterprises and private companies and for avoiding distortion of competition".
} 
schematically represented by the typical contract forms already described in box $1^{23}$, even if it can be more realistically assumed that many intermediate forms of risk sharing can be designed through contractual arrangements. Risk allocation has to be seen more as a continuum rather than a choice characterized by rigid divisions (see also Figure 5 below).

D) Increasing degree of market contestability ${ }^{24}$, through which incumbent companies are threatened by potential entrants, causing efficiency enhancing effects. Accordingly, a more liberalized market is certainly a market where (exante) more pro-competitive procedures are implemented to award functions/services, and even where other (ex-post) results are confirmed: mobility of providers, rate of switching, number of participants to bids, costs reduction, etc.

In a fully deregulated market the four elements are for the most part developed: complete separation of roles (production by market operators / soft regulation by the public authority), maximum degree of autonomy for external operators, full assumption of operative and commercial risks, no protection against new entrants. On the contrary, none is found in self-production regimes. Between these two extremes the degree of development and the combination of all the aspects can vary a lot from case to case, bringing about the overall assessment of what we intend for liberalization. Consequently, there could be models where one or two dimensions are highly developed, while others are less or modestly come into being, making the overall evaluation more complex and ambiguous.

\footnotetext{
${ }^{23}$ Where management contracts imply a minimum level of risk, net cost contracts (and service concessions) create a rather high level of risk; and gross cost contracts represent an intermediate option.

${ }^{24}$ This dimension is for example predominant in the context of the PIQUE project: "Liberalisation aims at building competitive market structures, in which many providers compete with each other in an integrated and easily accessible market" (Flecker et al., 2009, p. 7) or. "Liberalisation, above all, is about the introduction of competition in formerly protected markets" (Brandt, Shulten, 2008, p. 1).
} 
Figure 4. The 4 dimensions of liberalization

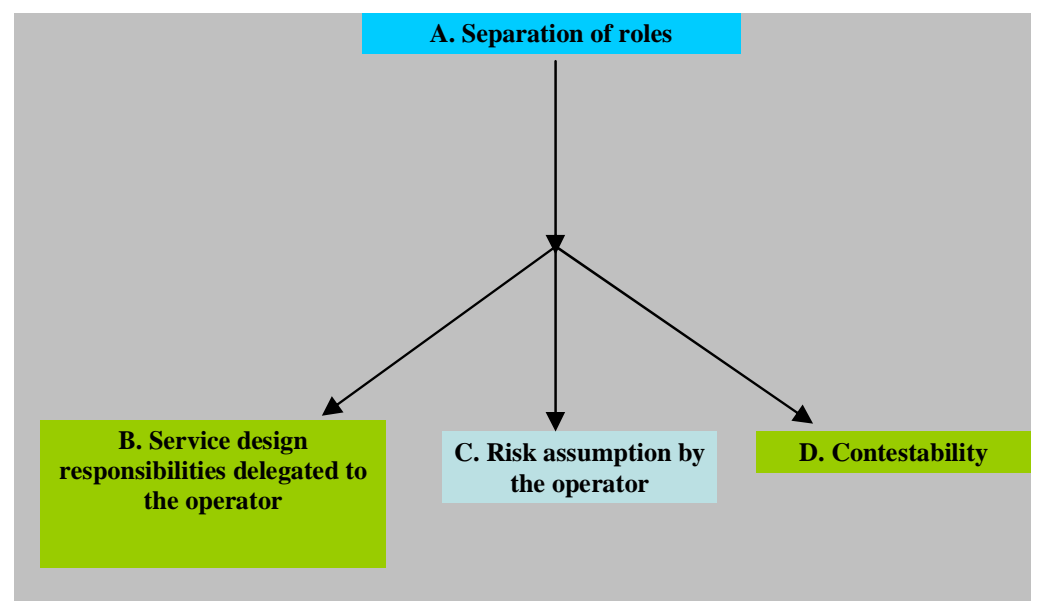

The four dimensions of Figure 4 are not wholly independent and at least three relevant reciprocal relationships must be carefully taken into considerations.

The first regards the higher hierarchic position to be given to separation. When a high degree of independence (legal, budgetary, political) between the competent authority and the operator is not established, it is actually unlikely that accountability, risk sharing and market contestability can develop in an effective and transparent way. If one or more market operators are tied to the local competent authority by financial or political links, in fact, the effective allocation of service responsibilities and risk assumption may turn out to be opaque, so as the proper competitive comparison among potential suppliers is likely to result altered.

The second regards dimensions $\mathrm{B}$ and $\mathrm{C}$, since a correct balance between responsibilities and incentives included in the contracts should be pursued (Colin Buchanan and Partners, 2003a; van de Velde et al., 2008; Nash, Wolanski, 2010) ${ }^{25}$. The attribution of an increasing level of risk to the operator along the continuum described in the upper part of Figure 5 can be consistent only within organizational models where operators are given extensive service design responsibilities to influence passenger demand (lower part of Figure 5). Accordingly, if providers are granted a considerable freedom in service design (open delegation), it is preferable they are stimulated on service quality and outcomes (even) through more incentivizing and risk-assuming contractual arrangements. Along with this view, it is also not recommended to make the operator born risks on outcomes that depend substantially on actions falling under the authority control (van de Velde et al., 2008). This is particularly relevant in LPT, where typical "public" measures such as those pertaining

\footnotetext{
${ }^{25}$ Both the mentioned reports prepared for the EU Commission underline this aspect: "it is recommended to rebalance between the allocation of risk and the allocation of responsibilities" (van de Velde et al, 2008, p. 53) and "if operators are expected to bear some risk (under a Net Cost or NCCI contract) they may reasonably expect to have appropriate input to the planning function" (Colin Buchanan and Partners, 2003a, p. 2-15).
} 
access controls, parking and road pricing, land-use planning, parking supply, etc., may substantially influence the profitability of contractual relationships.

Figure 5. Service design and risk allocation

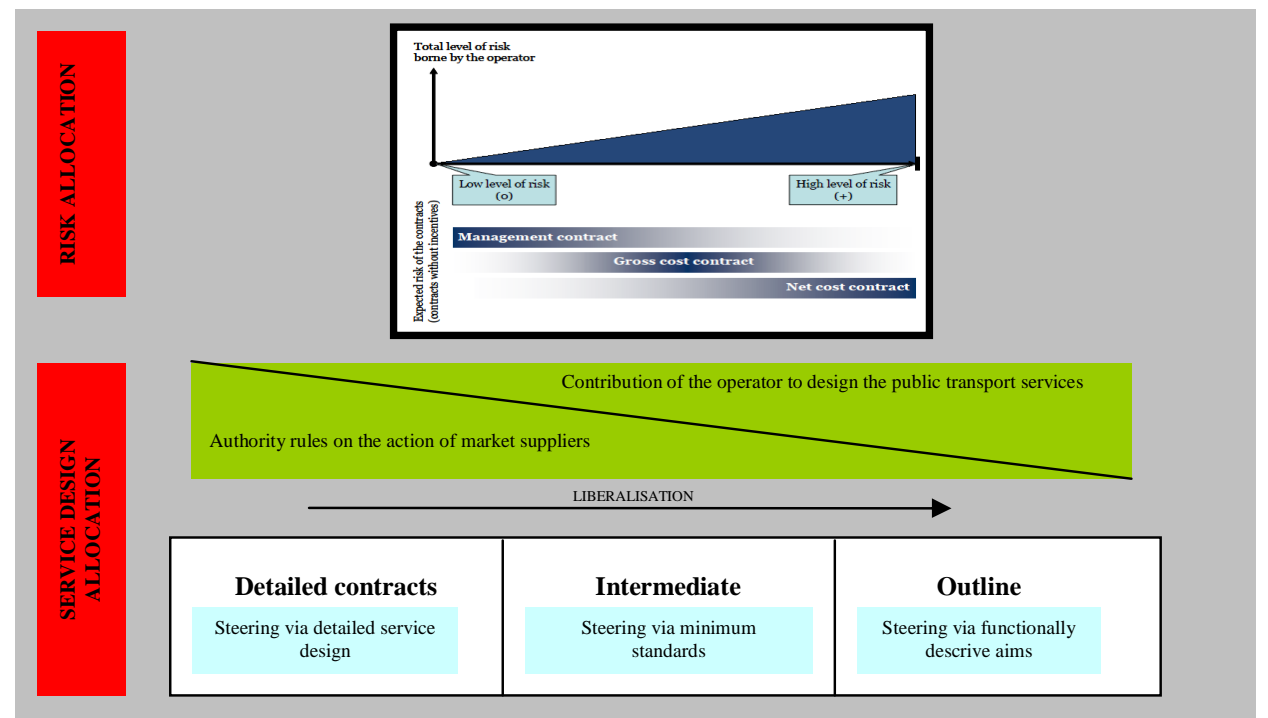

Source: adaptations on van de Velde et al. (2008).

Thirdly, the influence of dimensions $\mathrm{B} / \mathrm{C}$ on the degree of contestability $\mathrm{D}$ needs to be taken into account, as several trade-offs may emerge. Broadly speaking, in fact, the attribution of larger responsibilities and risks to the operator (two factors enhancing liberalization) can limit the number of bidders and hence the competitive pressure on tenderers to diminish costs and increase quality ${ }^{26}$ (thus conflicting with the fourth dimension of liberalization). If, therefore, large-area contracts, operators' asset ownership, long-term contracts and higher degrees of risk assumption raise the potential contribution given by the market to service design and management, the "discipline" of competition in terms of cost reduction and opportunity to compare many alternatives can be lowered. The search for a correct equilibrium between these, potentially conflicting, alternatives represents therefore one of the key features of the liberalization process.

As a conclusive remark, it has to be highlighted how the process of liberalization is far from indicating disinterest by the State and local governments in the conditions of the public services, neither it can be assumed to entail a decline or simplification of the role of policy makers. In fact, but for fully deregulated markets, public service obligations, contracts design and public authorities' capacity for expertise and control acquire a crucial role in determining the outcome of "liberalized" markets (Amaral, 2008; Nash, Wolanski, 2010).

\footnotetext{
${ }^{26}$ Beck (2010, p. 189) finds for example that "results indicate that the revenue risk does have a negative influence on the level of competition".
} 
If liberalization has to be seen as a new model of sharing tasks and responsibilities between internal and external operators (de-integration), public services obligations and public service contracts become fundamental means to:

- make the operator's view converge towards the general/public interest;

- guarantee the separation of roles;

- describe service design responsibility;

- define risk allocation;

- develop ex post means of checking whether the obligations of the parties have been fulfilled or not.

Thus, contractual terms and related awarding mechanisms determine in a clear manner the success of the partnership between the regulatory authority and the agent and the different degree of maturity attained by the four dimensions of liberalization. It follows also that the development (and the success) of the process of de-integration is strictly influenced by the local authority capacity to implement a high powered incentive scheme on the transport operator's performance (Amaral, 2008). Contract design, the determination of awarding criteria, attribution processes, contract adaptation, execution, management and monitoring are the cornerstones of this scheme: tricky tasks that tend to become more complex with the enhancement of the external operators' degree of autonomy.

The equation liberalization=simplification of the public role seems therefore far from reality and needs to be verified with care through the empirical analysis.

\subsection{Privatization as an opportunity}

Privatization entails a shift in the ownership structure of providers (Flecker et al., 2009).

As in the case of liberalization, privatization can be interpreted more as a dynamic and gradual process rather than a yes/not option. It is in fact implausible to think about a radical shift from an entirely public to an entirely private sectoral ownership structure, while smooth and non linear trends are more likely.

In particular, three different steps can be singled out:

- Formal privatization (corporatization): i.e. the shift in the legal form of public-service companies from autonomous public companies to companies ruled under private law (join-stock-companies, limited-liability companies) but still owned by public governments.

- Mixed ownership: i.e. companies with both public and private shareholders, but with the predominance of public control.

- Mainly private ownership: i.e. companies completely or predominantly shared and controlled by private agents. 
Given that EU formally does not concern itself with the question of ownership ${ }^{27}$ and provides for equal treatment between public and private enterprises (Bauby, Similie, 2010), the form and the degree of privatization shall be interpreted as opportunities to improve the outcome of the changing regulatory environment. Privatization can emerge as a choice to be exploited within the different organizational forms, once that benefits and costs are evaluated.

Schematically, and without any claim of exhaustiveness, the principal benefits commonly coupled with privatization can be traced back to the following items.

Firstly, privatization is supposed to increase the internal efficiency of providers and, thus, to lower the operating costs of services with respect to public companies (Roy, Yvrand Billon, 2007; Amaral, 2008). Although results on this subject are highly uncertain and debated ${ }^{28}$, the supposed higher efficiency of private companies is traced back to two main reasons: the clearer and more focused definition of objectives ${ }^{29}$ and the wider presence of internal and external incentives for managers and workers ${ }^{30}$ (Roy, Yvrand Billon, 2007; Mattisson, Thomasson, 2007; Amaral, 2008). Moreover, when private participation is necessarily associated with ex ante tendering procedures, the competitive pressure reinforces the possibility that private partnership improves production efficiency.

Secondly, privatization strengthens the separation of roles and interests between regulators and providers and contributes to the credibility of service contracts and budget constraints. It represents, from this point of view, a factor underpinning the basic dimension of liberalization described in Figure 4.

Thirdly, it contributes to reduce public debt and to free up resources for other public functions, becoming more attractive in stricter budget constraints periods. On the other hand, privatization creates potential conflicts between the commercial and other objectives of the external operator and the general interest pursued by the public authority. Thus, the presence of a more clear objective

\footnotetext{
${ }^{27}$ Art. 345 TFEU: "The Treaties shall in no way prejudice the rules in Member States governing the system of property ownership".

${ }^{28}$ According to Bognetti and Obermann (2008, p. 467-468) "Several empirical studies have been conducted to establish whether private enterprise is more efficient than public enterprise, but on the whole we think that a firm conclusion cannot be reached yet" and "as far as microeconomic performance is concerned the studies of the effect of ownership on performance are hardly conclusive and seem to give more weight to the type of regulation adopted and to existence of real competition".

${ }^{29}$ In public firms political, social, environmental, redistributive objectives can bring about a more ambiguous definition of the objective function and, as a consequence, lead to higher management discretion and lower performances. In other terms: "The overall aim of profit in a commercial sector has no obvious counterpart in analysis of public sector strategy" (Mattisson, Thomasson, 2007, p. 442).

${ }^{30}$ Incentives can be represented by pay-offs based on results, budget constraints, pressure exerted by the financial markets or by the market for corporate control, and a high degree of financial and managerial transparency.
} 
function within private firms, that represents a stimulus in terms of production efficiency, brings about pitfalls in terms of allocative efficiency. This circumstance further increases the need for regulation to tackle the implicit trade-offs, and, accordingly, entails higher transaction costs and specific expertise.

As a whole, the recourse to private management has positive effects when production cost advantages outweigh transaction costs and the risk of opportunistic behaviors; while can be counterproductive when the opposite occurs.

\section{The EU Legal framework}

\subsection{The process of Europeanisation in Local public transport: an historical overview}

The Europeanisation of public services is frequently considered as the "backbone of changes" taking place in all Member States of the EU (Bauby, Similie, 2010, p. 36). The concept refers to the progressive transition from the traditional national framework of definition and organization of services of general interest (SGIs) to the European level. While, in fact, public utilities have been de facto initially excluded by the treaties (Bognetti, Obermann, 2008), the boost towards the full maturity of the single market and the full attainment of the four great freedoms of movement, brought about by the Single Act of 1986, progressively involved even the field of SGIs, both through secondary law (directives and regulation) or the decisions of the European Court of Justice to fill voids of the secondary law itself (Bauby, Similie, 2010).

The main elements of this changing environment can be summarised as follow.

Firstly, it is established that derogations from competition rules are subject to the general principles of the EC Treaty regarding freedom of establishment and freedom to provide services (Articles 49 and 56 of the TFEU), that encompass in particular (European Commission, 2000) the principles of equality of treatment, transparency, proportionality and mutual recognition. These provisions are essentially aimed at protecting the interests of operators established in a Member

State that wish to offer goods or services to competent authorities established in another Member State. To that end, they want to avoid both the risk of preference being given to national applicants whenever a contract is awarded by the contracting authorities and the possibility that a body governed by public law may be influenced by considerations other than economic ones (European Commission, 2004). The proportionality principle implies also that organizational forms different from open market are acceptable only if and to 
the extent that they are strictly necessary to fulfil the general interest mission attributed to the service.

Secondly, it is recognized that the progressive opening-up of the market and the application of the general rules on competition to SGIs can be accompanied by measures to protect the general interest ${ }^{31}$ (European Commission, 2003). The notion of "universal service" thus began to take shape in telecommunications, postal services and electricity, and that of "public service obligations" (PSO) in energy and transport ${ }^{32}$. These obligations refer to the possibility for public authorities (at the community, national or local level) to impose specific requirements on the provider, even departing from the Treaty rules on market competition, in order to ensure that certain general interests are met. In the transport sector the concept has been further detailed by regulation 1191/69 that laid down the rules on the obligations assumed by undertakings for the operation of public transport services (Jaspers, 2009). According to article 1-3, the regulation permits the establishment of public service contracts with transport undertakings "in order to ensure adequate transport services which in particular take into account social and environmental factors and town and country planning or with a view to offering particular fares to certain categories of passengers". Concerning the scope of public service obligation, the regulation describes three main typologies (Goldberg, 2006; Jaspers, 2009): i) the obligation to operate, that is the obligation for operators to ensure pre-defined transport routes satisfying fixed standards of continuity, regularity and capacity; ii) the obligation to carry, that is the obligation to accept and carry passengers or goods responding to certain prerequisites; iii) fare obligation, meaning those obligations established by competent authorities to apply certain rates for certain categories of passengers. A relevant role is therefore preserved for public authorities, as they have the responsibility to define what they consider to be a general interest, to impose public service obligations and, finally, to verify that operators accomplish the public service missions entrusted to them.

Thirdly, the European legislation allows providers of services of SGIs to be compensated for the extra cost of fulfilling the assigned public service mission. In particular, article 93 of TFEU gives Member States the right to grant state aid to transport operators if they meet the needs of coordination or if they represent reimbursement for the discharge of certain obligations inherent the concept of public service. Art. 93 represents a form of lex specialis for the transport sector

\footnotetext{
${ }^{31}$ Specifically, Article 106-2 of TFEU establishes that: "Undertakings entrusted with the operation of services of general economic interest ... shall be subject to the rules contained in this Treaty, in particular to the rules of competition, insofar as the application of such rules does not obstruct the performance, in law or in fact, of the particular tasks assigned to them".

${ }^{32}$ Article 2 of Regulation 1191/69 on transport by rail, road and inland waterways defines public service obligations as "obligations which the transport undertaking in question, if it were considering its own commercial interests, would not assume or would not assume to the same extent or under the same conditions".
} 
(Jaspers, 2009), integrating the general state aid regime, that gives room to state intervention for the purpose of correcting market imperfections such as absence of competition or externalities caused by congestion or environmental pollution. The limit to this opportunity is represented by the requirement that such a financing mechanism must not distort competition within the common market and must be compatible with State aid rules ${ }^{33}$ : compensation that exceeds what is necessary to discharge the public service mission could, as a matter of principle, result in illegality. For this purpose, regulation 1191/69, as amended by regulation 1893/91, established rules for calculating the compensations levels to apply in order to avoid the State aid notification and authorization procedures described in the EC Treaty.

As a whole, the regulatory framework on compensation remained for a long period barely applied, since public transport markets were mostly national or local, with a predominant share of transport services provided by public administration or local public monopolies, so that financial compensation or granting of exclusive rights could not be seen as seriously affecting trade among Member States (van de Velde, 2003; Goldberg, 2006). The successive, gradual, emergence of pan-European operators progressively changed the situation, arising again, and with more pressure, the central question regarding if financial compensations and exclusive rights can be considered compatible with the EC treaty. Accordingly, on the wake of important judgments of the European Court $^{34}$ and the demand for greater legal certainty and predictability expressed by the public consultation on the Green Paper on SGI (European Commission, 2003), the Commission launched a package ("Monti package") on Services of General Economic Interest and public service compensation ${ }^{35}$ which was adopted at the end of 2005. Through this measures, it is established that public service compensation is not considered state aid, and is also exempted by the notification requirement ${ }^{36}$, if it fulfils four conditions ${ }^{37}$ (European Commission, 2005 and 2010): the public service obligation should be clearly defined; the parameters of the compensation should be objective and established in advance in a transparent manner; the compensation cannot exceed the costs incurred in the discharge of public service obligations, taking into account the relevant

\footnotetext{
${ }^{33}$ It has to be remembered, that state aid rules are applicable if the conditions laid down in Article 107(1) of the TFEU are met: economic advantage, effect on trade between Member States and distortion of competition, selective nature of the measure.

${ }^{34}$ Judgment of the Court, C-280/00 Altmark Trans, and joined cases C-34/01 to 38/01 Enirisorse SpA.

${ }^{35}$ Commission Press Release - IP/05/937 - 15.7.2005, "State aid: Commission provides greater legal certainty for financing services of general interest".

${ }^{36}$ The decision has also exempted from notification PSO whose amount is under a certain threshold.

${ }^{37}$ The so called "Altmark conditions".
} 
receipts and a reasonable profit ${ }^{38}$; the company in charge of the mission should be either chosen through competitive procedures, or, if not, the costs of providing the public service must be based on the costs of a "typical, well run undertaking", including a reasonable profit.

Fourthly, the adoption of public service contracts is considered by regulation 1893/91 as the normal (but not mandatory) method to rule the relation between public authorities and undertakings entrusted with tasks serving the general economic interest. The regulation describes also the minimum contents of contracts, but none provision is established regarding the ways to award these contracts. Thus, while in other sectors (electricity, telecommunications, and postal services) European directives played a crucial role in boosting the liberalization process, the impact on inland transport remained feeble and centered on general principles. Member States continued to be free to decide how to organize transport services: either providing them directly or entrusting the provision to an external entity. If a public authority chooses to entrust the provision of LPT to a third party, the EU is neutral on the question of public or private ownership and does not consider tendering as compulsory, except in the cases where the public procurement rules apply (ie. in cases classified as public service contracts) ${ }^{39}$.

As a final remark, it's worth noting how the so called process of Europeanization has been characterized in LPT by an internal conflict: on the one hand, the need/will for boosting market competition and guaranteeing equal treatment to all potential providers - thus two objectives of the new European model triggered after the Single Act - and, on the other one, the safeguard of the principle of subsidiarity, which requires decision making and management options characterized by strong local commitments and freedom of choice. It is within this potential conflict that the more recent evolutions must be assessed.

\subsection{Regulation 1370/2007}

Regulation 1370/2007 (hereinafter R1370) on public passenger transport services by rail and by road (repealing regulation 1191/69) has been finally adopted in October 2007, after a long and tortuous way begun with the first proposal by the Commission in $2000 .^{40}$ The initial aims of the process were schematically twofold:

- to ensure legal certainty and fill in the voids of the existing regulatory framework. In particular, even if the European Court of Justice and National

\footnotetext{
${ }^{38}$ The term "reasonable profit" is defined as a rate of return on capital that is normal for the sector in a given Member State and that takes account of the risk, or absence of risk, incurred by the public service operator by virtue of public authority intervention.

${ }^{39}$ Directives 92/50, 93/36, 93/37, 93/38, and more recent directives 2004/18 and 2004/17.

${ }^{40} \mathrm{COM}(2000) 7$ final.
} 
initiatives had previously shaped the perimeter of application of the general EU principles in the case of service concessions and public service compensation, this not always happened in a unique and consistent manner and their precise relevance for LPT services remained ambiguous; ${ }^{41}$

- to ensure market access to all operators and stimulate a more competitive environment in the awarding of contracts. This aimed at giving execution to the provisions of the Lisbon Strategy and the EU White paper ${ }^{42}$ on market organization and awarding procedures in LPT services.

The final results of the bargaining process are summarised below.

\section{General purpose}

As stated above, the general purpose of R1370 (art.1) is to define how competent authorities may act in the field of passenger public transport respecting the rules of Community law (legal certainty). Hereto two important specifications are made.

Firstly, R1370 openly acknowledges the presence of general interests in transport services that can justify public intervention. In fact, according to (Whereas (5)): "many inland passenger transports cannot be operated on a commercial basis. Thus competent authorities of the Member States must be able to act to ensure that such services are provided. The mechanisms that they

\footnotetext{
${ }^{41}$ The concept is clearly stated by Whereas (6) of the new regulation: “...development in national legislations has led to disparities in the procedures applied and have created legal uncertainty as to the rights of public service operators and the duties of the competent authorities. Regulation (EEC) N. 1191/69 does not deal with the way public service contracts are to be awarded in the Community, and in particular the circumstances in which they should be the subject of competitive tendering. The Community legal framework ought therefore to be updated".

${ }^{42}$ The European Council of Lisbon of March 2000 required to speed up liberalisation in areas such as transport and supported the general principle of the development of competition for the provision of public transport services.

The White paper of 12 September 2001 "European transport policy for 2010: time to decide" summarised the main objectives of the EU Commission in the transport sector: "to guarantee safe, efficient and high quality passenger transport services through regulated competition, guaranteeing also transparency and performance of public passenger transport services, having regard to social, environmental and regional development factors, or to offer specific tariff conditions to certain categories of traveller, such as pensioners, and to eliminate the disparities between transport undertakings from different Member States". This includes three crucial elements:

- passenger transport services are considered services of general interest where the economic performance should be outweighed with social, environmental and regional development factors;

- regulated competition is envisaged as a key opportunity to meet all the (potentially conflicting) objectives of passenger transport services: efficiency, reliability, affordability, etc.

- distortions of competition should be avoided in awarding excusive rights to public service operators.
} 
can use to ensure that public passenger transport services are provided include the following: the award of exclusive rights to public service operators, the grant of financial compensation to public service operators and the definition of general rules for the operation of public transport which are applicable to all operators" and also (art. 1): "competent authorities may act in the field of public passenger transport to guarantee the provision of services of general interest which are among other things more numerous, safer, of a higher quality or provided at lower cost then those that market forces alone would have supplied". Secondly, within the framework of public intervention, it shows a preliminary favour towards transparent and non-discriminatory competitive procedures, recognising that (Whereas (7)) "the introduction of regulated competition leads to more attractive and innovative services at lower cost and is not likely to obstruct the performance of the specific tasks assigned to public service operators". In other words, regulated competition is seen as a promising tool to meet the general interest in an efficient way.

\section{Scope}

R1370 applies when exclusive rights and/or compensations are imposed to or contracted with service operators for the discharge of public service obligations (Art.1). This delineation undoubtedly concerns authority-initiated regimes, since they are run under a monopolistic market organization with an exclusive right, but also market initiative regimes where exclusive rights are awarded (for reason such as stability, integration, coordination, etc.). This means that market initiatives (both with open entry or regulated authorisation) without the awarding of exclusive rights and the concession of selective compensations, and for which only general rules ${ }^{43}$ apply (minimum licensing standards, special tariffs, etc.), are not affected by the regulation and are still a viable option (van de Velde, 2003). ${ }^{44}$ Of course, there remains the preliminary support for regulated competition, so that deregulation can be seen as an accepted but not favoured alternative.

A second demarcation of the scope of application of R1370 regards modes. Only inland public passenger transports are included ${ }^{45}$, with the exception of those operated mainly for their historical interest or their tourist value. Within this

\footnotetext{
${ }^{43}$ According to the definitions included in the Art.2 of the Regulation, 'general rule' means a measure which applies without discrimination to all public passenger transport services of the same type in a given geographical area for which a competent authority is responsible.

${ }^{44}$ According to Whereas (8): "Passenger transport markets which are deregulated and in which there are no exclusive rights should be allowed to maintain their characteristics and way of functioning in so far as these are compatible with Treaty requirements". This definition clearly states that from a legal point of view the decisive boundary between regulated/deregulated markets is represented by the presence of exclusive rights.

${ }^{45}$ States are also free to apply this Regulation to public passenger transport by inland waterways and to maritime transport within Member States (maritime cabotage) national sea waters.
} 
general statement, the application to buses, trams, metros and rail modes is subject to some, at times relevant, differences (application of directives on public service contracts, awarding mechanisms, etc.).

Thirdly, R1370 applies, for buses and trams, only when contracts take the form of service concession contracts, while in other cases (public service contracts) public procurement directives (2004/17/EC and 2004/18/EC) are relevant. For rail and track-based modes other than tram, R1370 always applies (van de Velde et al., 2008). The application of R1370 rather than public procurement directives turns out to be quite significant (ibidem): on the one hand, the latter are already fully binding while R1370 provides for a long transitional period, and, on the other, they establish more detailed and restrictive procedures, above all as regards the application of competitive tendering procedures (see box 3 and below). According to this view, it seems that where contractors are, to a certain degree, disciplined by market incentives (mainly through risk sharing on revenues) less strict (and even complex) tendering rules can be acceptable.

Box 3. Public service contracts and public service concession in local public transport: a case study

The European Commission decided to send a formal request to the Czech Republic concerning the procedure followed by the Czech Region of Ustinad Labem for the award of a contract to a private undertaking for the provision of regional bus transport services. This formal request takes the form of a "reasoned opinion", the second stage of the infringement procedure laid down in Article 226 of the EC Treaty. If there is no satisfactory reply within two months, the Commission may refer the matter to the European Court of Justice.

The Commission considers that the contract concluded between the Region and the private operator is a public service contract and that as such it should have been tendered according the detailed rules of Directive 2004/17/EC.

However, the Region awarded the provision of the transport services in the Region as a service concession and thus without a European-wide tender procedure.

In case of a service concession, the concessionaire receives the right to exploit the service and must assume the economic risk related to the performance of the service ${ }^{46}$. In the present case the major part of the operator's remuneration comes from the Region, because the income from passenger fares would not be sufficient for the provision of the service. This payment by the Region eliminates the exploitation risk. Consequently, the contract award does not concern a concession but a public contract, which requires the observation of the detailed rules of Directive 2004/17/EC.

Source: European Commission, IP/08/1030, Brussels, 26 June 2008.

\section{Role of contracts}

R1370 generalises the use of public service contracts to rule the relationship between the competent authority and a public service operator, establishing binding contents ${ }^{47}$ and duration ${ }^{48}$. Contracts represent the key and mandatory

\footnotetext{
${ }^{46}$ The same concept is expressed in European Commission (2010 p. 75-76): "The existence of a risk is therefore essential in order to determine whether a service is a concession... concession exists only if a significant part of the risk is transferred to the operator....The risk to be taken into account are those involved in providing the service or making available or use the work, particularly the risk associated with demand".

${ }^{47}$ According to Article 4, public service contracts (and even general rules) must: define the public service obligations and the geographical areas concerned; establish, in an objective and transparent manner, the parameters on the basis of which the compensation payment, if any, is to be calculated, and the nature and extent of any exclusive rights granted in order to avoid
} 
instrument of regulation and liberalization, since they give shape to the extent and the main characteristics of public intervention: exclusive rights, public service obligations, compensation, risk sharing, quality standards, etc.

The definition of contracts adopted by the EU is actually very wide. Public service contract is in fact defined (art 2(i)) as a "legally binding act confirming an agreement between a competent authority and a public service operator": a definition clearly referring to a civil law instrument, where a bilateral document is voluntarily signed by both the parties with the aim of ruling their relationship; but may also consist, depending on the law of the Member States, "of a decision adopted by the competent authority:

- taking the form of an individual legislative or regulatory act, or

- containing conditions under which the competent authority itself provides the services or entrusts the provision of such services to an internal operator".

Thus, any unilateral public law instrument (laws, regulations, administrative acts, etc.) is included in the definition and is as well disciplined by the regulation.

Of course the role of the two alternatives is very different ${ }^{49}$.

In the first case, the contract is typically a market mechanism, through which the competent authority buys a service from an external operator. It has to describe the separation of roles and define responsibility and risk allocation between the competent authority and the operator; furthermore it has a legal force and can be exploited to govern subsequent modifications or disputes.

In the second case, it is mainly an internal and authoritative act, in a context where the separation of roles is weak and no true market transactions and risk sharing are developed. This second type applies in the case of self-production (see case A in Fig. 2), and in that of self owned companies (case B.1 in Fig. 2) when the requisites of the "internal operator" (see below) are verified.

According to this view, only the first type of contract can be consistent with some form of liberalization as defined in $\S 2.3$.

overcompensation; determine the arrangements for the allocation of costs connected with the provision of services; determine the arrangements for the allocation of tickets (risk sharing); determine service quality standards; indicate whether, and if so to what extent, subcontracting may be considered; define in a transparent way the contractual conditions and the specific social standards eventually applied to existing labour staff.

${ }^{48}$ The duration of contracts is limited to 10 years for coach and bus services, 15 years for rail based services and 15 years for multimodal contracts if rail services account for more than half of the value of the contract. The duration can be extended by $50 \%$ if the operator provides significant assets in relation with the service provision described in the contract.

${ }^{49}$ The difference between the two is confirmed by art 1: "To this end this Regulation lays down the conditions under which competent authorities, when imposing or contracting for public service obligation...." where it is clearly stated that the contractual logic (as a bilateral act) is different from that (unilateral) of imposing a public service obligation. 


\section{Organizational forms}

R1370 allows freedom of choice for local authorities among three organizational forms:

1) self production by means of an internal department, with no other specific clause attached;

2) direct award to an internal operator, i.e. a legally distinct entity over which the competent local authority exercises control similar to that exercised over its own departments. This is the so called "in house" option $^{50}$, where the definition of the internal operator is subject to several restrictive conditions, partly already ruled by the EU Court of Justice ${ }^{51}$. Yet, differently by the previous statements of the European jurisprudence, the $100 \%$ ownership is not included as a mandatory requirement so that a private share is not deemed as incompatible with a direct award if the "dominant public control" can be established on the basis of other criteria.

3) award to a third party other than an internal operator through tendering procedures. In this case the procedure may involve preselection and, afterwards, negotiations, leaving a certain room of manoeuvring to the

\footnotetext{
${ }^{50}$ The true nature of the in house solution is well described by the recent Guide of the European Commission (European Commission, 2010, p. 59): "The in house exception is meant to cover a situation where public authority decides to provide a service itself, albeit acting through a legally distinct entity. In this case the public authority and the entity providing the service are effectively regarded as one. Such a relationship is covered neither by the principles of transparency, equal treatment and non-discrimination derived from the Treaty, nor by the Public Procurement Directive".

${ }^{51}$ Case 107/98 "Teckal", Case 26/03 "Stadt Halle", Case-458/03 "Parking Brixen GmbH". Taking this jurisprudence and article 2 of R1370 into account, an "internal operator" should meet the following criteria (Jaspers, 2009; European Commission, 2010):

- be a legally distinct entity;

- control has to be exercised over it by a competent local authority (i.e. a single local government), or in the case of a group of authorities (syndicate, agency, associations, etc.) at least one competent local authority, to an extent similar to the control this authority exercises over its own departments. This means that the public authority must, in any case, exercise a degree of control over the entity that allows it to have a decisive influence on both the strategic objectives and the major decisions of the entity;

- the internal operator and any entity over which this operator exerts even a minimal influence should perform the essential part of their public transport passenger activity within the territory of the competent local authority or authorities;

- the internal operator and any entity over which this operator exerts even a minimal influence should not take part in competitive tenders concerning the provision of public passenger transport services organised outside the territory of the competent local authority; this limitation can be avoided only when it is established that the home market of the internal operator is going to be opened up to competition. In this case, in fact, the internal operator directly entrusted of service provision may take part in competitive tenders outside its territory 2 years before the end of its awarded contract;

- the internal operator should perform the major part of the public passenger transport service itself and not by subcontracting.
} 
competent authority in order to define and describe the complex market system he wants to obtain. Accordingly, through the application of $\mathrm{R} 1370$, the competent authority is subject to less explicit and detailed provisions in running its awarding procedure ${ }^{52}$ then it would have been under the regime of the public procurement directives, which explicitly regulates issues such as timelines, the amount of information to be given about the contract to be awarded, number and weights of awarding criteria, etc. (van de Velde et al, 2008; European Commission, 2010).

The recourse to an external operator can be possible even through a direct award (i.e. without a public tender) in selected specific cases:

- contracts concerning transport by rail, with the exceptions of other track-based modes such as metro or tramways;

- contracts beneath certain thresholds (de minimis $)^{53}$;

- in the case of urgency, for up to two years.

The flexible approach adopted by the EU is confirmed by the timetable: R1370, in fact, came into force in December 2009 and with a 10-years transitional period. This means, in particular, that the award of public service contracts shall fully comply with the above mentioned conditions from 3 December 2019. Furthermore, existing contracts can still be valid under certain circumstances (Table 1).

Table 1. Transitional period

\begin{tabular}{|l|c|c|}
\hline & Contracts awarded before July 2000 & $\begin{array}{c}\text { Contracts awarded after July 2000 and } \\
\text { before entry into force of R1370 }\end{array}$ \\
\hline & May continue until their expire & $\begin{array}{c}\text { May continue until they expire if duration is } \\
\text { less than } 30 \text { years }\end{array}$ \\
\hline \\
\hline
\end{tabular}

Source: adaptations on Goldberg (2006).

However, during the second part of the transitional period (i.e. starting by 2015), the awarding competent authorities (national or local) may exclude from

\footnotetext{
${ }^{52}$ The procedure shall be open to all operators, shall be fair and shall observe the principles of transparency and non-discrimination (article 5.3 of R1370).

${ }^{53}$ Contracts whose value is less than 1 Million $€$ or concerning less than $300.000 \mathrm{~km}$ of service. Both thresholds are doubled in the case of a public service contract directly awarded to a small or medium-sized enterprise (i.e. an enterprise operating less than 23 vehicles).
} 
participation in competitive bids operators whose less than half of the value of their contracts (for which they are receiving a public compensation or enjoy an exclusive right) are granted in accordance with the regulation. Such exclusion shall not apply to public transport operators running the services which are to be tendered. This reciprocity rule essentially aims at preventing that large authority-owned monopolies could unfairly compete outside their territorial bounds using their preferential position and/or part of the subsidy obtained at home.

As a whole, the limitations established by R1370 on organizational models, awarding mechanisms, scheduling, etc. are to be intended as "minimum standards". In fact, the freedom of choice concerning organizational models applies only to the relationship between the EU and Member States, but the latter are allowed to be more "pro-competitive" and to restrict the margin of manoeuvring of local authorities. Basically, national, and even sub-national regulations can be more restrictive (and therefore more pro-competitive) but not more permissive. For example: national laws can prohibit (or restrict) options 1) and 2), i.e. self production and in house award; they can limit spaces for direct award (rail services, de minimis); they can prohibit the so called internal operator from taking part in competitive tenders even within its own territory; they can shorten the transitional period, etc. As a matter of fact, the concrete impact of the normative framework is to a large extent left to national measures.

\section{Compensation}

In order to avoid compensation, R1370 establishes detailed rules for the proper calculation of compensation related to public service obligations. Rules are laid down in the annex and reflect the contents of the so called Altmark criteria (see above). In particular, compensation may not exceed an amount corresponding to the net financial effect of the total effects, positive or negative, of compliance with the public service obligation on the costs and revenue of the public service operator, including a reasonable profit.

The correct evaluation of many of the elements of the proper calculation of the compensation - costs incurred in relation to a public service obligation, financial benefits, tariffs and commercial revenues, reasonable profit - is not an easy task and can cause additional administrative duties and controversies ${ }^{54}$. But, if the provider is selected by way of a tender based on objective and transparent criteria, the fee is deemed to comply with all the criteria set in the judgement of the European Court of Justice in the Altmark case: so it does not constitute state aid and does not require being motivated to the European Commission (Jaspers, 2009; European Commission, 2010). For that reason, public tendering to a third

\footnotetext{
${ }^{54}$ Competent authorities, in fact, must be able to proof within short periods to the Commission that their payment structure is in accordance with the rules laid down in the annex.
} 
party can be seen as the easiest solution for meeting the Altmark criteria and respecting state aid discipline.

\section{Conclusions}

The adoption of the EU regulation on inland transport represented the object of a protracted conflict between the will to foster competitiveness and guarantee equal treatment to all potential providers and that of safeguarding the principles of subsidiarity and local democracy. In particular, while competitive tendering and regulated competition denoted the starting and general principle of the EU Commission proposal, still evoked in the Whereas (6) of the adopted R1370, some Member States and the EU Parliament called upon the subsidiarity rule to prevent the full acceptance of this point. The outcome has been a framework strictly linked to the principles included in the French legislation, according to which local authorities can produce services themselves or decide to contract these out by the way of tendering.

This flexible approach turns out to be a reasonable compromise, even because lower levels of governments are free to establish a more competitive environment. What is actually required to transport authorities, and has to be evaluated as a positive outcome, is to make an unambiguous choice between internal regulation and outsourcing.

Through internal regulation, competent authorities should aim to keep (for technological reasons, for informational shortages, due to high transaction costs, etc.) all the decisional levers within the framework of the administrative activity, without delegating to external suppliers. This choice is therefore consistent only with self-production or with the involvement of a legally distinct entity strictly controlled by the local authority and linked to the territory where it operates, i.e. the internal (in house) option delineated by the EU ruling. Accordingly, two other relevant features complete this context (Fig. 6):

- contracts cannot be intended as true agreements between two parts, but as unilateral/imposed acts of entrustment;

- competitive procedures are not required, because none third party is involved and no discrimination risk concretely emerges; but even because all principal-agent relationships are demanded to the hierarchical control and not to "market discipline".

On the other hand, through outsourcing, the authority wants to exploit, at a certain level of the decisional chain, the involvement of external providers (both public or private) in terms of skills, specialization, flexibility, risk assumption, etc. To play this role, operators need to be (at least partially) separated from the organizing authority and to have margin of maneuvering and freedom in relation to the main management levers (innovation, tactical or operative decisions, budget, enrolments criteria, etc.). In this case, since a direct and strict administrative control is not exploitable, legally enforceable contractual agreements, and even open awarding procedures, can be seen as important tools 
to discipline the performance of the operator, and, at the same time, to guarantee the respect of the non-discrimination rule.

Figure 6. Awards of public service contracts according to R1370

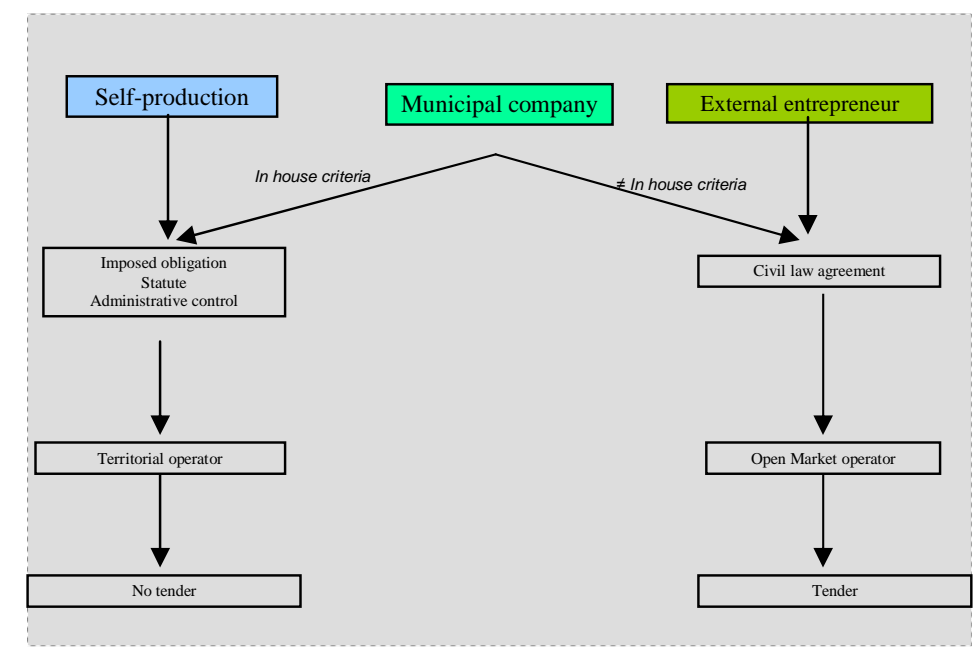

The way and the opportunity to make recourse to self-owned company/municipal company (B.1 in Figure 2 above) are strongly influenced by this framework, as a precise choice between the internal operator-model or a more market-oriented and entrepreneurial player has to be carried out. In fact, it is not deemed possible (neither logical) to award the service to an external operator (even though totally or largely owned and controlled by the same competent authority responsible for the service) that holds legal, budgetary, decisional and managerial autonomy, without submitting it to market discipline through competitive procedures and true contractual arrangements.

\section{Power of initiative and multilevel governance in European urban transport}

The main aim in this section is to describe, on the one hand, if national models give evidence for a progressive dismantling of the strategic role of public authorities and, on the other, which kind of multilevel structure public intervention acquires within different experiences.

The horizontal analysis carried out on the selected EU countries (Table 2) identifies three main features: persisting public regulation, decentralization and new governance structures. 
Table 2. Public regulation and multilevel governance in the selected EU countries

\begin{tabular}{|c|c|}
\hline \multicolumn{2}{|r|}{ Austria } \\
\hline $\begin{array}{l}\text { Multilevel } \\
\text { structure }\end{array}$ & 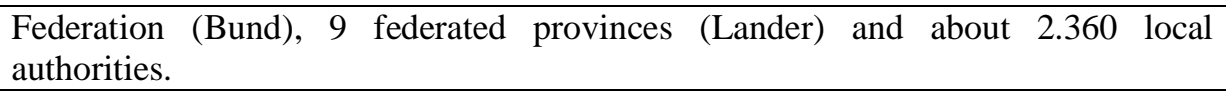 \\
\hline $\begin{array}{l}\text { Multilevel } \\
\text { governance of } \\
\text { LPTs }\end{array}$ & $\begin{array}{l}\text { All legislative and executive powers related to rail transport are assigned to the } \\
\text { Federal State (including all rail-bound services). } \\
\text { Lander and municipalities have the responsibility for the provision of local and } \\
\text { regional road passenger transport. No legal distribution of responsibilities between } \\
\text { the Lander and Municipalities exists. }\end{array}$ \\
\hline $\begin{array}{l}\text { Power of } \\
\text { initiative and } \\
\text { competent } \\
\text { authorities }\end{array}$ & $\begin{array}{l}\text { Market initiative regime with exclusive authorization for economically profitable } \\
\text { routes. } \\
\text { Non profitable routes have to be tendered under the authority initiative. } \\
\text { Strong defensive approach with respect to the established incumbent operators: - } \\
\text { the transport route applied for by the market entrepreneur must not run counter the } \\
\text { public interest (i.e. the interest of the incumbent); almost all payments granted by } \\
\text { the government to historical providers are considered as "fare revenues" so that } \\
\text { their routes are considered profitable. As a matter of fact, only additional services } \\
\text { and/or extension of existing ones are tendered. } \\
\text { Competent authorities are commonly municipalities. } \\
\text { Increasing role of Transport Associations as intermediate regulatory and advisory } \\
\text { authorities. Transport Associations are forms of intermunicipal cooperative bodies } \\
\text { among local authorities and operators to optimize LPT services. They mainly } \\
\text { operate to gather resources from different public actors, to distribute fare revenues } \\
\text { among operators, to define a standardized fare system and an integrated timetable, } \\
\text { to manage tendering procedures on behalf of local governments, to manage quality } \\
\text { standard and monitoring, to suggest public transport planning to the local } \\
\text { authorities. } \\
\text { Austria is now split into eight Transport Associations that cover the whole country. } \\
6 \text { provinces have their own transport associations, while the remaining three are } \\
\text { divided into two transport associations. Each transport association commonly } \\
\text { groups local governments, the provincial government as well as bus operators. } \\
\text { In Innsbruck, IVB (a limited liability company) plans the network and the services } \\
\text { to be offered; it also directly provides tram and metro services. IVB plays all the } \\
\text { tactical decision and even some strategic ones. }\end{array}$ \\
\hline \multicolumn{2}{|r|}{ Belgium } \\
\hline $\begin{array}{l}\text { Multilevel } \\
\text { structure }\end{array}$ & $\begin{array}{l}\text { Federal government, } 3 \text { regions (Wallon, Flemish and Brussels), } 10 \text { provinces and } \\
\text { around } 590 \text { municipalities. }\end{array}$ \\
\hline $\begin{array}{l}\text { Multilevel } \\
\text { governance of } \\
\text { LPTs }\end{array}$ & $\begin{array}{l}\text { Since } 1988 \text { regional and local transports are delegated to regional governments } \\
\text { fully responsible to organize public transport in their area. }\end{array}$ \\
\hline $\begin{array}{l}\text { Power of } \\
\text { initiative and } \\
\text { competent } \\
\text { authorities }\end{array}$ & $\begin{array}{l}\text { Authority initiated regime. } \\
\text { The competent authority is the regional government. None sectoral functional } \\
\text { agency has been created. } \\
\text { Public companies owned by regional governments provide services but have also } \\
\text { responsibilities to define tactical and (at least some) strategic decisions. In } \\
\text { Wallonia and Flanders they are also acquiring a regulatory role since they sub- } \\
\text { contract an increasing part of their network to private operators. }\end{array}$ \\
\hline \multicolumn{2}{|r|}{ France } \\
\hline $\begin{array}{l}\text { Multilevel } \\
\text { structure }\end{array}$ & $\begin{array}{l}\text { Central government, } 26 \text { regions, } 100 \text { departments (counties) and around } 36.683 \\
\text { municipalities }\end{array}$ \\
\hline $\begin{array}{l}\text { Multilevel } \\
\text { governance of } \\
\text { LPTs }\end{array}$ & Since 1982, decentralization to counties and municipalities. \\
\hline
\end{tabular}




\begin{tabular}{|c|c|}
\hline $\begin{array}{l}\text { Power of } \\
\text { initiative and } \\
\text { competent } \\
\text { authorities }\end{array}$ & $\begin{array}{l}\text { Public authority initiative: transport authorities have the legal monopoly of } \\
\text { initiative. } \\
\text { Local authorities have the authority to define the characteristics of the service and } \\
\text { the mode of organization of their urban public transport system. } \\
\text { Strong development of inter-municipality and cooperation to compensate for the } \\
\text { small size of French municipalities. } \\
\text { In several cases the competent authority is an association (agglomeration) of cities } \\
\text { under different legal forms. Only about } 20 \% \text { of urban organizing authorities are } \\
\text { communes working alone. } \\
\text { In Paris the regulatory role is played by the STIF, a transport syndicate joined by } \\
\text { the region, the city of Paris and other } 7 \text { counties of the region. Within the process } \\
\text { of decentralization the national Government abandoned its role within the steering } \\
\text { committee in } 2005 \text {, leaving the leading role to the regional government. The } \\
\text { syndicate is responsible for: contract design and endorsing, tariff setting, } \\
\text { investment planning, quality management. } \\
\text { In Rouen the competent agglomeration includes } 71 \text { municipalities and nearly } \\
500.000 \text { inhabitants; the agglomeration is in charge of other relevant tasks: } \\
\text { organization of public services (water, sanitation, waste), the development of the } \\
\text { attractiveness of the territory, the spatial and political solidarity. } \\
\text { In Lyon the organizing authority is a syndicate grouping } 64 \text { municipalities. The } \\
\text { syndicate is responsible for the transport policy, the management and development } \\
\text { of the transport network and the delegation of its management to an operator. }\end{array}$ \\
\hline \multicolumn{2}{|r|}{ Germany } \\
\hline $\begin{array}{l}\text { Multilevel } \\
\text { structure }\end{array}$ & $\begin{array}{l}\text { Federation (Bund), states (Lander), districts and municipalities (around 12.300). } \\
\text { Largest municipalities are also city districts. Berlin, Bremen and Hamburg also } \\
\text { have the status of Lander. }\end{array}$ \\
\hline $\begin{array}{l}\text { Multilevel } \\
\text { governance of } \\
\text { LPTs }\end{array}$ & $\begin{array}{l}\text { After the German reunification, the decentralization of planning and financial } \\
\text { responsibilities (since 1993) has been one of the main changes. } \\
\text { Lander or regional transport associations are responsible for regional railways } \\
\text { services, while other modes are delegated to districts and city districts. Cities- } \\
\text { Lander are responsible for the all modes. }\end{array}$ \\
\hline $\begin{array}{l}\text { Power of } \\
\text { initiative and } \\
\text { competent } \\
\text { authorities }\end{array}$ & $\begin{array}{l}\text { Market initiative regime with regulatory checks at the entrance for profitable routes } \\
\text { through a system of exclusive authorizations (normally for } 8 \text { years). Competent } \\
\text { authorities are granted the power to define passenger transport plans that can be } \\
\text { decisive when operators request authorizations to provide transport services. } \\
\text { Non-profitable routes purchased by the competent authorities have to be tendered. } \\
\text { The legal distinction between profitable and non-profitable services is not always } \\
\text { effective and various kinds of subsidies (as those on rolling stock investments) and } \\
\text { cross-subsidies (such as those coming from energy) blur the distinction itself. } \\
\text { Financial support to locally owned public company is organized in such a way and } \\
\text { markets are so strictly regulated that freedom of initiative hardly exists and } \\
\text { incumbents have, de facto, a preferential position. } \\
\text { Landers are the competent autorities for regional railways, while districts and city } \\
\text { districts for other modes. } \\
\text { Local competent authorities are normally members, together with transport } \\
\text { operators, of transport associations (Verkehrsverbunde), coordinating public } \\
\text { transport services on a larger scale. By 1990, virtually every metropolitan area in } \\
\text { Germany has such transit organization. Transport associations can have different } \\
\text { roles. They integrate services of different operators and different competent } \\
\text { authorities into a coordinated public transport system; they provide an integrated } \\
\text { fare scheme; they share revenues among operators; they coordinate timetables, } \\
\text { sales and communications. In some cases, they can even determine the service } \\
\text { level and quality. } \\
\text { In the Berlin and Brandenburg Lander the Verkehrsverbund Berlin-Brandebourg }\end{array}$ \\
\hline
\end{tabular}




\begin{tabular}{|c|c|}
\hline & $\begin{array}{l}\text { (VBB) is established. It is a limited liability company shared by the } 2 \text { Landers, } 14 \\
\text { disctricts and } 4 \text { city districts. The VBB plans and coordinates regional railway } \\
\text { services of both the Landers. For other modes it manages tariff integration and } \\
\text { revenue sharing on the whole area; it is responsible for marketing and users' } \\
\text { information; it is responsible for quality and contracts monitoring. } \\
\text { In the Hamburg, Lower Saxony and Schleswig-Holstein Lander, the Hamburger } \\
\text { Verkehrsvernbund (HVV) is established. It is a private-law company (limited } \\
\text { liability company) shared by } 3 \text { Lander, } 7 \text { districts and more than } 30 \text { transport } \\
\text { operators, that coordinates the integrated transport system in the area. HVV sets } \\
\text { fares, coordinates routes and timetables; it establishes minimum requirements for } \\
\text { service supply, bus stops and passenger information. } \\
\text { In the city of Frankfurt the regulatory authority is played by traffiQ, a limited } \\
\text { liability company owned by the city of Frankfurt. TraffiQ determines the service } \\
\text { design (routes, timetables, fares), provide information, manages tendering } \\
\text { procedures, and carries on users surveys. } \\
\text { In Munich, the Munchner Verkehrs und Tarifverbund (MVV) has been established } \\
\text { as a limited liability company to play the regulatory role in the metropolitan area. } \\
\text { The Lander capital Munich, Free State of Bavaria, eight administrative districts and } \\
50 \text { transport companies work together in this transport association as partners. } \\
\text { Main tasks of MVV include: joint tariff management, distributing revenues, } \\
\text { planning and contract management of regional bus services, conceptual transport } \\
\text { research, system marketing, providing comprehensive customer information as } \\
\text { well as carrying out transport research and market research. }\end{array}$ \\
\hline \multicolumn{2}{|r|}{ Italy } \\
\hline & Central government, 20 regions, 110 provinces and nearly 8.100 municipalities \\
\hline $\begin{array}{l}\text { Multilevel } \\
\text { governance of } \\
\text { LPTs }\end{array}$ & $\begin{array}{l}\text { Since 1997: regionalization of legislative, planning and financial responsibilities. } \\
\text { Further delegation of operational functions to local administrations except for those } \\
\text { services requiring a unitary management at the regional level. } \\
\text { Regional governments have the direct responsibility to plan, organize and regulate } \\
\text { railways services of "regional and local interest". They also have the responsibility } \\
\text { to establish the relevant basin for other modes and to define and finance "minimum } \\
\text { services" which should be quantified accordingly to the mobility needs and } \\
\text { characteristics of the corresponding transport basin. } \\
\text { Local governments (provinces or large municipalities) are responsible to plan, } \\
\text { design and manage modes different from rail. They also have the responsibility to } \\
\text { establish and finance additional services (other than minimum services covered by } \\
\text { the regional level) corresponding to specific needs and users preferences. }\end{array}$ \\
\hline $\begin{array}{l}\text { Power of } \\
\text { initiative and } \\
\text { competent } \\
\text { authorities }\end{array}$ & $\begin{array}{l}\text { Public authority initiative with the opportunity (since 2006) to grant licenses to } \\
\text { market operators that develop services on their own initiative, on condition that } \\
\text { they possess fitting technical and professional requirements and that none financial } \\
\text { compensation is required. } \\
\text { Competent authorities are Regions for regional railways and districts and } \\
\text { municipalities for other modes. } \\
\text { Scattered development of cooperation through the development of supra-municipal } \\
\text { bodies. In several cases territorial integration is partly granted by the central city } \\
\text { that extends its own services towards the neighboring municipalities. } \\
\text { Independent regulatory authorities (agencies) have been created in several cases, } \\
\text { even if with varying degrees of autonomy and power. In some cases (eg. Milan), } \\
\text { the role of the agency is limited to technical assistance to political bodies involved } \\
\text { in planning and operative activities. In other cases (e.g. Roma and Bologna, where } \\
\text { agencies assume the legal form of a stock-option company) they are responsible for } \\
\text { key regulatory tasks: definition of service contracts, awarding of tenders, asset } \\
\text { ownership and management, network planning, revenue management, monitoring }\end{array}$ \\
\hline
\end{tabular}




\begin{tabular}{|c|c|}
\hline & $\begin{array}{l}\text { and performance control, information. In Turin the agency is an interinstitutional } \\
\text { syndicate among the Region Piemonte, the Province, the Municipality of Turin and } \\
31 \text { surrounding small municipalities; the agency plays important regulatory tasks: } \\
\text { planning of services and infrastructures, quality monitoring and management, fares } \\
\text { and subsidies management, contract management. }\end{array}$ \\
\hline \multicolumn{2}{|r|}{ Poland } \\
\hline $\begin{array}{l}\text { Multilevel } \\
\text { structure }\end{array}$ & Central government, 16 regions, 314 counties and nearly 2.500 municipalities \\
\hline $\begin{array}{l}\text { Multilevel } \\
\text { governance of } \\
\text { LPTs }\end{array}$ & $\begin{array}{l}\text { Up to } 1990 \text {, local and regional transportations were provided by state enterprises: } \\
\text { national railways and one state-owned bus company. } \\
\text { After 1990, local public transports are under the full responsibility of local } \\
\text { governments. Autonomy and responsibility of local self-government have been } \\
\text { further strengthened by the Constitutional reform of } 1997 \text {. }\end{array}$ \\
\hline $\begin{array}{l}\text { Power of } \\
\text { initiative and } \\
\text { competent } \\
\text { authorities }\end{array}$ & $\begin{array}{l}\text { Both public and private initiative. Profitable services can be licensed (without } \\
\text { exclusivity) following an application by market operators including professional } \\
\text { qualifications, timetables, routes and tariffs. The license can be refused if } \\
\text { represents a threat to the already existing lines. } \\
\text { Competent authorities are municipalities that can freely decide on the } \\
\text { organizational form to provide services (self-production, municipal companies, } \\
\text { civil law contracts, etc.) } \\
\text { Public transport authorities have been created in several cases (Gdansk, Cracow, } \\
\text { Poznam, for example) to play the regulatory role: managing the network, tendering } \\
\text { lines, monitoring quality, fares management, marketing. Public transport } \\
\text { authorities are generally public sector entity without legal personality, covering } \\
\text { their costs directly from the budget. } \\
\text { Inter-communal associations can be developed to carry out public services. } \\
\text { In Warsaw a Municipal Transport Management Authority (ZTM) is established to } \\
\text { organize transport for the city. ZTM acts according to the Statute set by the } \\
\text { Warsaw city Council and according to the law on transport services. ZTM buys } \\
\text { services from several operators and then manages contracts and controls quality. } \\
\text { In Cracow the City created a public transport authority, as an internal department, } \\
\text { to regulate public service contracts. } \\
\text { In Elblag the Public transport authority is a limited liability company that organizes } \\
\text { tenders and manages contracts with operators. }\end{array}$ \\
\hline \multicolumn{2}{|r|}{ Spain } \\
\hline $\begin{array}{l}\text { Multilevel } \\
\text { structure }\end{array}$ & $\begin{array}{l}\text { Central government, } 17 \text { autonomous communities (regions), } 50 \text { provinces and } \\
\text { nearly } 8.110 \text { municipalities }\end{array}$ \\
\hline $\begin{array}{l}\text { Multilevel } \\
\text { governance of } \\
\text { LPTs }\end{array}$ & $\begin{array}{l}\text { The national government keeps responsibility on railways. } \\
\text { Competences on local and regional public transport are decentralized to local } \\
\text { governments as in the case with other policies related to mobility, e.g. urban and } \\
\text { spatial planning, environment. }\end{array}$ \\
\hline $\begin{array}{l}\text { Power of } \\
\text { initiative and } \\
\text { competent } \\
\text { authorities }\end{array}$ & $\begin{array}{l}\text { Public authority initiative by own production or delegation to private operators. } \\
\text { Competent authorities for modes other than railways are local governments, often } \\
\text { through intermunicipal syndicates; the latter are cooperative arrangements taking } \\
\text { the form, on the basis of inter-institutional dialogue, of transport independent } \\
\text { agencies in the main urban agglomerations of the country. In several cases } \\
\text { representatives of the upper level of government (State, Autonomous Regions, } \\
\text { Provinces) take part in the syndicate. The number of intermunicipal transport } \\
\text { authorities increased from } 4 \text { in } 1997 \text { to } 18 \text { in } 2007 \text {. } \\
\text { In Madrid a Transport Syndicate (CRTM) was established in } 1986 \text { for the purpose } \\
\text { of coordinating services, networks, and fares on the whole region of Madrid. The } \\
\text { National government, the Autonomous Community of Madrid and the Municipal } \\
\text { governments take part to the syndicate; even trade unions, operators and } \\
\text { consumers' associations are represented. CRTM is the competent authority in all }\end{array}$ \\
\hline
\end{tabular}




\begin{tabular}{|c|c|}
\hline & $\begin{array}{l}\text { aspects related to: contracting, regulation, planning and operation, information, } \\
\text { tariff setting and integration, monitoring of results. Municipalities joining the } \\
\text { CRTM delegate the responsibility to plan and manage transport services to the } \\
\text { cooperative authority; on its own, CRMT plans services and their characteristics in } \\
\text { accordance with the participating municipalities. Municipalities within the region } \\
\text { are not obliged to join CRTM, but almost all of them take part to it: this is because } \\
\text { they recognize the benefits that some integration of transport across the region } \\
\text { brings to their citizens. According to ECMT (2002 p.5): "The creation of a single } \\
\text { body for public transport has enormously improved the situation that previously } \\
\text { prevailed in the Spanish capital region". } \\
\text { In Barcelona, the Metropolitan Transport Authority (EMT-Entitat Metropolitana de } \\
\text { Transports) is a public authority on which } 18 \text { local authorities, including } \\
\text { Barcelona, are represented according to their population. EMT is part of a larger } \\
\text { Metropolitan Transport Authority (ATM) that has been established in } 1997 \text { under } \\
\text { the form of a voluntary inter-administrative consortium formed by the Autonomous } \\
\text { Government of Catalonia, the city of Barcelona, and the EMT itself; the national } \\
\text { state has an observer role. The role of ATM is composite: planning of long- } \\
\text { distance interurban bus services, coordination between public administrations in } \\
\text { charge of providing LPT in the different sub-regions, coordination among modes, } \\
\text { follow up of contracts, tariff setting and integration, revenue collection and sharing } \\
\text { among operators, communication and marketing. The relationship between and } \\
\text { respective roles of EMT and ATM continue to be defined and reshaped. }\end{array}$ \\
\hline \multicolumn{2}{|r|}{ Sweden } \\
\hline $\begin{array}{l}\text { Multilevel } \\
\text { structure }\end{array}$ & Central government, 21 counties and 290 municipalities. \\
\hline $\begin{array}{l}\text { Multilevel } \\
\text { governance of } \\
\text { LPTs }\end{array}$ & $\begin{array}{l}\text { The national government keeps responsibility on railways. } \\
\text { The principle of local self-government is one of the fundamental principles of the } \\
\text { Swedish democratic system. Since } 1978 \text { Counties and municipalities are } \\
\text { responsible for local and regional public road transportation. }\end{array}$ \\
\hline $\begin{array}{l}\text { Power of } \\
\text { initiative and } \\
\text { competent } \\
\text { authorities }\end{array}$ & $\begin{array}{l}\text { Public authority initiative by local governments. } \\
\text { In the early } 80 \text { s separated public transport authorities (PTAs) have been created in } \\
\text { several territories to play the regulatory role: planning and coordination of bus } \\
\text { networks, setting and integrating tariffs, managing tendering procedures, } \\
\text { negotiating the economic compensation with operators. Transport authorities } \\
\text { usually cover the Swedish counties and often acquire the form of private law } \\
\text { company owned by the corresponding local administration. Voluntary regional } \\
\text { public transport bodies can be developed to integrate fares and services within the } \\
\text { whole region and even to procure internal bus services for counties who wish this } \\
\text { to be done on their behalf, on an agency basis. } \\
\text { In Stockholm the regulatory role is played by a transport authority (SL) responsible } \\
\text { for all public transport services in the area. SL is totally owned by the Stockholm } \\
\text { County Council. } \\
\text { In Sundsvall the regulatory role is played by a transport authority responsible for } \\
\text { all public transport services in the area. The transport authority is totally owned by } \\
\text { the County Council. } \\
\text { In Halmstad the regulatory role is played by a transport authority (HT) owned by } \\
\text { the Halland County Council and the municipalities. HT is responsible for all public } \\
\text { transport services in the area of Halland and has the power to grant exclusive } \\
\text { concessions to operators in this region. }\end{array}$ \\
\hline \multicolumn{2}{|r|}{ United Kingdom } \\
\hline $\begin{array}{l}\text { Multilevel } \\
\text { structure }\end{array}$ & $\begin{array}{l}\text { Central government and } 4 \text { constituent nations (England, Wales, Scotland, Northern } \\
\text { Ireland), with different territorial organizations. Commonly, there is a regional } \\
\text { government and one or two tiers of local government. } \\
\text { The Capital enjoys a special status and special powers. }\end{array}$ \\
\hline
\end{tabular}




\begin{tabular}{|c|c|}
\hline $\begin{array}{l}\text { Multilevel } \\
\text { governance of } \\
\text { LPTs }\end{array}$ & $\begin{array}{l}\text { The national government is responsible for railways services (Rail regulator) and } \\
\text { establishes the legislative frameworks for other modes. } \\
\text { Local governments are responsible for LPTs services. The local government act of } \\
2000 \text { has increased the power of local governments to plan and define local public } \\
\text { services, including LPTs. }\end{array}$ \\
\hline $\begin{array}{l}\text { Power of } \\
\text { initiative and } \\
\text { competent } \\
\text { authorities }\end{array}$ & 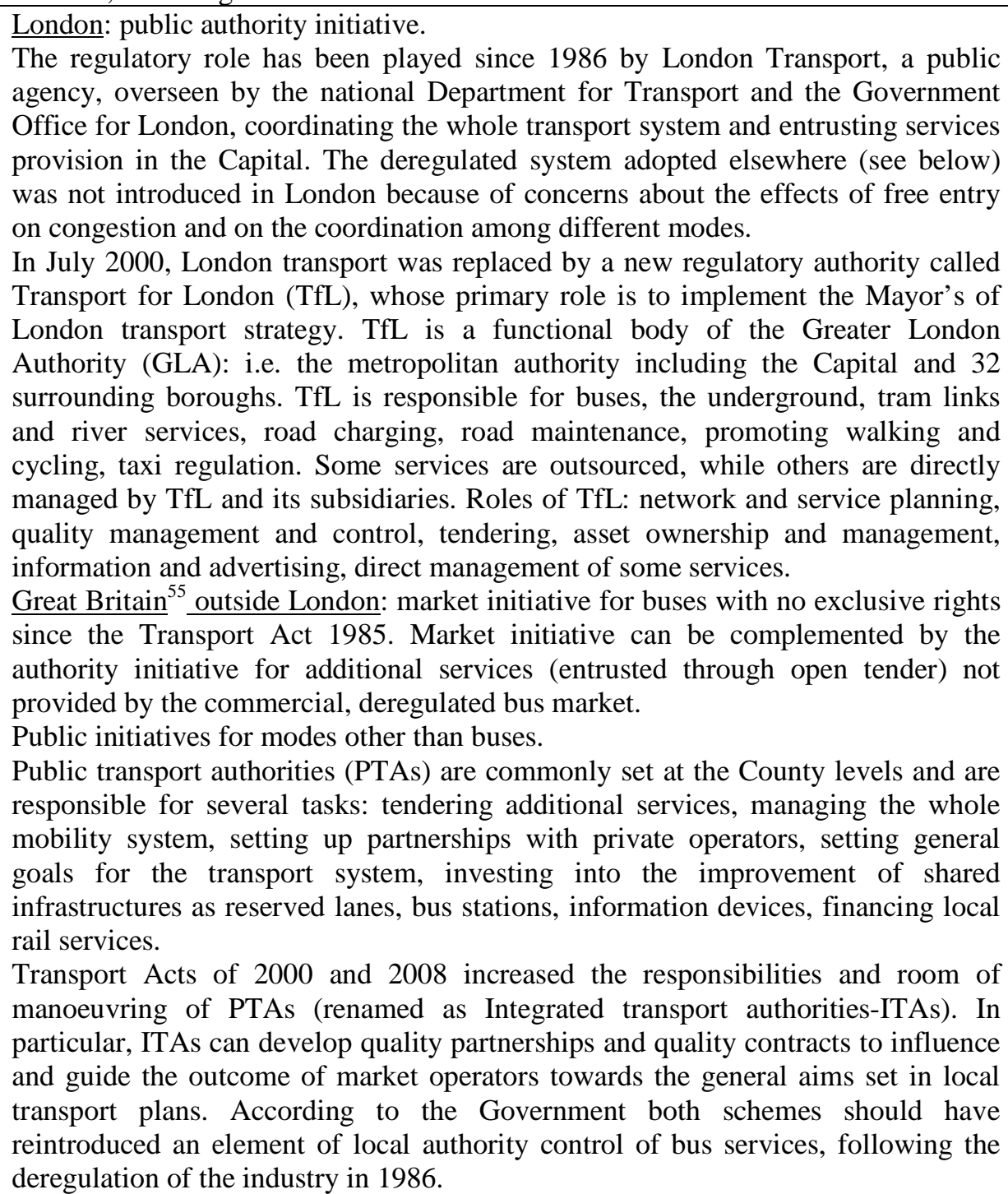 \\
\hline
\end{tabular}

\subsection{Persisting public involvement}

National case studies show that public involvement in the definition of LPT services is still central in the European context: in urban areas, in fact, strategic responsibilities are almost exclusively in the hands of public authorities, that keep the power to influence and steer market structures and outcomes, and no full liberalization process actually occurred. This guiding role, moreover, is not enacted only through forms of light regulation directed to all the market actors

\footnotetext{
${ }^{55}$ Great Britain excludes Northern Ireland that has a partially different model.
} 
(minimum technical and social standards, legal prerequisites, general rules, etc.), but commonly relyies on more intrusive regulatory devices: transport plans, public service obligations, exclusive rights, compensations, control and monitoring.

In six case studies - Belgium, France, Italy, London, Spain, Sweden - the authority initiative is largely predominant, commonly through a monopolistic/monopsonistic power to prescribe and define which services have to be produced. Transport authorities behave in this context as the only (or at least clearly predominant) subject in charge of providing public passenger transport services in urban areas, in the sense that they can either produce services by their own (direct public management), or request their production outside according to predefined planning and design instruments (public authority as contracting authority).

In Austria and Germany (and partially Poland) the market initiative has formally a leading role. Operators can in fact take the initiative to apply for an authorisation for commercial routes, but, as a matter of fact, this bottom up approach never developed and the idea that market initiative is present in a "moribund state" (van de Velde, 2001 p. 17) or that "Germany has indeed become almost identical to a situation where the authority has the legal initiative" ${ }^{56}$ (van de Velde, 1999 p. 152) fully pertains to the present situation. This outcome ensues from a situation where the authorisation regime is dominated by authority owned companies, commonly strongly shielded, as far as their exclusive right to serve the market, by the rules adopted to allocate authorisations, so that few margins emerge for other actors. In a dynamic perspective, even if more flexible and open procedures would be progressively applied, mainly due to the application of the EU R1370, local authorities will still keep a key role to influence the market outcome, defining passenger transport plans (Nahverkehrsplan) that guide the decision when operators request an authorisation or when non profitable routes are tendered (IAU, 2009 and box 4).

${ }^{56}$ Similarly see also Brandt and Shulten (2008). 
Les autorités responsables élaborent un «Plan de transports publics de voyageurs » (« Nahverkehrsplan ») selon leurs compétences : les villes autonomes et districts pour les transports non-ferroviaires, les Länder pour les modes ferroviaires. Du fait de la double casquette de Berlin, à la fois ville et Land, son Nahverkehrsplan intègre tous les modes de transport. Berlin et le Brandenburg ont l'obligation de réaliser un Nahverkehrsplan et de le renouveler, tous les 4 ans pour Berlin, tous les 5 ans pour le Brandenburg. Presque tous les districts et villes autonomes du Brandenburg conçoivent également un Nahverkehrsplan local, bien que ce ne soit plus obligatoire cette échelle.

Le Nahverkehrsplan est l'instrument le plus important de l'autorité responsable pour définir l'offre de transports en commun sur son territoire. Le niveau d'offre défini dans le Nahverkehrsplan est une obligation pour l'exploitant, même si des adaptations sont possibles si l'autorité responsable et l'exploitant sont en accord et si le changement est conforme au contrat entre les deux parties.

Selon la Loi fédérale sur le transport des personnes, tout transport commercial de voyageurs est soumis à l'obtention d'une autorisation. L'objectif de ce règlement est d'assurer la sécurité des voyageurs et de vérifier la fiabilité et le sérieux de l'exploitant.

Il en existe deux types :

- type $\S 13$ (de la Loi) : offre sur proposition d'un exploitant (mais dans le cadre du Nahverkehrsplan), exploitation « risques et périls » (autonomie financière), pas de recours obligatoire à un appel d'offre pour l'attribution du marché.

- type §13a (de la Loi) : offre à la demande de l'autorité responsable (toujours dans le cadre du Nahverkehrsplan), recours à un appel d'offre (sauf exception) pour l'attribution du marché.

Source : IUA (2009 p. 19-20).

Finally, in Great Britain-outside London, the existing open entry regime (market initiative without exclusive rights), established for buses since 1985, is commonly mentioned as an idealtipical case of full de-regulation, or, better, of light regulation (Hibbs, 2009), where public authorities keep a marginal and complementary role with respect to the operators. Actually, the unquestionable move towards a more liberalized environment carried out during the eighties has been more recently characterized by some backwards steps. Since $1997^{57}$, in fact, policy initiatives were adopted to tackle some of the problems linked to deregulations $^{58}$, giving the public transport authority new and higher competences and instruments in order to coordinate and integrate the provisions by private companies ${ }^{59}$ (tendering of social services, quality partnership, quality contracts, special tariffs, etc.).

All things considered, the most recent experiences of European countries seem to confirm that the general interest in LPT (urban) services is still well acknowledged. Public authorities, left free to decide, still retain adequate forms of planning and steering levers to correct market failures. The meagre

\footnotetext{
${ }^{57}$ Following the contents of the new White paper: "A new deal for Transport".

${ }^{58}$ E.g.: loss of patronage, fragmentation, lack of coordination and integration with railways and metro services, withdrawal of services outside core routes, excessive market concentration. On this point: European Commission (1997); Butcher (2010b).

${ }^{59}$ In the words of Hibbs (2009, p. 77): "Since 1997 there has been a growing pressure for reregulation ....Steps toward this were taken in the Transport Act 2000. Now we have the Local Transport Act 2008, which could provide for this to be taken further; a Statutory Contract Scheme would enable the Integrated Transport Authority to remove commercial decisionmaking from bus operators and end all competition. Other parts of the new Act would allow further steps in the same direction".
} 
contribution offered by (authorised) market initiatives in Austria, Germany and Poland and the controversial results brought about by the British deregulated systems make the authority initiative and capacity of coordination a widespread and even growing evidence in case studies ${ }^{60}$, at least as far as strategic decisions are concerned. The statement of the new EU Regulation on transport according to which "at the present time, many inland passenger transport services which are required in the general economic interest cannot be operated on a commercial basis. The competent authorities of the Member States must be able to act to ensure that such services are provided" ${ }^{\prime \prime 1}$ seems therefore to reflect a quite consolidated and established situation.

This circumstance leads the main research interest to shift from that of evaluating market vs. non market initiatives regime, to investigating what forms of new or better regulatory devices are emerging within public management.

\subsection{Decentralization}

Another finding widely emerging from the countries' survey is the increasing attribution of organizational and financial responsibilities to regional and local authorities as far as LPT services are concerned. While, in fact, national governments commonly retain powers on long distance railways services, buses and other track-based modes (metro, tramways and often even short distance railways) have been mostly decentralized to sub-national administrations.

If a higher level of decentralization is strictly consistent with the subsidiarity principle and can better adapt services to the specific territorial needs, stimulating at the same time a higher degree of efficiency, accountability and responsiveness, it can also bring about relevant drawbacks.

On the one hand, in fact, decentralization can be a source of fragmentation, leading to the generation of intermunicipal spillovers, lack of coordination among both different modes and different territorial competent authorities, and even scarce capacity to take advantage of economies of scale (Bird, Slack, 2004). Therefore, it seems therefore important the process of involvement of territorial bodies being adequately accompanied by a new and better design of the boundaries of the overall institutional building. ${ }^{62}$

On the other, if decentralization is coupled with the reduction of national public funds directed to public transport and, more generally, to local authorities, it can limit the ability of local governments to finance the social role of services, thus imposing a major selectivity in the goals pursued (land coverage, frequency,

\footnotetext{
${ }^{60}$ In the same direction Mallard and Glaister (2008), that, dealing with the re-regulatory process occurred in the UK transport sector, remark that "such recent trends towards reregulation have been common across Europe".

${ }^{61}$ Regulation 1370/2007, Whereas (5).

${ }^{62}$ See the following paragraph $\S 4.3$ for some examples.
} 
services for special categories, low fares). Several clues come out from the analysis on the link decentralization-economisation ${ }^{63}$, making it important to better investigate which effects on services provision and organization are due to the changing regulatory environment and which are simply due to the availability of less financial resources.

\subsection{New (and better?) governance: specialization and territorial integration/cooperation}

Within the context of a persisting (and more decentralized) public involvement, the third common trend characterizing European countries concerns the development of new governance structures in local public transport, mainly in terms of specialization and territorial integration.

From the first point of view, local authorities developed more and more specialized functional structures (agencies, syndicates, administrative companies), entitled of a certain degree of operative and even financial

\footnotetext{
${ }^{63}$ In Austria, Hermann (2006 p. 6) observes that "Transport associations are forms of cooperation to optimise the general service of LPT...As a major source of transport funding, the federal government initially was also part of the associations, but has gradually withdrawn with increasing decentralisation".

In Poland, in the post-1989 transition period, the pressure to reduce subsidies from central governments led to a sharp fare increase, with simultaneous erosion in the quality of services, a slowdown in fleet renewal and a progressive deterioration of the supply capacity. The result is that "local governments still fail to allocate sufficient financial means for local public transport. The quantity and the range of investments are insufficient...The carriages are in a very poor condition - most often they are out-dated, worn-out and not adjusted to passenger needs, including disabled persons. As a result, and as car ownership rises, the share of public transport in total transport decreases in most cities, particularly in medium-sized towns" (Jaspers, 2009 p. 23).

In Italy, the resources granted to local governments to finance minimum services increased in the period 1996-2006 by only $9 \%$, against the $27 \%$ rise in the general price index, so that in real terms they have experienced a reduction by $18 \%$ (Osculati, Zatti, 2008).

In Germany, according to Shulten (2006 p. 15), there are several instruments to co-finance services (investment in public transport infrastructure, grants for the transport of special categories, compensation for the deficit, etc.) but "the amount of money available is continuously decreasing due to scarcity of public finances". Moreover, referring to the financial resources of the Federation granted to finance short-distance railways transport, he states that "with reference to the period from 2006 to 2010 reduced financial resources have been decided" (p. 15).

In France it is found that "the State has unilaterally reduced his contribution to the creation of new mass transport ... The new strategic orientations since 2004 changed the financing system of urban public passenger transport with the withdrawal of investment. Local governments tried to raise other sources of finance: direct taxation, price setting or the TTEVersement transport" (Zadra-Veil, 2010 p. 13-14).
} 
autonomy, and designed to carry out in a qualified way (more or less ample) tasks related to the planning and running of transport services ${ }^{64}$.

Actually, transport agencies have been granted various degrees of autonomy and powers to discipline and coordinate the market outcome. In some cases (as, for, example, in the city of Milan), they are purely advisory bodies, in charge of providing technical assistance to political bodies: research, market analysis, monitoring, customer satisfaction surveys, etc. In some other cases, they acquire an intermediate role, becoming directly responsible of some operative and even tactical decisions/tasks - fare and timetable integration, revenue management, contract design and follow up, service awarding, marketing and users' information, quality control and monitoring - within a context where the role of competent authority is still played by political bodies. Many Transport Associations (Verkehrsverbund) in Germany and Austria can be traced back to this intermediate model since they act to integrate the decisions of competent authorities, without replacing them. Finally, there are several examples of "heavy authorities", assuming almost all the relevant levers of service regulation, including service planning and contracting, asset ownership and tariff setting. That is the case of County transport authorities in Sweden, transport syndicates in France, TfL in London, CRMT in Madrid and ZTM in Warsaw. In these latter cases, territorial political authorities delegate the responsibility to plan and manage transport services to the sectoral authority, keeping the highest strategic decisions at the political level (general aims, guidelines, budget resources, social and environmental priorities, etc.).

On the whole, (semi) independent agencies/authorities can represent an important tool to play the (persisting) public role in an effective way and to manage the growing complexity of modern government. In fact, they can allow public powers to maintain and specialize the technical competences and know how accumulated over many years in the self-production regime; and, at the same time, guarantee a higher degree of autonomy with respect to the different actors involved (political powers, users, voters and operators).Yet, this new institutional setting, based on a higher degree of independence, brings about the challenge of making agencies fully accountable to the institutionally recognised and elected branches of government for the regulation they promulgate. With the development of separate regulatory bodies, in fact, a new agency relationship is established at the top of the decisional chain (Fig. 7), requiring to achieve a (demanding) balance between regulatory discretion, on the one hand, and responsiveness, on the other.

\footnotetext{
${ }^{64}$ When such authorities have not been created, the strategic functions are directly carried out by local governments (as in Belgium), or by transport operators more or less steered by political bodies (see below on this point).
} 
Figure 7. Strategic decisional chain with a separate planning body

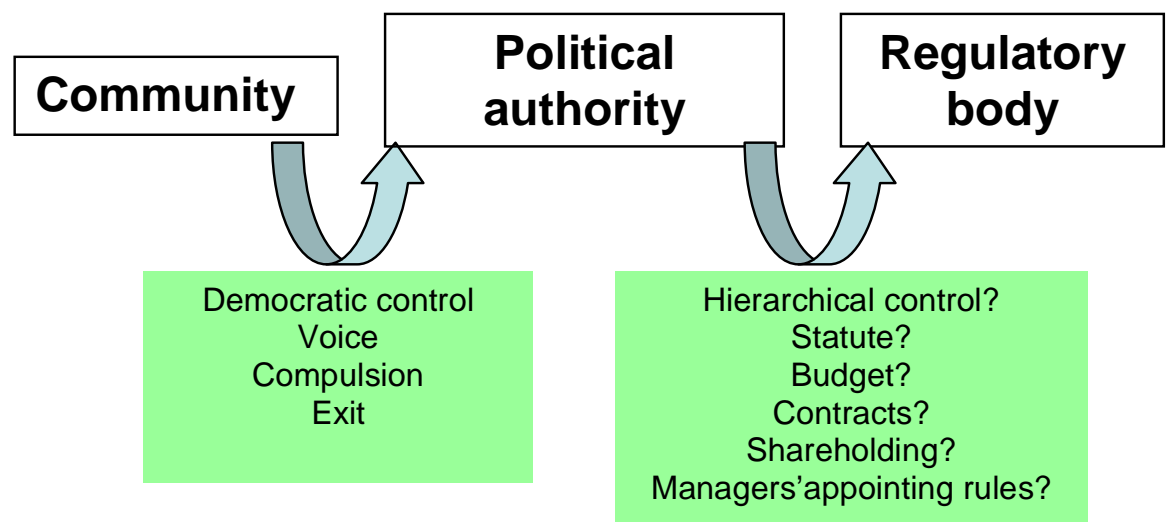

Many different solutions and facets characterize the case-studies on this subject, although two prevailing models can be singled out.

On the one hand, there are bodies that, while provided with a certain degree of operative autonomy and visibility, are still strictly linked and influenced by the public authority (or authorities) by whom they originate. That is the case, for example, of French syndicates, of TfL and other British PTAs, of Spanish consortia or of ZTM in Warsaw ${ }^{65}$, where legal status, administrators' appointing rules, financial relations and tasks assignments can be, to a large extent, traced back to hierarchical and unilateral delegation, i.e. typical features of public administrations. Accordingly, TfL acts as an arm's length body of the metropolitan authority (GLA), under the direct control of the Major and with a straight decisional and financial dependence on the political power; the same applies (by far) to French syndicates and to others British PTAs.

On the other hand, there are several cases where relevant levers of the regulatory power are given to more independent structures, increasingly assuming the status of private law companies tied to the owners by contractual arrangements: Swedish transport authorities, many German Transport Associations, TraffiQ in Frankfurt, IVB in Innsbruck or ATAC in Rome (until 2010) ${ }^{66}$ fit in this model ${ }^{67}$. The employment of stock option or limited liability companies to play the regulatory role is certainly a new and, at the same time, controversial feature: a typically public function, i.e. that of steering service provision towards the general interest, is demanded to an institutional setting traditionally demanded to other goals. The trade-off between autonomy and accountability seems to be particularly acute in this case. The risks of impairing democracy, due to a decrease in political and financial control and transparency, and of favouring fragmentation, in a sector where coordination between public transport and other modes, as well as with other policy areas as spatial planning, is fundamental, are

\footnotetext{
${ }^{65}$ And other polish public transport authorities as those introduced in Cracow and Poznam.

${ }^{66}$ As well as some other transport agencies in Italy.

${ }^{67}$ It is the case of the so called Administrative company described above in Figure 3.
} 


\section{if fact high and require an adequate monitoring of the overall outcome of the on- going trend.}

\section{Table 3. Regulatory authorities in selected case studies}

SYTRAL $^{\mathrm{a}}$ is the transport competent authority for the metropolitan area of Lyon and the Rhone Department (64 municipalities involved).

SYTRAL is responsible to plan services and infrastructure development, to fix fares, to regulate and control quality; it is also the owner of all the assets: vehicles, depots, rolling stock, shelters, and rails.

SYTRAL is a public-law body (établissement public à caractère administratif-EPA ${ }^{68}$ ). Labour relations and budgetary procedures are ruled according to the public law.

SYTRAL is governed by a steering committee of 26 members: 16 elected by the metropolitan government of Lyon and 10 elected by the Department du Rhone. It has an administrative staff of about 80 persons in charge of supporting and executing the decisions of the board.

SYTRAL is financed by three main sources: grants from local administrations, an earmarked tax for transport (Versement transport) and fare and commercial revenues.

$\underline{\mathrm{STIF}}^{\mathrm{b}}$ is the transport competent authority for the metropolitan area of the Ile the France.

The mission of the STIF is to implement the decisions adopted by local authorities within the steering committee.

STIF is a public-law body (établissement public à caractère administratif-EPA). Labour relations and budgetary procedures are ruled according to the public law.

STIF is governed by a steering committee of 29 members: 15 elected by the regional government, 5 by the city of Paris, 1 by each department, 1 by the local Chamber of Commerce, and 1 by the metropolitan cooperative body. The committee is chaired directly by the president of the regional government.

STIF is financed by three main sources: grants from local administrations, an earmarked tax for transport (versement transport) and fare and commercial revenues.

$\underline{\mathrm{TfL}^{\mathrm{c}}}$ is the transport regulatory body for the Greater London Authority (GLA).

$\mathrm{TfL}$ is an agent of the GLA to implement the integrated transport strategy established by the Major. TfL is directly accountable to him. The Major has a very wide power of control over TfL: he is given power to issue guidance and general or specific directions as to the exercise of any of the functions of TfL. The Mayor is also responsible for setting the TfL's budget.

TfL is run by a board of 13 members, all appointed by the Major. The Major may choose to be a member of TfL and, if so, shall be the Chairman.

TfL is a statutory corporation. A statutory corporation is a corporate body created by statute. It typically has no shareholders and its powers are defined by the Act which creates it, and may be modified by later legislation. Common examples of statutory corporations include municipal councils, universities, central banks and government regulators.TfL's legal status is that of a local authority, which ensures that TfL is bound by the Chartered Institute of Public Finance and Accountancy code and government approved borrowing limits as well as being legally obligated to set a balanced budget on an annual basis. Additionally, it must undergo annual external audits and implement 'best value' procedures. Furthermore, the local authority structure imposes statutory obligations upon officers and permits government intervention in cases of mismanagement or financial failure.

$\underline{I V B}^{\mathrm{d}}$ is the competent transport authority in the city of Innsbruck.

IVB acts mainly as an administrative company, planning the network and the services to be offered, and doing marketing, ticketing, customer information, complaints managements, etc. IVB directly runs tram and trolleybus services

IVB is a limited liability company linked to the local government by a management contract. IVB is owned $51 \%$ by the municipal multiservice stock option company, $45 \%$ by the City Council and $4 \%$ by the regional government. The City multiservice company is owned $51 \%$ by the City and $49 \%$ by the regional energy company.

$\underline{Z T M}^{\mathrm{e}}$ is the public transport authority of the city of Warsaw.

ZTM acts according to the Statute set by the Warsaw city Council and according to the law on transport services. ZTM is a budget entity, i.e. a public sector entity without legal personality. The roles of ZTM are directly

${ }^{68}$ En France, un établissement public à caractère administratif (EPA) est une personne morale de droit public disposant d'une certaine autonomie administrative et financière afin de remplir une mission d'intérêt général autre qu'industrielle et commerciale, précisément définie, sous le contrôle de l'État ou d'une collectivité territoriale. 
established by the unilateral act adopted by the municipal council. Tasks of the ZTM are: market research, preparation of transportation offers, maintenance of stations, loops and stops, ticket sales and inspection, entrusting services provision, inspection of transport duties.

$\underline{\text { ATAC }}^{f}$ has performed as the planning agency in the city of Rome up to 2010. ATAC was a stock option company owned by the Municipality and tied to the Municipality itself by a contractual relation.

Since 2010 the regulatory agency merged with the two existing transport operators, to become the only service provider in the metropolitan area. A new Agency has been created (Roma servizi, Limited liability company) with a lighter role, since it has only an advisory function with respect to the transport department.

$\underline{\mathrm{SL}}$ is the regulatory body in the region of Stockholm.

$\widehat{S L}$ is a limited liability company, $100 \%$ owned by Stockholm County Council. SL was the former transport company, later transformed into the public transport authority. SL is governed by a board of selected County Councillors responsible for translating the County's broader transport objectives into detailed operational plans.

Public Transport Authorities in Great Britain are made up of councillors nominated by the Metropolitan Councils.

Each PTA has a passenger transport executive (PTE) which is a separate legal entity. PTEs are responsible for day-to-day administration and are controlled by their respective Passenger Transport Authority.

The PTAs are not fiscally autonomous: every year they have to negotiate a grant with the local authorities in the areas they serve.

${ }^{\mathrm{a}}$ www.Sytral.fr

b www.stif.info

www.tfl.gov.uk and Butcher (2008)

d www.ivb.at

e www.ztm.waw.pl

www.atac.roma.it

Together and along with specialization, public authorities widely adopted initiatives to deal with the (increasing) risks of fragmentation and lack of coordination brought about by decentralization. This attempt is consistent with several studies showing how vertical and horizontal cooperation among administrative units represent a key point for a successful development of collective transport means (ECMT, 2002; Colin Buchanan and Partners, 2003b; van Egmond et al., 2003).

Significant insights can be found in the different solutions adopted.

The first approach has been that of limiting decentralization: i.e. to assign responsibilities to an intermediate level of governments, so that coordination is granted through a mainly top-down perspective. In Belgium, for example, the three regional governments (Walloon region, Flemish region and Brussels region) act as competent authorities, providing services throughout their territories, and favouring integration and the opportunity to exploit economies of scale and scope. A similar situation can be found in Sweden where the regulatory role is set at the County level, that is the intermediate level of government in the existing three tiers institutional setting. In this last case, the involvement of Municipalities at the strategic stage is granted, at least in some Counties (as in the example of Halmstad), by their participation as shareholders within the stock of the transport authority.

The top-down solution prevailed also in London and, more generally, in Great Britain, where a new (upper) level of government, encompassing a fairly large geographic region and lower-tier or area municipalities, has been created. The upper tier has been granted responsibilities for services supposed to provide region-wide benefits, generate externalities and display economies of scale. So 
the Greater London Authority (GLA), established in 1999 and encompassing 32 boroughs and the city of London, got the strategic role in areas such as: air quality, bio-diversity, culture and tourism, economic development, waste, land use and planning, and transportation (Bird, 2004). In this framework, TfL, the separate functional authority of GLA in the transport sector, guarantees both vertical coordination, being responsible for transport services on the whole area, and horizontal coordination, being responsible for both public (buses, subways, trains) and private (roads, taxis, traffic lights, parking spaces, road pricing) transportation.

In other cases, competences have been mainly given to the local level (districts, city districts and municipalities), while bottom-up cooperative arrangements progressively arose, even if with different degrees of extensiveness and through different institutional devices (syndicates, communities of communes, joint agencies, private law companies, etc.). All forms of cooperation, however, generally imply some extent of administrative integration as well as of political linkage in that local governments have representation in the central administrative board.

Voluntary cooperation is well developed above all in France, where various legal types of association and integration exist (Amaral et al., 2009): both in terms of multitasks organizations (urban agglomerations, as in the example of Dijon and Rouen) or in terms of single purpose syndicates (as in the case of Lyon and Paris) that fully acquire the regulatory role on behalf of the participating local governments. Accordingly, less than 1/5 of communes play the competent authority role alone, while urban public transport is considered one of the most important topics of intermunicipal cooperation (Zadra-Veil, 2010).

In Spain an increasing role is acquired by transport syndicates ${ }^{69}$ (Consorcios), designed to overcome the dysfunctions generated by the current pattern of distribution of responsibilities among different authorities (Martin Urbano et al., 2010). Public Transport consortia emerged, on the basis of inter-institutional dialogue, as transport independent agencies in the main urban agglomerations of the country. Partners are mainly local authorities, but the presence of provincial and regional governments (and even of the State, as in the case of Madrid) is diffused; also private operators and socio-economic partners take part in (some) syndicates (Figure 8). Transport syndicates (both in France and in Spain) generally play a "strong role", as in the case of Madrid or Paris, since most of them have responsibilities on the main regulatory functions: spatial planning, financial planning, tariff regulation, infrastructure construction, service provision and service evaluation. Accordingly, they are paradigmatic examples

\footnotetext{
${ }^{69}$ The number of inter-municipal transport authorities increased from 4 in 1997 to 18 in 2007 (Martin Urbano, 2010).
} 
of new forms of governance, voluntarily adopted to meet the need for coordination of the complex phenomenon of mobility.

Figure 8. Spanish transport syndicates by partners' share (2007)

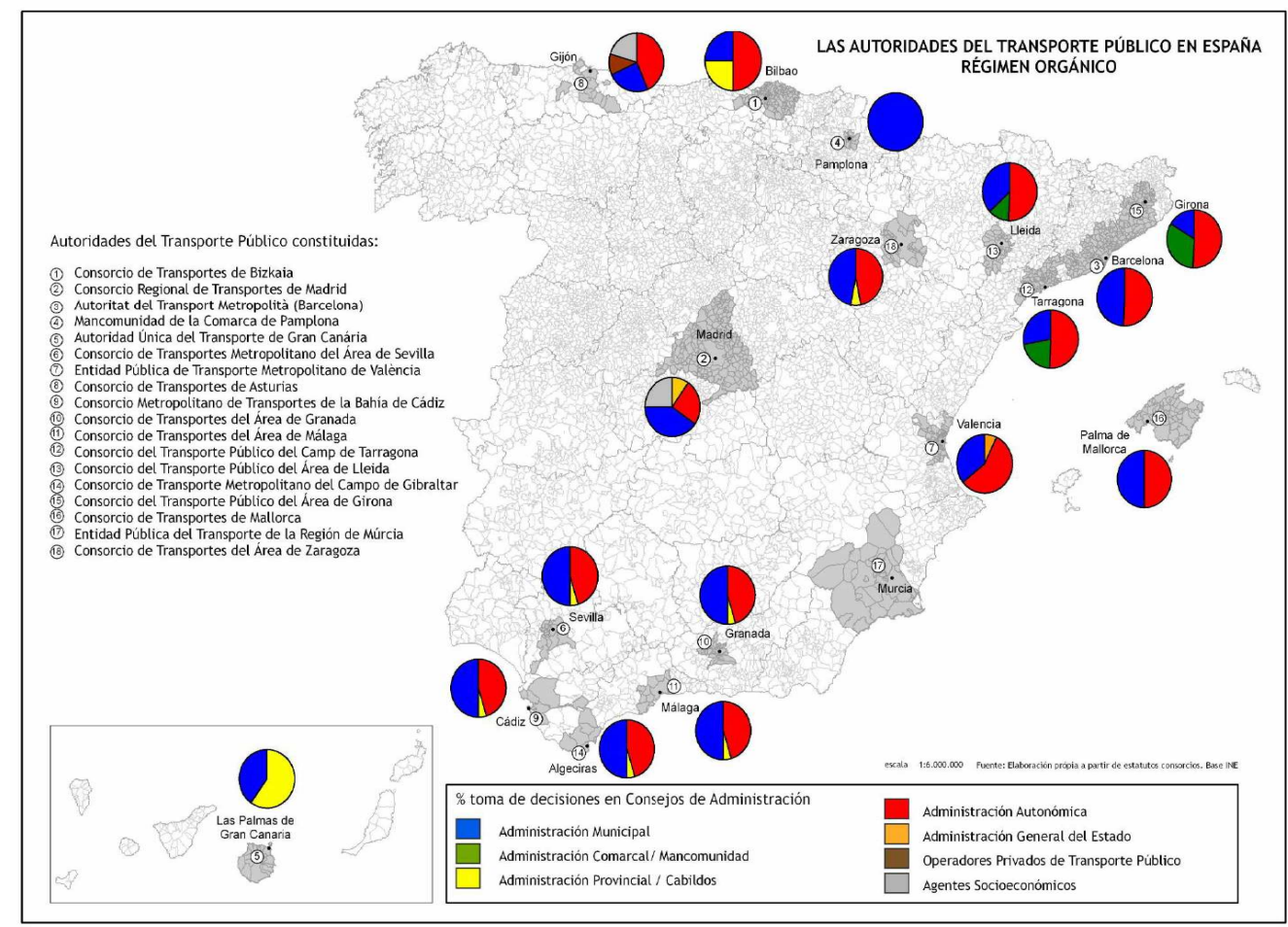

Source: Martin Urbano (2010).

In Austria and Germany, starting in the 1960s, almost every metropolitan area progressively took part to regional transit organizations (Verkehrsverbunds) to coordinate all aspects of public transport operations and ticketing within the region. Verkehrsverbunds are commonly participated both by landers, districts, city districts and operators, permitting a high degree of coordination, both among territorial competent bodies and among modes. They can also provide for a certain degree of independence from the single political body. Such initiatives are deemed to have been largely successful, expanding and improving services and attracting large increases in passengers (Buehler, Pucher, 2011); for this reason, coordination in Germany is directly supported by the federal government which grants annual subsidies that help cover the additional costs of regional initiatives.

In Italy and Poland, measures aimed at the coordination of transit services have been scant and many approaches coexist. In Italy, for example, it can be found a regional government playing the regulatory role for the whole transport system $^{70}$, so as municipalities managing services only within their single

\footnotetext{
${ }^{70}$ It's the case of Friuli Venezia Giulia Region, where regional authorities plan services within 4 different basins, entrust and manage contracts and quality control.
} 
territorial borders (as in the case of Rome or Genoa); in few cases, cooperation has been developed through voluntary inter-municipal agencies (Turin, for example), while more frequently some form of territorial integration has been obtained through the progressive extension of services from the central city to the surrounding communes, mainly due to the action of the locally owned public operator (Milan, Florence, Naples). In Poland cooperation is an exception, and fragmentation is seen as a serious threat: "under present market as well as formal and legal circumstances there are no solutions enabling creating an integrate offer" (Grzlec et al., 2009).

All in all, the placement of the regulatory role in the multilevel government represents an open question and even a critical issue. The positive aspects of more centralized and integrated solutions - better physical and functional coordination of services, scope and scale economies, technical specialization, room for yardstick competition, higher level of autonomy and independence vis a vis local interests - must be oughtweighted with possible drawbacks in terms of excessive proliferation of government organizations, lower capacity of adaptation to local circumstances, reduced accountability and transparency with respect to local communities. In Germany, for example, the regulatory role is shared between the local level and regional transport associations, so that it is not easy for the citizens to understand the true responsibility for service provision; the same applies for the city of Barcelona where both a metropolitan (18 local authorities) and a greater metropolitan authority (164 local authorities) coexist, with a continuous redefinition of their respective roles (ECMT, 2002). Even where a regional body with a clear political mandate has been created (London) some problems of autonomy and representativeness for local communities (boroughs) materialize (ECMT, 2002). The capacity to find out a correct balance between subsidiarity and effective territorial setting represents one of the major challenges of the present evolutionary path.

\section{Regulation of LPT services: towards a common organizational form?}

The widespread recognition of the general interest in LPT services causes that at least some of the strategic levers are kept within the public sphere, mainly at the local/regional level and with changing institutional and governance approaches. Within this framework, the further investigation of the organizational forms assumed by the public regulation (see Annex 1 for case studies reports) confirms that the starting point of public intervention, almost everywhere characterized by the overseeing of the whole process of service provision by public authorities 
and the complete absence of market pressure along the different stages of the production chain $^{71}$, somehow changed in the last decades.

At the same time, it seems clear that this process did not produce a new dominant paradigm. The changing regulatory environment, triggered by the driving forces already considered in $§ 2.3$ (see box 2), amplified differences in organizational regimes, bringing about significant disparities from country to country, and even from city to city. As a matter of fact, the actual organizational forms implemented in the selected countries exhibit much more variety than supposed under a common "europeanisation process" and require more complex analytical approaches.

In what follows, we will try to investigate to what extent and in what direction the main evolutionary paths have taken place and, in particular, how much of the decisional levers has been effectively delegated outside the competent public authority.

\subsection{Organizational forms: a tentative categorization}

Even if nuances and diversities come out in each single national report, some defined organizational models can be singled out.

\section{Belgium model-Self owned company with developing sub contracting}

Belgium can be seen as a term of reference of a "minimum change" approach, where "Le choix a été fait de garder les opérateurs dans le giron public" (Goethals, 2010 p. 30). Three monopolistic operators - public (regional) entities under public law and public budget - provide local transport services under exclusivity within their respective regional areas. Operators are linked to the corresponding regional government (that is also the owner) by contractual arrangements, including obligations related to the quantity and quality of services to be provided, as well as commitments by the authority as to the budgets available to the operator itself. Despite the progressive development of contracts, the separation of roles authority/operator is weak and ambiguous so that, as a matter of fact, operators keep relevant tactical and even strategic responsibilities: "de simple exploitant, rôle désiré à l'origine par les pouvoirs publics, l'opérateur devient un manager de la mobilité a l'échelle de la Région" (Goethals, 2010 p. 9). Public operators are formally submitted to both operating and revenue risks, but they commonly rely on soft budget constraint so that a true risk sharing between internal and external actors does not exist ${ }^{72}$. In this

\footnotetext{
${ }^{71}$ Corresponding to the "Direct public management-Self production regime" described in $\S 2.2$ and Figure 2.

72 «En Belgique, les opérateurs supportent en grande partie les risques liés aux coûts et aux revenus. Il convient néanmoins d'apporter certaines nuances. En Région bruxelloise, le
} 
model, the whole decisional chain is shared between regional governments and public companies, with the latter strictly controlled by the former, so that the self-production regime (left extreme A in Figure 2) seems actually not so remote.

Alongside this pure "Belgium model", in the last decades there has been an increasing recourse to sub-contracting of the operational tasks to private operators in Wallonia (30\%, without tendering) and in the Flemish region (45\%, mostly through tendering). Public companies are in charge of a growing administrative and regulatory role, while they leave space to private independent undertakings at the lower stages of the production chain, where the principalagent relationship takes place. Private operators are mainly small entities (family companies) generally operating under gross cost contracts and with no freedom in services design and no commercial risk assumption. The system currently emerging in the Flanders is a model of indirect tendering, where the public in house operator (De Lijn) increasingly acts at the same time as provider, planner, purchaser and regulator (Fig. 9). However, it is the Flemish government that determines the percentage of the total exploitation that has to be entrusted to a third party. The idea is to keep part of the supply in-house so as to maintain production expertise and bargaining power in case of possible oligopolies or the necessity to in-source part of the network.

Figure 9. Indirect tendering in the Flemish region

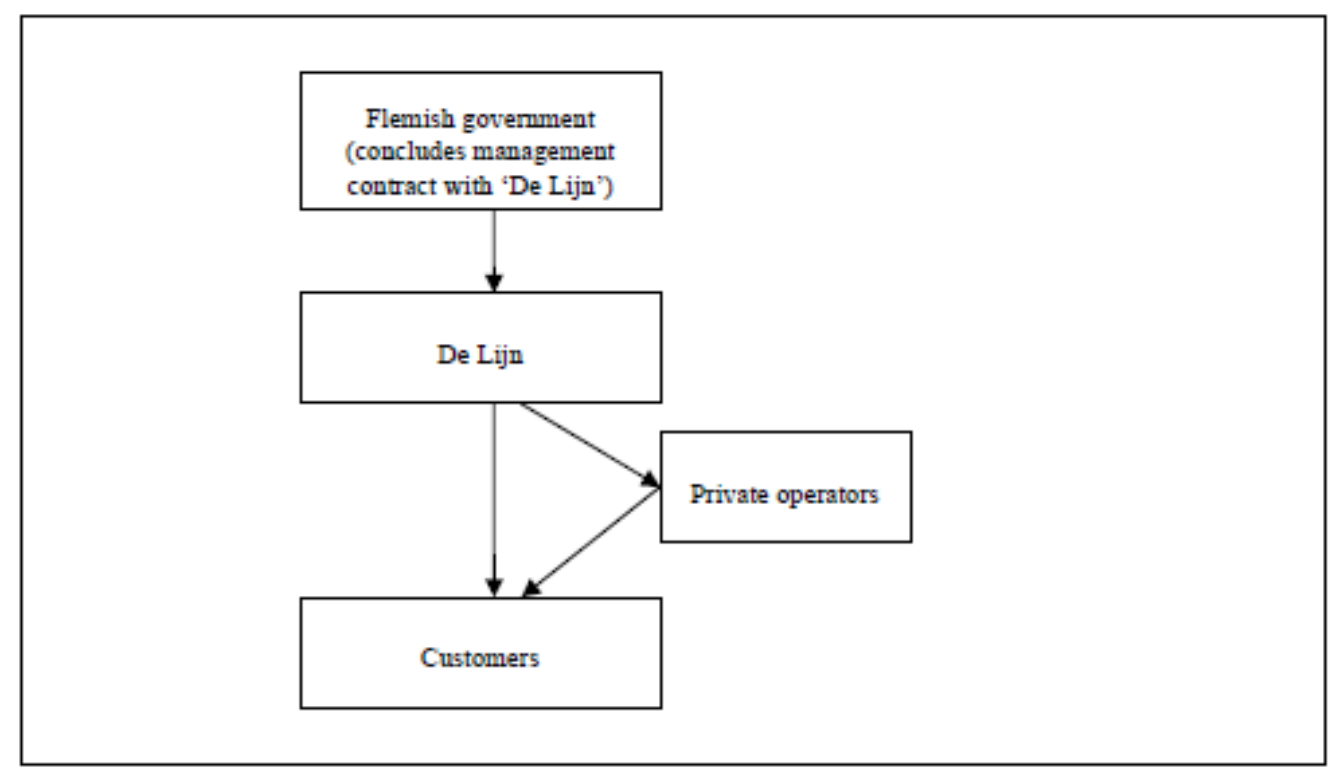

gouvernement envisage par exemple de reprendre à sa charge la dette de l'opérateur. S'il est bien légitime de vouloir assainir les finances de la STIB pour repartir sur de meilleures bases, il s'agit néanmoins ici d'une forme de reprise du risque, à charge de l'organe de tutelle. Cette reprise du risque peut amener, si elle se produit de manière récurrente, à une déresponsabilisation de l'exploitant qui enlèverait par la même occasion une grande part du caractère incitatif du contrat de gestion »(Goethals, 2010 p. 7). 
To the other extreme with respect to Belgium, the GB-outside London model is often considered in Europe an almost unique case of deregulated-free market system (right extreme D in Figure 2). In fact, since the Transport Act 1985 removed the duties of local authorities to co-ordinate LPT services in their area, a decisive space has been given to the open entry regime. Accordingly, territorial competent bodies (Public Transport Authorities-PTEs) have lost most of their former powers, while bus companies can get permanent non-exclusive licences and are free to choose the routes they want to operate according to their commercial profitability. Privatization has been seen as a necessary step to be coupled with deregulation to achieve a more committed management and better access to private capital. As a result, the 1985 act required the sale of the national Bus Company subsidiaries to the private sector, and, at present, five big private operators dominate the market.

However, even in this open entry-model, PTEs still retain some levers to influence the market outcome: tendering of non commercial routes, granting subsidies for special categories (pensioners, students, disabled, etc.) or territorial contexts (outskirts, rural areas, etc), and even signing partnerships or contracts to influence market operators (box 5 for details). It is widely acknowledged (Hibbs, 2009; Brujnes, 2009; Butcher, 2010b) that these re-regulatory devices, mainly introduced by the Labour Government, are causing an increasing level of intrusiveness and public involvement. In theory, through social services and quality contracts, they can lead to the replacement of open competition with a different regime, where operators bid for exclusive rights to run bus services on a route or group of routes, on the basis of a local authority service specification and performance targets (Butcher, 2010a). And meanwhile: "the level of subsidy (i.e. bus service operators' grant, public transport support and concessionary fare reimbursement by local authorities) for bus services increased dramatically after 1997" (Buthcher, 2010c p. 1)....

All in all, it seems that the clear shift towards the open entry regime occurred during the 80 s has been more recently replaced, or at least complemented, by some steps in the opposite direction. Public authorities are progressively reacquiring a major role in influencing market outcome. This trend is however in progress and some of the implemented instruments are only at the embryonic stage (for example quality contracts) so that the prevailing landing places are still uncertain. 


\begin{abstract}
Box 5. Initiatives and instruments of re-regulation in the Britain Bus System
Through quality partnership, the local authorities can integrate the transport systems with services and infrastructures exploitable by all operators: information devices, shelters, intermodal stations, reserved lines etc. On their own, operators of local services that wish to use those facilities agree to provide services of a particular quantitative and qualitative standard (new vehicles, low floors, staff training, etc.). Quality partnerships must be fair and open (i.e. all operators are entitled to be partner so long they meet the necessary standards), and must follow a formal consultation of all the operators that can use the facilities involved. The Local Transport Act 2008 increased the opportunity for local authorities to influence market operators' behaviours manly through two devices: schemes are able to include new services' characteristics such as service frequency, timings and maximum fares; local transport authorities are given the opportunity to impose restrictions on the registration of certain local services where the authority considers that the provision of additional local services in the area may be detrimental to the provision of service under the agreed quality scheme.

Since the Transport Act 2000, public transport authorities have been also entitled to enter into quality contracts for bus services. Under a quality contract, the local transport authority determines what local services should be provided in the area (including routes, timetables and fares) and lets contracts with bus operators, granting them exclusive rights to provide services to the authority's specification. The application by a local authority to adopt quality contracts for all or part of its services is subject to the ministerial approval: the local public authority must demonstrate that the results and objectives included in its Local Transport Plan could not be met by other means and that extra costs involved would be offset by benefits. Local Transport Act 2008 has increased the opportunity for local authorities to develop quality contracts and to overcome the problems encountered in their implementation.

The Transport Act 2000 made easier for local authorities to subsidise additional services. It removed the constraint that in exercising that powers local authorities must not act so as "to inhibit competition", requiring more generally to have regard to the interests of the public and of operators.

Since 2001 the Central Government introduced a pass for older people and some groups of disabled people throughout England and Wales which entitled them to at least half fares during off-peak travel, although local authorities can provide greater concessions. The concession was extended to free travel on local services from 1 April 2006.

Since 1998 a rural bus subsidy grant is paid to local authorities to help support the provision of non-commercial rural services and is targeted to support accessibility in rural areas.
\end{abstract}

Source: elaborations on Butcher (2010a).

Swedish (Scandinavian) model-Detailed competitive tendering with strong regulatory bodies

The three distinguishing features of the Swedish model ${ }^{73}$, applicable also to the London case study, are: wide recourse to competitive tendering, development of strong regulatory bodies (frequently arisen from the ashes of the former monopolistic local provider) and high degree of privatization of the operators. Tenders are mainly based on route-by-route (or small bundles) contracts, with limited discretion for the operators. Accordingly, gross cost contracts progressively replaced net cost contracts, since the division of service planning responsibilities between operator and transport authorities leaves few opportunities to the former to influence services attractiveness. In Sweden, PTAs own the main infrastructures and essential facilities, so that contestability is highly enhanced; in London, instead, depots and vehicles are owned by operators, with a potentially restrictive effect on competition.

\footnotetext{
${ }^{73}$ Often referred to as the "Scandinavian model", as also Norway, Finland and Denmark show similar characteristics.
} 
In both cases, separated public bodies with a high standard of competences have been established to play the regulatory role and to procure services. These "Administrative companies" are linked to the local governments by contractual (Swedish transport authorities) or more hierarchical (TfL) relationships, and play a key role in the definition of tactical and even strategic decisions. With respect to the Swedish case, TfL keeps higher direct managerial and operative capacities so that benchmarking is easier and in-sourcing is possible in case of unsuccessful entrustment to external providers (as occurred for the Croydon tramlink). Moreover, TfL is responsible for a wider variety of policies concerning urban mobility (parking management, road pricing, non motorized means, etc), thus lessening risks of administrative fragmentation.

Private operators dominate bus services and often manage (after tendering) short distance railways and several other truck-based services. Privatization developed gradually in both circumstances, through the progressive privatization of former monopolistic operators and the increasing market opening to foreign suppliers. Meanwhile, market concentration took place and smaller companies have been taken over by larger ones.

As a whole, even if the term "deregulation" is sometime unduly associated to the Scandinavian experience ${ }^{74}$, an organizational form based on exclusive authority initiative, the crucial role of the transport authority, the detailed description of the services to be tendered, and the modest (and declining) assumption of revenue risks by private market operators, cannot be realistically traced back to this model. It clearly comes out, in fact, how the main regulatory levers at the strategic and tactical levels are reserved to public authorities, so that the principal-agent relationship with external operators occurs only at the lower stages of the decisional chain, where the openness of the delegation is highly circumscribed. A model between sub-contracting (B.1.1) and detailed delegation (B.2.1), and certainly far away from the deregulated right option. French model (outside Paris) - Network tendering with higher service design
freedom/responsibility

The French model outside Paris is based on local authorities (manly urban agglomerations or transport syndicates) delegating service provision to external operators through tendering. With respect to the Scandinavian case, however, some distinguishing features come into evidence.

Firstly, network tendering is preferred: the whole urban or metropolitan network is commonly entrusted to a single provider with the possibility for him to subcontract part of the services. This regime gives operators more freedom in service design (above all within a negotiation process) and, accordingly, makes

\footnotetext{
${ }^{74}$ Ongkittikul (2010), for example, referring to the Swedish experience, states that "Deregulation came into force in 1989, when all earlier road licenses were abolished".
} 
them bear a higher degree of revenue risks (net cost contracts are actually prevailing).

Secondly, entrusting procedures are less standardised and rigid, combining both competitive bidding and negotiation contents. Given that the assessment of the most suitable bidder for a whole network is complex, the final decision cannot rely only on quantitative methods. Accordingly, local authorities keep higher discretional power during the process, through the adoption of informal discussion on the proposed alternatives, and even relying on criteria including subjective elements such as reputation or confidence.

Thirdly, dominant market operators are mainly public companies, owned or at least controlled by a public entity different from the competent authority delegating the LPT provision. In this model, therefore, the separation of roles is granted even within a predominantly public ownership structure. The same applies to Paris where the transport syndicate among local governments (STIF) directly awards services to two state owned companies. It can be supposed on this point that large national champions (mainly public owned) are resulting as the prevailing market outcome of a system where operators are given large operative and commercial responsibilities.

Finally, factors underpinning contestability are partially different with respect to the Swedish regime. On the one hand, in fact, transport authorities commonly own assets, infrastructures and even vehicles, so that market barriers due to the ownership of essential facilities are minimal. On the other hand, the large scale of transport basins, the opacity of bidding procedures, the highest risk assumption required to the operators and the traditional nationalistic approach adopted on public utilities make the overall degree of market openness quite limited. As a result, concentration of suppliers is elevated and a high rate of renewal of incumbent operators after tendering (>80\%) can be found.

\section{Ambiguous model-De jure vs. de facto market organizations}

The other case studies taken into consideration in this analysis (Austria, Germany, Italy, Poland and Spain) are hardly traceable back to a well defined or at least coherent model. While, in fact, separation of competences, competitive tendering and even bottom up approaches are formally key principles of the normative framework, real market de-integration and contestability are hampered by legal, administrative and political barriers. The overall result is that these national experiences, massively different from a de jure perspective, do indeed resemble to each other in the de facto market outcome, as in most cases municipal operators provide the largest part of the services. Similarly to the Belgium model, self owned companies prevail; however, in these cases the market outcome seems more an unintended effect of political and economic forces (and barriers), rather than the result of an explicit determination to keep the decisional chain within the public administration (as in Belgium). 
Austria and Germany show a similar state of art. While, in fact, market initiative by transport entrepreneurs represents the legal principle for commercial routes (to be complemented by competitive tendering for subsidized ones) the ambiguous definition of subsidies, together with the defensive approach accorded to the incumbent, cause the exclusive direct authorization to municipally owned companies, through renewal, to be the prevailing organizational form in urban services. Accordingly, self owned companies plan, build and operate the urban network through formal or informal agreements, within an institutional setting where service planning tasks and risk sharing are often opaque. Competitive tendering is mainly implemented in rural areas and suburban districts to complement the core provision granted by municipal companies. When direct tendering (as in Frankfurt, in Munich suburbs or German railway services) and even sub-contracting (as in Vienna or Gifhorn) are implemented, the competent authority keeps all the strategic and tactical levers, while contracts are mainly gross cost contracts; in few cases (Frankfurt and Innsbruck) the local incumbent operator has been progressively transformed into an administrative company with regulatory tasks. Finally, the role of privatization remains marginal: medium and small private companies operate mainly on the interurban network or sometimes as sub-contractor (e.g. Vienna), accounting for a small market share.

An analogous situation is found in Poland where, in principle, the local bus transport market is a deregulated market. Transport services may be offered by any operator meeting technical requirements set by sectoral regulations and formal rules related to the access to the profession. However, in practice the largest part of services are directly provided (budget companies) or by locally owned commercial companies, while the contribution of market initiatives is limited to small villages and rural areas. The biggest competition barrier on the local market is the access to bus stations (and even bus stops), since they are commonly owned by the incumbent local companies. Competitive tendering is developing to serve some complementary routes in large urban areas, mainly where transport authorities have been established to play the regulatory role, but its overall role is still marginal. The presence of private operators has been also moderate, limited to fill in the gaps left by municipal companies.

The Italian experience is even more controversial. Although competitive tendering has been formally established by law as the ordinary entrusting mechanism, its effective development has been continuously postponed and hampered by economic and political barriers. As a result, direct management of services by municipally-owned (private law) companies is the predominant choice in the largest urban areas (Rome, Milan, Turin, Naples, Bari, and Palermo). Meanwhile, where tenders have been implemented - nearly $20 \%$ of the whole network, mainly in the north and in the first part of the decade (20002004) - in the majority of cases the incumbent operators won the bid to serve the whole network (alone or with partners). Accordingly, the role of private 
operators is marginal and generally restrained to minority sharing of the local incumbent's stock. As a whole, the local approach to regulation, influenced by the strict existing relationship between the buyer/regulator and the incumbent provider, undermined the credibility of auctions; while, at the same time, the declining public support for urban transport favored local public companies that can rely on softer budget constraints. The overall framework is characterized by an opaque separation of roles and risks, and by a de facto market organization far away from what originally planned by the law.

Finally, in Spain, although the implementation of contracts and the development of transport syndicates somehow improved the separation of roles, the presence of large municipally owned companies brings about the overlapping of competences, hindering the perspective of making markets more contestable. At present, direct management by municipally enterprises largely prevails, while tenders are exploited in few territorial contexts and in sub-urban districts.

\subsection{Towards a more liberalized market structure: to what extent?}

As shown in the methodological premise, liberalization can be interpreted as a process of de-integration of public intervention, through which self-production evolves towards new regulatory forms where tasks and responsibilities are shared between internal and external actors and competition is introduced at a certain stage of the production process. Four main aspects characterize this process - separation of roles, service design responsibilities, risk assumption and contestability - with the first one assuming a higher hierarchical role. Table 4 includes the main findings on these issues emerging from the case studies. 
Table 4. The four dimensions of liberalization in the selected case studies

\begin{tabular}{|c|c|c|c|c|c|}
\hline & Separation & Service design & $\begin{array}{c}\text { Risk } \\
\text { assumption }\end{array}$ & Contestability & Overall \\
\hline Austria & $\begin{array}{l}\text { Low } \\
\text { The biggest share of large } \\
\text { networks is still managed by } \\
\text { companies owned by the } \\
\text { competent authority. } \\
\text { Transport associations can give a } \\
\text { contribution to increase the real } \\
\text { split between planning and } \\
\text { operations. }\end{array}$ & \begin{tabular}{l}
\multicolumn{1}{c}{ High } \\
Public owned companies \\
hold important tactical and \\
strategic decisions.
\end{tabular} & $\begin{array}{l}\text { High } \\
\text { Companies usually share } \\
\text { operating and commercial } \\
\text { risks }\end{array}$ & $\begin{array}{l}\text { Low } \\
\text { Defensive approach granted } \\
\text { to the incumbent operators } \\
\text { Tendering developed only on } \\
\text { additional and complementary } \\
\text { routes, as well as in some } \\
\text { regional rail services. }\end{array}$ & $\begin{array}{l}\text { Low } \\
\text { De-integration is low and } \\
\text { the contribution of } \\
\text { external operators limited. } \\
\text { Transport associations } \\
\text { represent an opportunity } \\
\text { to strengthen higher de- } \\
\text { integration }\end{array}$ \\
\hline \multicolumn{6}{|l|}{ Belgium } \\
\hline Pure model & $\begin{array}{l}\text { Very low } \\
\text { (Strategic and tactical) } \\
\text { The whole decisional chain is } \\
\text { shared between regional } \\
\text { governments and public } \\
\text { companies strictly controlled by } \\
\text { them. }\end{array}$ & $\begin{array}{l}\text { High } \\
\text { Public owned companies } \\
\text { hold important tactical and } \\
\text { strategic decisions. }\end{array}$ & $\begin{array}{l}\text { High } \\
\text { Companies usually share } \\
\text { operating and commercial } \\
\text { risks }\end{array}$ & $\begin{array}{l}\text { Very Low } \\
\text { No contestability is provided } \\
\text { in the pure model }\end{array}$ & $\begin{array}{l}\text { Very low } \\
\text { Minimal de-integration } \\
\text { and none competition } \\
\text { occur in the pure model }\end{array}$ \\
\hline $\begin{array}{l}\text { Indirect } \\
\text { tendering }\end{array}$ & $\begin{array}{l}\text { High } \\
\text { True separation happens when } \\
\text { sub-contracting to private } \\
\text { operators is carried out (Wallonia } \\
\text { and Flanders). }\end{array}$ & $\begin{array}{l}\text { Very low } \\
\text { No freedom in the service } \\
\text { design for sub-contractors. }\end{array}$ & \begin{tabular}{l}
\multicolumn{1}{c}{ Very low } \\
Small and very small private \\
sub-contractors only assume \\
operating cost risks
\end{tabular} & $\begin{array}{l}\text { Medium } \\
\text { Competitive tendering only } \\
\text { implemented in one region } \\
\text { and just for operative tasks. }\end{array}$ & $\begin{array}{l}\text { Low } \\
\text { De-integration occurs at } \\
\text { the operational level with } \\
\text { sub-contracting }\end{array}$ \\
\hline France & $\begin{array}{l}\text { High } \\
\text { In the main part of the network, } \\
\text { services are entrusted to a third } \\
\text { body independent from the } \\
\text { competent authority. }\end{array}$ & $\begin{array}{l}\text { Medium } \\
\text { Operators commonly keep } \\
\text { some responsibilities in the } \\
\text { service definition, above all } \\
\text { during the negotiation stage }\end{array}$ & $\begin{array}{c}\text { Medium/high } \\
\text { Net costs contracts } \\
\text { prevailing and increasing }\end{array}$ & \begin{tabular}{l}
\multicolumn{2}{c}{ Medium } \\
Competitive negotiated \\
tendering \\
implemented to entrust \\
services. \\
Few large groups dominate \\
the market of tendered \\
services with low mobility of \\
providers
\end{tabular} & $\begin{array}{l}\text { Medium } \\
\text { De-integration occurs at } \\
\text { an intermediate level of } \\
\text { the decisional chain with } \\
\text { some tactical devolution } \\
\text { to external operators. }\end{array}$ \\
\hline Italy & $\begin{array}{l}\text { Low } \\
\text { The largest part of the big } \\
\text { networks is still managed by } \\
\text { companies owned by the } \\
\text { competent authority. }\end{array}$ & \begin{tabular}{llr}
\multicolumn{2}{c}{ High } \\
Municipally & owned \\
companies hold & important \\
tactical & and & strategic \\
decision. & & \\
\end{tabular} & $\begin{array}{l}\text { High } \\
\text { Vertically integrated public } \\
\text { transport operators } \\
\text { commonly assume (at least } \\
\text { partially) both operative and } \\
\text { revenue risks (net cost } \\
\text { contract are prevalent) } \\
\end{array}$ & \begin{tabular}{l}
\multicolumn{1}{c}{ Medium/low } \\
Tenders implemented only on \\
around $1 / 5$ of the network \\
Selecting mechanisms favor \\
the incumbent
\end{tabular} & $\begin{array}{l}\text { Low } \\
\text { De-integration is low and } \\
\text { the contribution of } \\
\text { external operators is } \\
\text { limited. }\end{array}$ \\
\hline Germany & $\begin{array}{l}\text { Low } \\
\text { The biggest share of large } \\
\text { networks is still managed by } \\
\text { companies owned by the } \\
\text { competent authority. } \\
\text { Transport associations can give a } \\
\text { contribution to increase the real } \\
\text { splitting between planning and } \\
\text { operations }\end{array}$ & 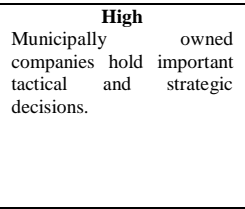 & $\begin{array}{l}\text { High } \\
\text { Vertically integrated public } \\
\text { transport operators } \\
\text { commonly assume (at least } \\
\text { partially) both operative and } \\
\text { revenue risks }\end{array}$ & \begin{tabular}{l}
\multicolumn{1}{c}{ Low } \\
Defensive approach granted \\
to incumbent operators \\
Tendering only developed on \\
additional and complementary \\
routes, as well as in some \\
regional rail services.
\end{tabular} & $\begin{array}{l}\text { Low } \\
\text { De-integration is low and } \\
\text { the contribution of } \\
\text { external operators is } \\
\text { limited. } \\
\text { Transport associations } \\
\text { represent an opportunity } \\
\text { to stimulate higher de- } \\
\text { integration. }\end{array}$ \\
\hline $\begin{array}{l}\text { GB } \\
\text { (London) }\end{array}$ & $\begin{array}{l}\text { High } \\
\text { Clear-cut separation of roles at the } \\
\text { operational level. }\end{array}$ & \begin{tabular}{ll}
\multicolumn{2}{c}{ Low } \\
Detailed & contracting for \\
small & scale networks \\
prevails. &
\end{tabular} & $\begin{array}{l}\text { Low } \\
\text { The large majority of } \\
\text { contracts is gross-cost. } \\
\text { Operators only bear the } \\
\text { production risk, while the } \\
\text { authority carries the revenue } \\
\text { risk. }\end{array}$ & 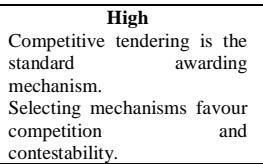 & $\begin{array}{l}\text { Low/Medium } \\
\text { Separation is well } \\
\text { established, but only at the } \\
\text { lower levels of the } \\
\text { production chain. }\end{array}$ \\
\hline $\begin{array}{l}\text { GB } \\
\text { (Outside } \\
\text { London) }\end{array}$ & $\begin{array}{l}\text { High } \\
\text { The separation between } \\
\text { regulatory authorities and } \\
\text { operators is clear both for } \\
\text { commercial and social services. }\end{array}$ & $\begin{array}{l}\text { Medium/High } \\
\text { Market operators are } \\
\text { usually free to decide the } \\
\text { service design and } \\
\text { characteristics (commercial } \\
\text { services). } \\
\text { Quality partnerships and } \\
\text { contracts can influence the } \\
\text { service design. } \\
\text { Around } 1 / 5 \text { of the services } \\
\text { are tendered by transport } \\
\text { authorities through small } \\
\text { scale contracts. }\end{array}$ & $\begin{array}{l}\text { Medium/High } \\
\text { Operators assume all the } \\
\text { risks On commercial routes. } \\
\text { Public authorities commonly } \\
\text { share revenue risks with } \\
\text { operators on tendered routes. }\end{array}$ & $\begin{array}{l}\text { Medium/high } \\
\text { Free market entry entails a } \\
\text { high level of market } \\
\text { contestability. } \\
\text { Deregulated bus market is } \\
\text { dominated by } 5 \text { big operators, } \\
\text { often running monopolies } \\
\text { within a single area. }\end{array}$ & 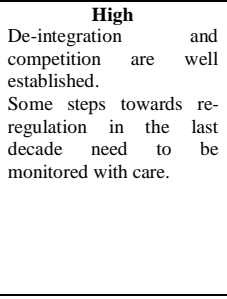 \\
\hline Poland & $\begin{array}{l}\text { Low } \\
\text { The largest part of the services is } \\
\text { provided directly (budget } \\
\text { companies) or by a locally owned } \\
\text { commercial company. }\end{array}$ & $\begin{array}{l}\text { Medium/High } \\
\text { Public owned companies } \\
\text { hold important tactical and } \\
\text { strategic decisions, even if } \\
\text { separated transport } \\
\text { authorities have acquired an } \\
\text { increasing role in the largest } \\
\text { urban areas. } \\
\end{array}$ & $\begin{array}{l}\text { Medium/high } \\
\text { Vertically integrated public } \\
\text { transport operators } \\
\text { commonly assume (at least } \\
\text { partially) both operative and } \\
\text { revenue risks. }\end{array}$ & $\begin{array}{l}\text { Low } \\
\text { Tenders are exploited in few } \\
\text { cases and mainly in sub-urban } \\
\text { districts. }\end{array}$ & $\begin{array}{l}\text { Low } \\
\text { De-integration is low and } \\
\text { the contribution of } \\
\text { external operators is } \\
\text { limited. }\end{array}$ \\
\hline Spain & $\begin{array}{l}\text { Low } \\
\text { The prevalence of large } \\
\text { municipally owned companies } \\
\text { brings about the overlapping of } \\
\text { competences }\end{array}$ & $\begin{array}{l}\text { High/medium } \\
\text { Public owned companies } \\
\text { hold important tactical and } \\
\text { strategic decisions, even if } \\
\text { separated transport } \\
\text { authorities acquired an } \\
\text { increasing role in the largest } \\
\text { urban areas. } \\
\end{array}$ & \begin{tabular}{l}
\multicolumn{2}{c}{ High } \\
Vertically integrated public \\
transport operators \\
commonly assume (at least \\
partially) both operative and \\
revenue risks.
\end{tabular} & $\begin{array}{l}\text { Low } \\
\text { Tenders are exploited in few } \\
\text { territorial contexts and in sub- } \\
\text { urban districts. } \\
\text { The development of transport } \\
\text { authorities can contribute to } \\
\text { open up the local market. }\end{array}$ & \begin{tabular}{llr}
\multicolumn{3}{c}{ Low } \\
De-integration & is limited \\
as well as & the \\
development & & of \\
competition. & &
\end{tabular} \\
\hline Sweden & $\begin{array}{l}\text { High } \\
\text { The separation of roles is well } \\
\text { established since PTAs play the } \\
\text { regulatory role, while operators } \\
\text { provide services. }\end{array}$ & $\begin{array}{l}\text { Low } \\
\text { Little or nothing is left to } \\
\text { operators since they mainly } \\
\text { carry out the plans and } \\
\text { schedules prepared by the } \\
\text { PTA. }\end{array}$ & $\begin{array}{l}\text { Medium/Low } \\
\text { Net-cost experiences seem } \\
\text { to have come into } \\
\text { difficulties and the large } \\
\text { majority of contracts has } \\
\text { become gross-cost. }\end{array}$ & \begin{tabular}{ll}
\multicolumn{2}{c}{ High } \\
Generalized use & of \\
competitive tendering & to \\
entrust services. &
\end{tabular} & $\begin{array}{l}\text { Low/Medium } \\
\text { Separation is well } \\
\text { established, but only at the } \\
\text { lower levels of the } \\
\text { production chain. }\end{array}$ \\
\hline
\end{tabular}

Source: national study reports (Annex 1). 
Continuous differences come out in the ten countries included in the comparison, within an overall structure where the liberalization paradigm evolved rather slowly, without showing a linear and incremental trend.

The most outstanding experience is the GB-outside London model, where, at the end of the 80s and during the 90s, both de-integration (separation of roles and delegation of responsibilities) and on-track competition dramatically developed. But even in this case, as already discussed, in the last decades there has been an increasing attempt to influence and steer the outcome originated from market initiatives. A step back to a "less liberalized" market structure seems the ongoing trend, that needs however to be monitored on a longer time horizon to be fully assessed and confirmed.

The French case is consistent with a "medium" degree of liberalization. The delegation of service provision to external and independent operators is, in fact, largely predominant, in a model (network-tendering) where operators are given some service design freedom and, simultaneously, commercial risk. On the other hand, the last dimension of liberalization - i.e. contestability - is partially weakened by the characteristics of the tendering process: high discretion of the selection mechanism, large scales of tendered basins, low transparency, increasing risk attribution, so that the competitive pressure is declining and anticompetitive behaviours emerge (Amaral et al., 2009; Nash, Wolanski, 2010). The same forces, together with a quite consolidated nationalistic approach, favored the prevalence of large mainly public (State) owned market operators.

The Scandinavian (London) approach guarantees a clear-cut separation of roles and a higher degree of contestability. The selection process is transparent and competition is based on small size tendering process, more standardized selection criteria, and short term-gross cost contracts. However, de-integration is limited to the operational level, so that external providers are granted low margins of discretion, while PTAs keep a strong professional expertise to influence and control the whole process. In London, TfL also keeps operative capacities, directly managing the Underground and Croydon Tramlink.

The remaining case studies testify a minimal development of liberalization. Direct award to locally public owned companies is the prevailing organizational form in the main urban areas (Vienna, Bruxelles, Rome, Milan, Madrid, Barcelona, Warsaw, Munich, Berlin), while the involvement of third parties, completely independent from the competent authorities, is confined to small and complementary parts of LPT networks (Rome, Warsaw, Frankfurt).

As a whole, the main insights emerging from our investigation show relevant connections with the methodological contents of the first part of the study.

Firstly, the analysis confirms that the true separation of roles between internal and external actors represents a key and critical facet of the existing regulatory framework. Separation, to be considered a pre-requisite for liberalization (Fig. 4, above), is, in fact, well established only in few national contexts (GB, France 
and Sweden), whereas in other situations overlaps and informal influences still play a crucial role. Almost all the countries developed instruments to enhance the splitting of roles along the strategic-tactical-operational chain, above all through the development of contractual relations (contractualisation) and of specialized planning and regulatory authority. Nevertheless, these initiatives can be intended only as useful (and perhaps necessary) but non sufficient steps to develop a more clear separation between internal and external regulation. The real delegating and incentivizing power of contracts, in fact, is strongly undermined in those situations where the competent authority also influences (formally or informally) management decisions of the operator through its ownership relationships; or when it is used to take over financial deficit incurred by the self-owned company. In these circumstances, frequently encountered in the "ambiguous model" described above, no transparent market transactions and risk sharing are developed, so that speaking about separation and external regulation seems highly misleading. Even the role of (more or less) independent transport authorities is frequently misinterpreted, especially when intended as tools "to separate the purchasing from the provision of transport" (Brandt, Shulten, 2007 p. 39). Transport authorities need to be primarily seen as new management tools within the public administration, aimed to play the regulatory role in a more effective way, independently from the adopted organizational model. Certainly, they can help to keep skills and accumulated expertise within the public sphere and create more competent public procurer of local public transport, but they cannot ensure separation and de-integration if the contractual relation is mainly with "external operators" owned by the same public administration that controls the transport authority itself (as in Rome, Frankfurt, Innsbruck, Munich or Warsaw).

Secondly, excluding the GB-outside London case, a trade off between separation and the openness of the delegation comes out. The involvement of truly independent market operators into the service provisions has been mainly accompanied by a limited assumption/attribution of service design responsibilities and commercial risks by/to the operator itself (Scandinavian and London model, sub-contracting in the Flemish region, small scale tenders in Rome, Munich and Warsaw). On the contrary, where companies are still characterized by financial and political linkages with competent authorities, they commonly share higher decisional responsibilities (even influencing strategic decisions) and commercial risks (large networks in Italy, Poland, Germany, Austria and Spain). The interpretation of this outcome can be twofold. On the one hand, from the public viewpoint, the regulatory authorities seem to realise that the management of complex and open delegations can be problematic when only relying on market relationships (tendering, negotiations, civil law contracts). Therefore, they keep other levers to influence the market outcome (ownership, informal relationships, hierarchy, budget control, managers' appointing rules, etc.). In this perspective, true market outsourcing is mostly 
exploited when the principal-agent-relationship takes place at the bottom of the service provision process, and when informational and transaction costs are likely to be lower. On the other hand, from the operators' perspective, external providers seem to be reluctant to assume wider discretion and (accordingly) risks on services whose results are largely out of their control, above all when small scale networks are awarded. The prevalence of gross cost contracts (often coupled with quality incentives) in the case studies where the separation of roles is more developed (London ${ }^{75}$, Sweden, tendered non commercial services in Germany, several cases of sub-contracting) seem to give strength to this interpretative view.

Thirdly, the degree of contestability is geographically circumscribed and restricted as far as the scope of functions concerned. On the one hand, in most countries the largest share of LPT is still based on non competitive licenses or awards, and in nearly all these cases it is acknowledged that the municipal ownership of operators is a key barrier to start tendering (Osculati, Zatti, 2008; Loser, 2009; Augustin, Walter, 2010). Even where competition has been partially implemented (as in the $20 \%$ of the Italian bus networks) the too local approach to regulation, frequently influenced by the strict existing relationship between the buyer/regulator and the incumbent provider, has undermined the credibility of auctions, bringing about a rather conservative stance to most forms of competitive pressures (Osculati, Zatti, 2008; Bianco, Sestito, 2010). On the other hand, the supposed influence of the service design and risk allocation on the degree of contestability (see $\S 2.3$ above) is confirmed by the analysis. Higher level of competitive pressure is in fact found in those cases (Sweden, London, subcontracting experiences) where delegated functions are simpler and contractual design fairly complete; while the attribution of higher service design discretion (outline contracts, big network contracts, etc.) and of higher levels of risk (net cost contract) can operate as an entry barrier for the operators (French case). The latter effect is accentuated when opaque ownership relationships still exist between the regulator and the bidder, since the latter can likely rely on softer budget constraints. The higher competitive pressure also causes a relevant concentration of market providers (Sweden, GB and France), since smaller companies are frequently taken over by the larger ones. Concentration can act both as an efficiency enhancing opportunity, when it facilitates the exploitation of scale economies and stimulates a more managerial approach to service

\footnotetext{
${ }^{75}$ Pond (2006 p. 8), referring to the London experience, observes that: "The initial contracts were net cost....A report by the London Assembly says of this arrangement: The system was deeply flawed. This was due largely to operators adding premium to cover the risk of loosing revenue due to circumstances outside their control, such as long-term road works. Another disadvantage was that operators' revenues were affected by any changes to the bus network made by London Transport. Because the bus network constantly changes to match passenger demand patterns, a lot of effort was required to adjust contracts to take account of the effect on operator revenues".
} 
provision; but even as an obstacle, when it limits contestability and makes collusive behaviors easier. Therefore, it seems necessary the dimension of the market being sufficiently large (European?) and effective watchdog activities being carried out.

Finally, the idea that public bodies must retain a high standard of competence in a liberalized environment, if we exclude an almost fully deregulated system, is widely supported by the study. In fact, where some degree of liberalization has been developed in an unambiguous and consistent way, i.e. bringing about deintegration and competition at a certain level of the production chain, the need of transparent and well structured regulatory devices (specialized authorities, contractual arrangements, quality benchmarking, competition control, etc.), aimed at carrying out the activities of monitoring and evaluating the outcome, clearly followed ${ }^{76}$. This insight is strengthened by the fact that the prevalence of small scale gross cost contracts in outsourcing experiences further implies that greater responsibility and hence competence in planning, marketing and development of services are to be kept by public bodies (Longva, Osland, 2010).

\subsection{Towards a more private-ownership structure: to what extent?}

The investigation of the ownership structure (Tab. 5) shows a mixed outcome as well, without a clear-cut or dominant trend. In fact, private ownership in LPT is increasing, but the effect on the overall ownership structures is limited and incomplete.

\footnotetext{
${ }^{76}$ This example well denotes this outcome (Herman et al., 2007 p. 22-23): "One consequence of the shift to tendering regime is that efforts to control outcome have greatly increased. London Buses is an excellent example. The authority measures the performance of each route against minimum standards and benchmarks. Evidence stems on the one hand from the companies' own records on operated mileages. On the other hand the authority itself has created a sophisticated control system. Teams of approximately 120 part-time staff are sent out to selected observation points to record buses and their arrival and departure times with electronic devices... The data is then computed, validated and the results matched against the scheduled timetable. ...In addition London Buses also conducts passenger surveys to assess the quality of the different companies. A sample of passengers is interviewed each quarter covering a wide range of bus service features based on journey they have just made. Performance data is made available for individual routes and for all routes in a particular London borough.
} 
Table 5. Private-ownership in the selected case studies

\begin{tabular}{|c|c|c|c|c|}
\hline Austria & Belgium & France & GB-London & $\begin{array}{l}\text { GB-Outside } \\
\text { London }\end{array}$ \\
\hline \begin{tabular}{l}
\multicolumn{1}{c}{ Low } \\
Predominantly municipally \\
owned companies. \\
Large recourse to \\
corporatization. \\
Limited increase of private \\
operators on the interurban \\
network or like sub- \\
contractors.
\end{tabular} & $\begin{array}{l}\text { Low } \\
\text { Predominantly regionally } \\
\text { owned companies. } \\
\text { No corporatization. } \\
\text { The market share of small } \\
\text { private operators is limited to } \\
\text { the sub-contracted part of the } \\
\text { bus services (Wallonia and } \\
\text { Flanders) }\end{array}$ & $\begin{array}{l}\text { Medium } \\
\text { The most part of the French } \\
\text { Transport system is sill } \\
\text { managed by public or mixed } \\
\text { enterprises (state ownership). }\end{array}$ & $\begin{array}{l}\text { High } \\
\text { The local bus network is } \\
\text { almost completely served by } \\
\text { private operators. } \\
\text { TfL keeps direct managerial } \\
\text { and operative capacities } \\
\text { (Underground, Croydon } \\
\text { tramlink, some bus routes) so } \\
\text { that benchmarking is easy } \\
\text { and in-sourcing is still } \\
\text { possible. }\end{array}$ & \begin{tabular}{l}
\multicolumn{1}{c}{ Very high } \\
Market operators and even \\
bidders for social services are \\
big private companies.
\end{tabular} \\
\hline Germany & Italy & Poland & Spain & Sweden \\
\hline \begin{tabular}{l}
\multicolumn{1}{c}{ Low-Medium } \\
Predominantly municipally \\
owned companies. \\
Large recourse to \\
corporatization. \\
Limited increase of private \\
operators on interurban bus \\
networks and in regional \\
railway services.
\end{tabular} & \begin{tabular}{l}
\multicolumn{1}{c}{ Low } \\
Predominantly municipally \\
owned companies. \\
Large recourse to \\
corporatization. \\
The role of private operators \\
is marginal and generally \\
restrained to complementary \\
and rural routes or to \\
minority sharing together \\
with local incumbents in \\
urban areas.
\end{tabular} & \begin{tabular}{l}
\multicolumn{1}{c}{ Low } \\
Predominantly municipally \\
owned companies. \\
Increasing recourse to \\
corporatization. \\
The role of private operators \\
is marginal and generally \\
restrained to rural areas or to \\
complementary routes in \\
large urban areas. \\
Despite plans conceived at \\
the beginning of the $90 \mathrm{~s}$, few \\
companies have been truly \\
privatized.
\end{tabular} & $\begin{array}{l}\text { Low } \\
\text { Predominantly municipally } \\
\text { owned companies. } \\
\text { Increasing recourse to } \\
\text { corporatization. } \\
\text { The role of private operators } \\
\text { is marginal and generally } \\
\text { restrained to rural areas or to } \\
\text { complementary routes in } \\
\text { large urban areas. }\end{array}$ & $\begin{array}{l}\quad \text { Very high } \\
\text { Local public transport } \\
\text { services are almost } \\
\text { completely served by private } \\
\text { operators. }\end{array}$ \\
\hline
\end{tabular}

Source: national study reports (Annex 1)

Actually, in 6 countries (Austria, Belgium, Germany, Italy, Poland, Spain) privately owned operators mainly play a complementary role, serving additional services or inter urban routes, or acting as sub-contractors of large incumbent companies (Flanders, Wallonia, Vienna). In the few cases they have penetrated large urban markets, private entities have not taken action directly (winning tendering procedures for service management) but through the (until now slight and partial) privatization of municipal public transport companies or through the participation to PPP for large infrastructure construction and management.

Although privatization slowly evolved in these cases, a systematic shift in the legal form of public-service companies widely occurred. While previously part of the public administration and later autonomous public companies (special enterprises or agency), locally owned monopolies have been increasingly converted into private-law companies (join-stock companies or limited liability companies), with the partial exception of Poland where some municipalities have kept services in semi-independent agencies (budget enterprises). Shifting the supply of a service to separated publicly owned legal entities, under the same commercial law as private firms, is becoming a specific organizational form in LPT. This trend needs to be carefully investigated, given that knowledge on corporate governance within the public sector is less developed (Thomasson, 2010), and that existing contributions often put in light potential pitfalls and trade-offs in terms of transaction costs, public control and accountability (Osculati, Zatti, 2005; Obermann, 2007; Thomasson, 2010).

In Sweden and Great Britain privatization has been explicitly coupled with liberalization, becoming an instrument to ensure effective separation and 
guarantee higher production efficiency and cost savings. Accordingly, nearly all the market operators in bus services are now private companies, with a relevant role of major international operators, while public bodies still retain wider tasks (including direct management, as for the London Underground) in truck-based modes. Nevertheless, liberalization and de-integration do not necessarily depend on privatization. In the French case, in fact, large national public (RATP) or mixed operators (Keolis and Veolia Transdev) act as external providers with respect to the local competent authorities; a similar scheme can be found in the German or Italian regional railway sector, where the main suppliers are national state owned operators. In these cases, the key issue to guarantee effective liberalization is not the separation of roles, but, increasingly, the market openness (contestability), since the capacity of other, even foreign, operators to threat existing incumbents can be seriously hindered.

Finally, the horizontal analysis shows how private operators' involvement takes place at very different stages of the decisional chain. Private entities, in fact, are simply suppliers of specific functions (cleaning, ticketing, advertising, etc.), more and more outsourced to gain flexibility and cost-savings; can be subcontractors of large monopolistic operators (Flemish model); are route or small network providers regulated by strong sectoral agencies (Scandinavian model); can be large network providers (in the French model); can be service initiators in commercially oriented approaches (GB-outside London); can be, in some more recent experiences, partners in long terms PPP developed to finance and manage large infrastructures for track-based modes (Milan, Florence, Parla, Barcelona). The resulting idea is that the relationship between privatization and liberalization is more complex than frequently supposed, and in most cases the real contribution of private operators to the market outcome and structure is highly overstated.

\section{Concluding remarks}

In the last three decades, European LPT governance and market organization have been going through relevant changes, but none unambiguous and paradigmatic model emerged. Striking differences persist between national contexts, both in the structure as well as in the regulation of the supply; while, at the same time, sectoral trends have been in many cases characterized by tortuous courses: stop and goes, legislative wavering, adjustments in the contractual forms, changes in the allocation of risks, re-regulations of markets, recover of influence of the state sector, etc.

The adoption of the EU Regulation on land transport in 2007 is not deemed to change dramatically this overall picture. The regulation, in fact, grants ample freedom of choice to Member States and sub-national governments to choose their organizational models, so that the ultimate impact of the ongoing 
normative framework is (and will be) to a large extent left to national implementation measures. It is therefore quite misleading to talk about a real Europeanization process in LPT, while subsidiarity and local experimentation seem to be the leading characteristics.

Within this general approach, the horizontal analysis shows that the general interest is well acknowledged in European local public transport, above all in urban services: public authorities, left free to decide, retain relevant powers to influence the market structures and outcomes, so that regulation, although through heterogeneous approaches, is widely accepted as a necessary pillar of the market organization. In six countries the self-owned company model, commonly based on direct award and strong formal and informal links between the competent authority and the operator, is, in fact, the prevailing organizational model. At the same time, where a more competitive approach has been developed (Sweden and London, and, to a lesser extent, France), the involvement of external operators through competitive tendering takes place at the low stages of the decisional chain; so that the scope of the delegation is fairly narrow. In these cases private operators acquire a larger role in the ownerships structures; while where the delegation is more open (higher service design freedom and higher risk assumption), public ownership prevails. Only in the GB-outside London model privatization and liberalization have moved forward more extensively, but results are highly conflicting and steps back not negligible.

The emerging idea is that LPT services are complex services, for which outsourcing is not easy and transaction costs can be relevant, thus preventing or at least discouraging ampler step towards external regulation. At the same time, as risks taken by the operators depend even (and sometimes mostly) on the actions under the responsibility of local public authorities - parking policies, traffic management, land use planning, coordination with other modes - the attitude of the market operators to be regulated by commercial and highly risky contracts seems limited. It is not surprising that, all in all, liberalization and privatization prudently evolved and that outsourcing (often through the increasing recourse to sub-contracting) mainly progressed when simpler and small scale tasks are involved.

In this framework, characterized by the widespread recognition of the public role, a major theoretical and analytical interest should be directed to the ability of the principal-competent authority to play its role in an effective and sound manner, while often to much attention is focused on the characteristics of the agent-operator (public or private, big or small, foreign or national, etc.).

Regulated competition, in particular, is increasingly seen has an "attractive and innovative" opportunity to perform the regulatory role, and has brought about encouraging results in several case studies. However it is necessary the adoption of more "market based" approaches being founded on a set of consistent and conscious choices and actions: adequate definition of available resources, 
development of regulatory capacity to manage contracts, true separation of roles, clear service design responsibility and risk sharing, adequate management of main tangible and intangible assets, real market contestability, etc. Liberalization and competition, at least as they have been until now experienced in the European LPT sector, are far from being "open delegation" and the idea that external regulation and competitive tendering relieve the public authority of the need of expertise is clearly mistaken and brings about doubtful results.

At the same time, competent authorities are free to decide, because of high agency and transaction costs, to keep a wholly public provision regime. In this case, no true outsourcing process takes place and different mechanisms of control should be implemented: transparency, accountability, budget unity, tighter administrative direction, more direct political responsiveness, etc.

From this point of view, some rather well characterized models come out from the report, either involving external regulation (Sweden, London, France, "indirect tendering" experiences), or leaving the production chain within the public administration (Belgium). Yet, several countries still show too ambiguous attitudes towards service organization and developed hybrid market forms. In particular, a quite extended "favour" towards corporatization, intended as an intermediate solution with respect to the divide internal/external regulation, ensues. However, results are not convincing and it is to be hoped that the full application of the EU regulation on land transports can bring about a more defined outcome. 


\section{Annex I}

National case study reports 


\begin{tabular}{|c|}
\hline AUSTRIA \\
\hline $\begin{array}{l}\text { General findings } \\
\text { - Services are mainly organized along single routes where passengers are picked up and dropped off at defined } \\
\text { stops. } \\
\text { - System based on exclusive authorizations to be renewed (normally after eight years). } \\
\text { - Profitable routes are under the initiative of transport entrepreneurs, but must not endanger the commercial } \\
\text { profitability of existing transport companies. The opinions as to whether a right of exclusion can be derived from } \\
\text { this are disputed. } \\
\text { - Non profitable routes must be tendered. The difference between profitable and unprofitable routes is however } \\
\text { ambiguous and several forms of financial contributions (special tariffs, ticket price compensations, infrastructure } \\
\text { grants, etc.) as well as cross subsidies granted to LPT operators are commonly considered fare revenues. } \\
\text { Accordingly, competitive tendering for non profitable routes is limited to new routes or restricted areas of the } \\
\text { network. } \\
\text { - Exclusive direct authorization to municipally owned companies is the prevailing organizational form in the } \\
\text { main urban areas (Vienna, Linz, Graz, Klagenfurt, and Bergenz). In Innsbruck and Salzburg the regional } \\
\text { government shares the ownership of the company too. } \\
\text { - Vertically integrated municipal companies plan, build and operate the urban network through formal or } \\
\text { informal agreements. } \\
\text { - Outside urban poles interurban service provision is dominated (up to } 85 \% \text { ) by a Company owned by the } \\
\text { Federal State. Private companies hold the remaining share. } \\
\text { - Short distance Rail passenger transport is dominated ( } 98 \% \text { by a State owned public company under private law } \\
\text { (Postbus AG). }\end{array}$ \\
\hline 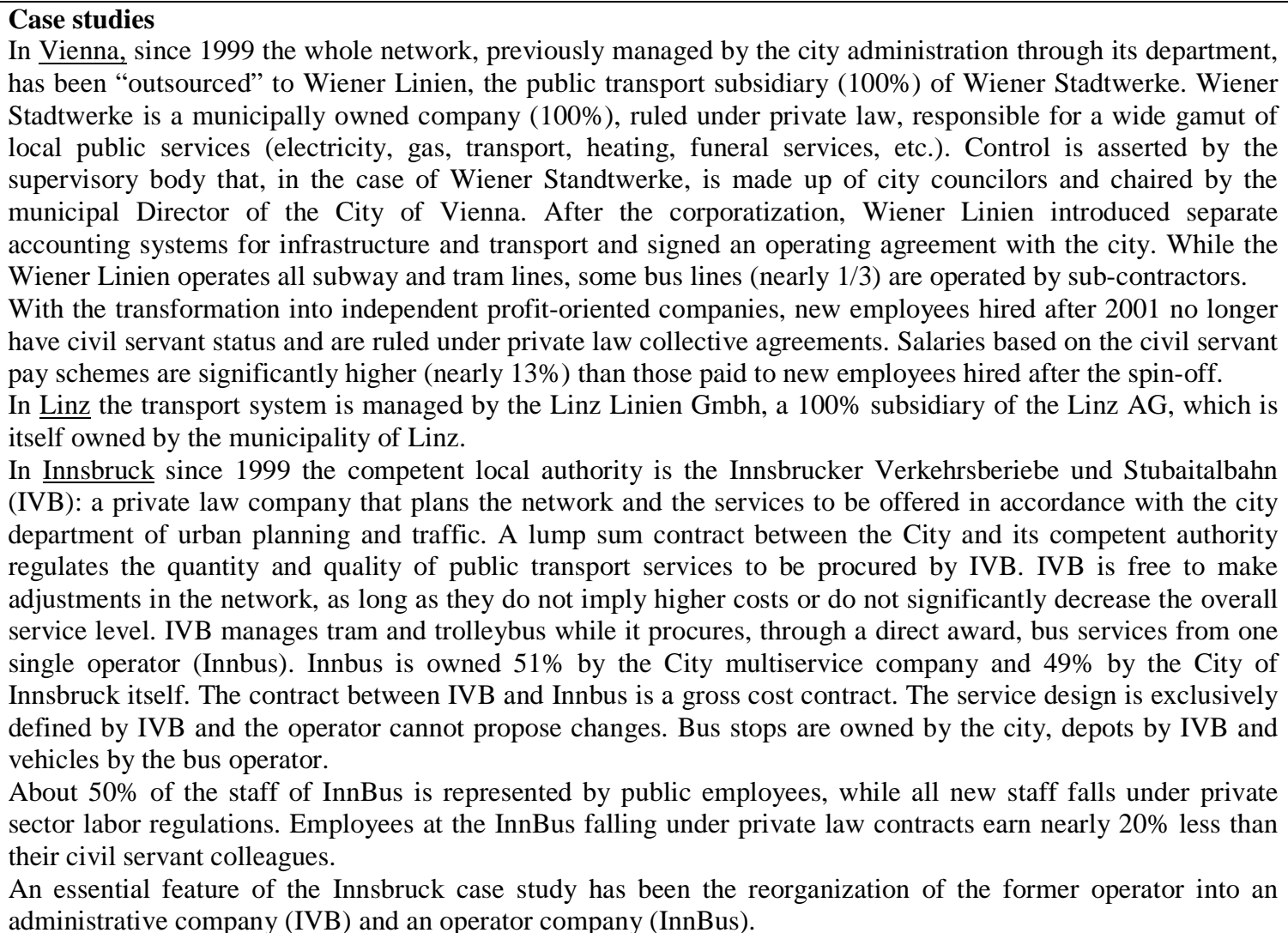 \\
\hline $\begin{array}{l}\text { Separation } \\
\text { Separation of roles is low, since most of large networks are still managed by companies owned by the competent } \\
\text { authority. } \\
\text { In the future, the role of regional transport associations as subjects responsible to put contracts out to tender for } \\
\text { particular routes or bundles of routes could increase the real split between planning and operations. However, } \\
\text { tendering by steering committees of the Transport Associations can be problematic, as local territorial } \\
\text { governments are usually part of both the steering committee and the transport companies. }\end{array}$ \\
\hline
\end{tabular}




\section{Contestability}

Companies already running services (incumbents) are favoured over any other new applicant and are to a large extent shielded against contestability.

Tendering is developed on additional and complementary routes, as well as in some regional rail services. After 2005 some Land authorities started competitive tendering with formal publication.

Very low mobility of providers and lack of involvement of multinational companies.

\section{Delegation of service-design responsibilities}

Vertically integrated public transport operators have wide responsibilities as far as service planning and operation and infrastructure building are concerned. Public owned companies hold important tactical and strategic decisions.

\section{Delegation of risk}

Commonly operating and commercial risks lay within the municipal company. In Innsbruck the compensation to the operator is paid in terms of gross cost contract.

\section{Privatization}

Since the end of the ' 80 s municipal operators have been increasingly transformed into separate legal entities under private law (corporatization). Being companies under private law, they no longer show up in the budget of the municipalities and can directly hire their employees. After the spinning off, several publicly owned corporations have employees under different forms: there are public appointees, on the one hand, and there are employees under private law on the other. Accordingly there are two different forms of agreements: a civil servant pay scheme and a sector private collective agreement. The largest companies, as Wiener Linien and Postbus AG, also have their company level collective agreements.

Medium and small private companies operate mainly on the interurban network or as sub-contractors (e.g.

Vienna), accounting for a small share of the market.

Source: Hermann (2006); Brandt, Shulten (2007); van de Velde et al. (2008) ; Loser (2010). 


\section{General findings}

\section{BELGIUM}

- Exclusive direct award of each regional network by the three regional governments to their owned operators still under public law and budget ("organizations of public interest"). "La choix à etè fait de garder les operateurs dans le giron public ».

- Increasing recourse to sub-contracting to private operators in Wallonia (30\%, without tendering) and in the Flemish region $(45 \%$, mainly through tendering).

- Private operators are small entities (family companies) generally operating under gross cost contracts and with no freedom in services design. Some large international companies are entering the sub-contracting market.

- Public operators act as planner, provider, purchaser and regulator of the service: "de simple exploitant, rôle désiré à l'origine par les pouvoirs public, l'opérateur devinent un manager de la mobilité a l'échelle de la Région".

\section{Case studies}

In the Brussels region a net cost contract regulates the relation between the bus operator (STIB) and the Brussels-Capital region. STIB is the only party allowed to operate public transport in the Region. STIB is a limited company of public law, with its own legal personality, totally owned by the regional government. The Board of Directors as well as the managing director are appointed by the regional government.

The contract between the Ministry of Brussels Capital region and the operator STIB allows a large initiative to the latter. STIB is actually responsible for the tactical level and also has certain responsibilities on the strategic one: advising the region for mobility policy, involvement in updating transport plans, investments aiming at encouraging inter-modality; STIB also has a high level of autonomy to determine its own tariffs, within limits set by the Region. The contract is flexible: it can be changed by the addition of clauses, in particular taking account of a potential revision of the political guidelines established by the Region. This can have consequences for the resources allocated to STIB.

Rail infrastructures (tram and metro), vehicles and other installations are all owned by the STIB. The distinction of roles between the operator and the competent authority is vague: e.g. daily operations of rail infrastructure are carried out by STIB, while maintenance is paid for by the Region and carried out by STIB; investments in new infrastructures and rolling stock are commonly paid by the Region but owned by the operator; STIB has also allocated a small yearly investment budget to act rapidly for specific works; in case of substantial extra-costs due to external causes, the Region and STIB negotiate about compensatory measures.

Several monitoring provisions are in place. These include evaluation mechanisms regarding customer satisfaction (measured through questionnaires) as well as a benchmark comparing STIB to other operators.

In the Flemish region the bus operator (De Lijn) is linked to the regional government by a net cost contract.

De Lijn sub-contracts nearly $45 \%$ of bus services to private operators (around 90 contractors) through competitive tendering and this share is deemed to arrive to $50 \%$. The system currently adopted by De Lijn is a model of indirect tendering, where the public in house operator acts as provider, planner, purchaser and regulator.

It is the Flemish government that determines the percentage of the total exploitation that has to be entrusted to a third party. The idea to keep a part of the supply in-house is due to the wish to maintain production expertise and bargaining power in front of possible oligopolies or the necessity to in-source parts of the network.

In 2001 the Flemish parliament approved a decree on basic mobility (Decret Basismobiliteit), guaranteeing a minimum offer of organized transport to the user/consumer. This minimum offer implies a minimum service frequency and a maximum distance to and waiting time at bus stops. This decree implied a regulation increase in the bus and tram sectors in the Flemish region and brought about an increase of the supply by nearly $70 \%$ between 2000 and 2008. De Lijn has to respect the minimum standards established by the decree.

In the Walloon region the whole bus network is directly awarded to a public law operator (Groupe TEC) whose shareholders are the region, provinces and municipalities. TEC has five subsidiaries responsible for the exploitation of services within single specific areas. Municipalities in those geographic areas can own at most $49 \%$ of the share of the subsidiary. The remaining share belongs to the mother company.

TEC is linked to the regional governments by a net cost contract. However, the government also influences the bus companies through its ownership and the representatives elected in the Board of Directors. Local governments have also representatives in the Board of directors.

TEC entrusts the coverage of about $1 / 3$ of its bus network to private operators without competitive tendering.

TEC has even acquired smaller private bus companies in recent years.

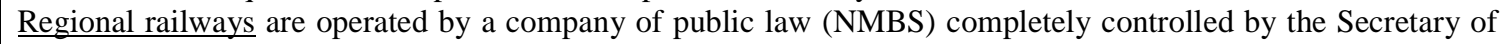
State responsible for state enterprises. Another public law company (Infrabel) manages the infrastructures and regulates the access to the network. 


\section{Separation}

The separation of roles is weak, and operators keep relevant tactical and even strategic responsibilities. The whole decisional chain is shared among regional governments and public companies strictly controlled by them. Management contracts are concluded between the regional governments and their owned transport providers. These contracts mostly include specific aims related to the quantity and quality of the service and include commitments from the authority as to the subsidization budget available to the operator. Since operators are strictly linked to regional governments, the scheme is not based upon true contractual relationships and all principal-agent interactions are to a large extent demanded to the hierarchical-unilateral control rather than to the "market discipline". According to Goethals (2010 p. 9): "Les gouvernements sont les organes de tutelle et contractant du contrat de gestion, mais aussi les actionnaires dominants... Ce double rôle du gouvernement lui donne la possibilité, en tant que propriétaire de l'entreprise, d'intervenir dans les décisions et la gestion de l'operateur... Les autorités publiques conservent cependant le pouvoir de contrôler les activitès de l'entreprise... Si cette intervention dans les affaires de l'exploitant venait à se manifester réellement, le contrat de gestion perdrait a nouveau son caractère incitatif $»$.

The true separation happens at the operational level in cases when sub-contracting to private operators is carried out (Wallonia and Flanders).

\section{Contestability}

No attempts to develop direct competitive tendering. Contracts with the three public operators are directly awarded.

High degree of market concentration.

Recourse to sub-contracting to private suppliers for the operational level; only in the Flemish region contracts are entrusted through tendering. There is not competition between public operators and private sub-contractors. Competition is only established in the Walloon and Flemish regions between private operators that want to win contracts with the public companies.

Large international private operators (Connex, Eurobus, and Veolia) have started to buy small local companies and to act as sub-contractors of public operators in the Walloon and Flemish regions.

Clauses have been adopted in tender contracts which define the working conditions in public companies and in outsourced tendered services have to be the same.

\section{Delegation of service-design responsibilities}

Public operators have strong responsibilities and margin of manoeuvring in the services definition.

Private sub-contractors operate single routes or small-scale networks with no freedom in service design. Public operators establish routes, timetables, stops, typology of vehicles, tariffs and tickets. Private sub-contractors receive a fixed payment in terms of $€ / \mathrm{km}$ supplied.

\section{Delegation of risk}

Public operators are submitted to the production cost risk and revenue risk, with various financial incentives.

Private sub-contractors assume only operating cost risks.

\section{Privatization}

STIB, DE LIJN and TEC are para-regional companies under public law. The capital is owned by the region (and for a minor part by the municipalities). They are classified under local government (c.1313) under the ESA95 classification. Their budgets are still included in the budget of the regional authorities.

The market share of private companies is limited to the outsourced part of services provided by the public enterprises.

Labour conditions between the private and public sector are similar and wage dumping is limited by the action of the Unions.

Source: Verhoest, Sys (2006); van de Velde et al. (2008); Goethals (2010). 


\begin{tabular}{|c|}
\hline FRANCE \\
\hline $\begin{array}{l}\text { General findings } \\
\text { - Direct award to a public company (RATP) in Paris and Ile de France } \\
\text { - Outside the Paris region, competent authorities (municipalities, agglomerations, and syndicates) are entitled to } \\
\text { produce transport services themselves or to delegate this prerogative to external private or mixed companies. In } \\
\text { the case of external delegation, since } 1993 \text { the French law (loi Sapin) requires the recourse to competitive } \\
\text { awarding procedures. The legislation applicable to public transport allows for negotiation within the tendering } \\
\text { procedure so that public authorities have a large degree of freedom to choose their providers. } \\
\text { - Out of Paris, the management of services is generally delegated to external operators through tendering } \\
\text { (negotiated) procedures ( } 90 \% \text { of cases). } \\
\text { - Self production (regie o regie autonomes) by the public administration mainly in small cities (with the } \\
\text { exception of Marseille). } \\
\text { - External providers are few large groups. There are three major operators: one is public (state owned), one is } \\
\text { private, one is mixed (with public preponderance). The private operator and the public one are going to merge in } \\
\text { early } 2011 . \\
\text { - Costs and risk sharing are very differently allocated case by case, but the proportion of local operators } \\
\text { regulated by net cost contracts is increasing. } \\
\text { - Commonly the whole network is entrusted to a single operator (network contracts) with the possibility for him } \\
\text { to sub-contract part of the services. } \\
\text { - High rate of renewal of incumbent operators after tendering (>80\%) } \\
\text { - Operators commonly keep some responsibilities in service definition, above all during the negotiation stage }\end{array}$ \\
\hline 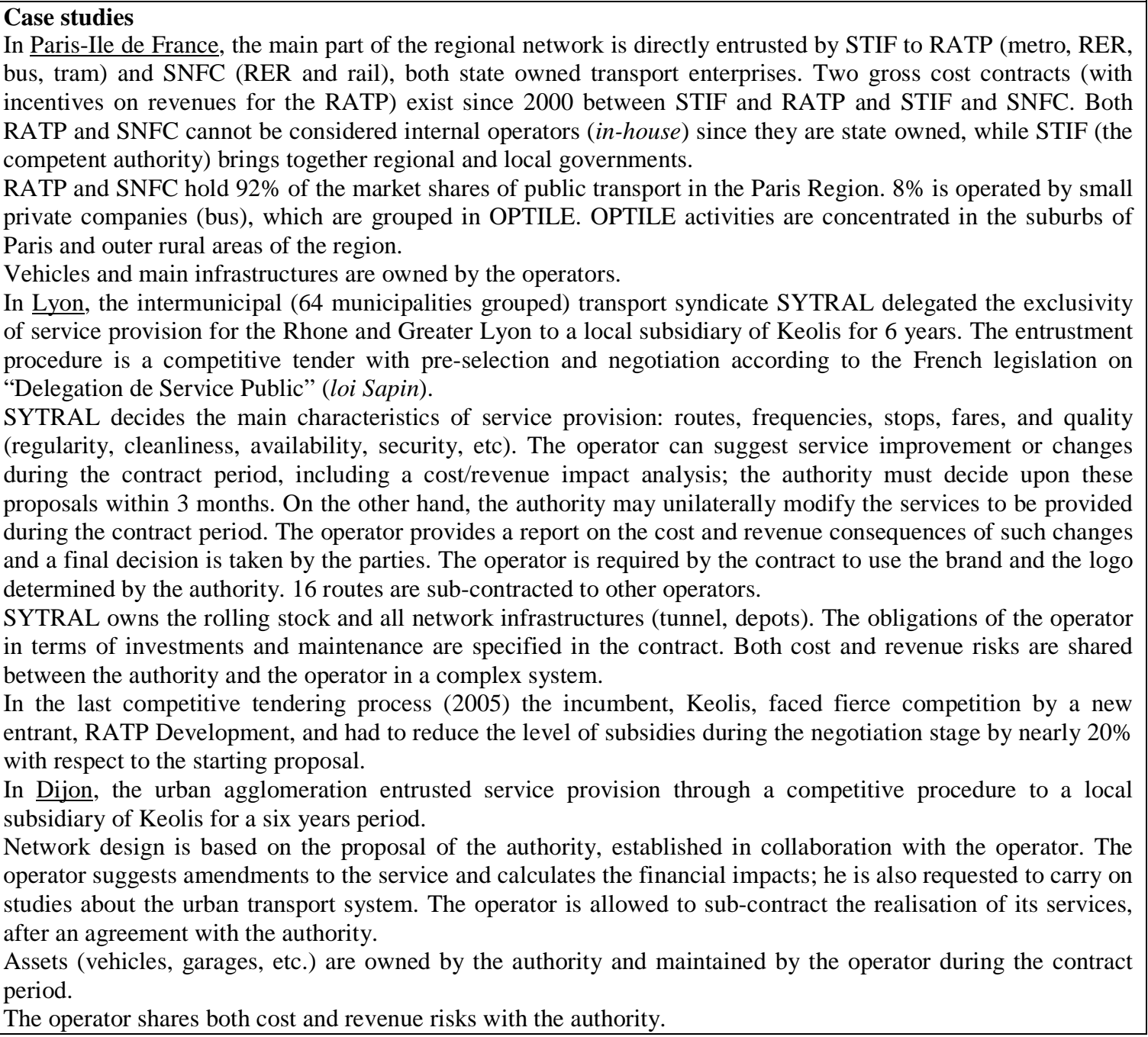 \\
\hline
\end{tabular}




\section{Separation}

Clear cut separation of roles.

In the case of in-house production the local government manages the supply directly (regie) or through a special enterprise (regie autonome or Etablissement public) strictly linked to the public administration, so controlling the process from downstream to upstream.

In case of delegation (predominant), services are entrusted to a third body almost completely independent from the competent authority. Providers are in fact private operators or even public operators, but owned by a public subject different from the buyer (SNFC or Caisse des Depots).

Even in Paris separation is to a large extent guaranteed, since the competent authority, STIF, is expression of regional and local governments, while RATP and SNFC are owned by the national government.

\section{Contestability}

- Competitive tendering to external operators is the main procedure implemented to entrust services.

- Local authorities have a high discretional power in the selection process, given that the assessment of the most suitable bidder is complex and does not only rely on quantitative methods. Local authorities are not bound to select the final set of bidders or the winner according to the objective and precisely predefined criteria. Their selection criteria can therefore include subjective elements such as reputation or confidence. However they must be able to justify their choice and their decision is controlled by the regional level. As a whole, this procedure combines competitive bidding and negotiation contents.

- Few large groups dominate the market of tendered services.

- Decreasing number of bidders and high rate of renewal of incumbent operators after tendering $(>80 \%)$. The

French model provides fewer incentives for bidders to enter into the game, but takes care of scale economies.

- Commonly, assets, infrastructures and even vehicles are provided by the public authority

- The competent authority is in charge of taking over the personnel in case of transfer of operator, including all associated rights and obligations.

- Collusive behaviour among the three leading operators has been revealed by the Antitrust Authority in 2005

\section{Delegation of service-design responsibilities}

In the delegation model operators have margins to propose and submit service design adaptations, above all during the negotiation phase. Negotiation, even during the execution of the contract, is advocated since the service is complex and sizeable (network contracts), so that ex post adaptations are expected.

\section{Delegation of risk}

In the in-house case there is no risk transfer between the competent authority and external operators.

In other cases (delegation), a dramatic change in the type of contracts chosen by the local authorities occurred since the $1970 \mathrm{~s}$, with an increasing preference for high powered incentives contracts instead of cost-plus contracts. In $2007,54 \%$ of the French networks had Net cost contracts. This trend reveals a clear determination of the local authorities to make the operators bear a growing proportion of risks.

\section{Privatization}

RATP is a special enterprise under public law (Etablissement public) owned by the State.

About $70 \%$ of local networks are covered by three large companies: Keolis (27\%), Transdev (17\%), and Veolia Transport (27\%). AGIR (association of private operators, 12\%) and smaller independent companies (19\%) hold the remaining share.

Keolis is a mixed company, mainly shared by SNFC (56\%), the national state-owned railway company.

Transdev is a subsidiary of Caisse des Dépôts et Consignations and operates in several European and extra European countries. Caisse des Dépôts and its subsidiaries constitute a state-owned group at the service of the public interest and of the country's economic development.

Veolia is a private company.

In 2011 Veolia and Transdev are going to merge in Veolia Transdev, jointly owned by Veolia Environment and Caisse des Dépôts.

As a matter of fact, a large part of the French Transport system is sill managed by public or mixed enterprises; more recent evolutions show a stronger influence of the state sector at the expense of the purely private sector. Source: van de Velde et al. (2008); Amaral et al (2009); Zadra-Veil (2010). 


\begin{tabular}{|c|}
\hline GERMANY \\
\hline $\begin{array}{l}\text { General findings } \\
\text { - Exclusive direct authorization to municipally owned companies is the prevailing organizational form in the } \\
\text { main urban areas. Direct awarding through renewal of the incumbent's license covers nearly } 91,5 \% \text { of the } \\
\text { market share; tendering is observed for } \approx 6 \% \text { of the market; commercial services for just } 2,5 \% \text { of the market. } \\
\text { - Vertically integrated municipal companies plan, build and operate the urban network through formal or } \\
\text { informal agreements. Service planning tasks and risk sharing are opaque. } \\
\text { - Profitable routes (including fare reductions and special fares covered by public authorities) are under the } \\
\text { initiative of transport entrepreneurs that can get an exclusive right for the provision. Since } 203 \text {, services covered } \\
\text { by market initiative have been increasing, but the number of cases remains tiny compared to the total market } \\
\text { volume of public transport by buses. Most of them are services in rural and suburban areas. } \\
\text { - Competitive tendering is obligatory for non profitable routes since } 1996 \text {. Its role remains limited because } \\
\text { services provided by municipal companies are defined to be profitable using revenues from cross-subsidisation } \\
\text { and capital grants. The legal distinction between commercial and non-commercial services is ambiguous and at } \\
\text { the centre of much debate. } \\
\text { - Tendering used mainly on additional and complementary routes and in regional rail services. Tendering also } \\
\text { implemented in some concentrated territorial context (Frankfurt and State of Hesse, Suburbs of Munich and } \\
\text { Hamburg). } \\
\text { - Sub contracting is developing in some urban areas where the existing in-house operator is progressively } \\
\text { withdrawing its operative role. } \\
\text { - Small private companies operate mainly on the interurban network and account for a small share of the market } \\
\text { (<20\%; < } 10 \% \text { excluding short distance trains). } \\
\text { - Notwithstanding the formal liberalization process of the middle nineties, the market shares hardly changed. } \\
\text { - Municipal operators have been increasingly transformed into separate legal entities under private law } \\
\text { (corporatization). } \\
\text { - Municipal companies developed several internal organizational changes (subcontracting, outsourcing of } \\
\text { selected tasks, etc.) to cope with budget constraints and short cuts in public funding. }\end{array}$ \\
\hline 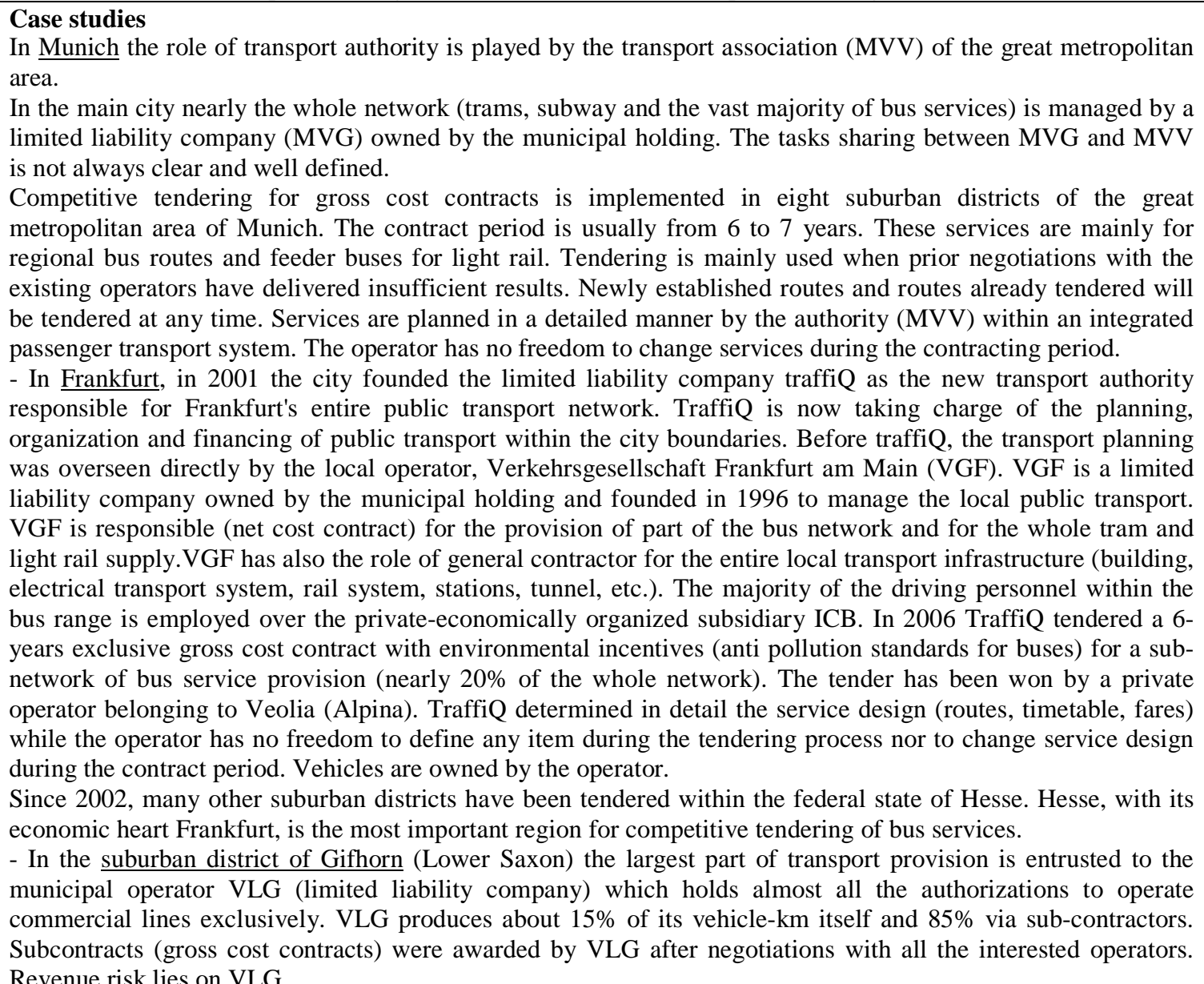 \\
\hline
\end{tabular}


VLG has key tactical and even strategic responsibilities in the service design and planning.

- In Berlin the whole local public transport system (metro, trams, buses and river boats) is managed by a public institution Berliner Verkehrsbetriebe (BVG) completely owned by the municipality. According to his Statute, BVG can operate only within the State of Berlin and in line with the contents of the establishing Statute. BVG is linked to the local authority by a net cost contract. BVG is responsible for the tactical level and even for some of the strategic decisions. BVG is a member of the Transport Association Verkehrsverbund Berlin-Brandenburg (VBB), which coordinates and integrates services and fares within the two Landers. BVG exploits subsidiaries and sub-contracting under private law to reduce costs.

- In Potsdam the whole local transport network is covered by a limited liability company $100 \%$ owned by the municipal holding company. $47 \%$ of the operator's revenues comes from cross-subsidization from other urban services.

- In the Brandenburg Lander bus and tram services are provided by 35 operators: mainly represented by limited liability company owned by the local competent authority.

- In the short distance railway sector Landers are free to contract with DB (Deutsche Bundesbahn: state owned railways company) or to issue calls for tender. Some States implemented competitive tendering in the last 10 years to award service provision (about $20 \%$ of train kilometers). However, the majority of contracts is still awarded directly to DB through its subsidiaries DB-Regio.

The tendering for railway concessions is mainly based on large volume contracts with a duration of 10 or 12 years; the definition of services is very detailed and with an increasing rigidity of the institutions ordering services.

\section{Separation}

The separation of roles is low in urban services, since the major part of large networks is still managed by companies owned by the competent authority. Separation is more developed in regional rail service where the main operator is a state owned company and even private operators are increasing their presence.

In the future, the role of transport agencies (as in the case of Frankfurt) or of regional transport associations (as in Munich) as subjects responsible for tendering of particular routes or bundles of routes could increase the real split between planning and operations.

\section{Contestability}

- Companies already running services (incumbents) are favoured over any other new applicant in urban areas and are to a large extent shielded against contestability.

- Very little competitive tendering is observed in the bus sector. Tendering is developed on additional and complementary routes and in some specific territorial context. Mean contractual length is about six years.

- The potential future competition stimulated cost cutting initiatives since the mid-1990s.

- Where competitive tendering has been implemented in the bus sector the probability of operator change is quite high (nearly 60\%). Private companies gained ground with respect to incumbents. A decreasing competitive intensity is recognized.

- Municipal ownership is seen as a barrier to competition.

- The German authorities commonly do not provide any vehicles, infrastructure facilities or staff.

- About $20 \%$ of the supply is allocated following competitive tendering in short distance railway services. The most successful bidder have been DB-Regio (45\%) and the international companies Arriva and Connex.

- Very low mobility of providers and limited involvement of multinational companies. Few international players entered the German market, mainly due to legal uncertainty and the defensive approach adopted.

\section{Delegation of service-design responsibilities}

Vertically integrated public transport operators keep wide responsibilities as far as service planning and operation and infrastructure building. Public owned companies hold important tactical and strategic decisions.

Where tendering (and even sub-contracting) is implemented (as in Frankfurt, in the Munich suburbs or in the railway services) the competent authority keeps all the strategic and tactical levers (detailed contracting).

\section{Delegation of risk}

Vertically integrated public transport operators commonly assume (at least partially) both operative and revenue risks.

Where tendering is implemented, operators hold only operative costs. Net costs contracts play an ancillary role

\section{Privatization}

Privatizations in Germany took mainly place in the form of changes in the legal form of the companies.

Since the end of the ' 80 s municipal operators have been increasingly transformed into separate legal entities under private law (corporatization or formal privatization). Although the change of the legal forms was interpreted as a first step towards privatization, the owners of most communal transport companies are still local competent authorities.

The market share of public companies in short distance public transport (2005) is about $80 \%$, whereas private companies reach only $15 \%$ and mixed companies $5 \%$. The market shares concerning ownership relations hardly changed in public transport between 1991 and 2003. 
The main way to enter the German market for foreign operators is through the (until now slight) privatization trend of municipal public transport companies. Velia, Connex and Arriva, for example, have acquired shares in local transport companies. However, private majority is exceptional.

In the last ten years, new private competitors became increasingly successful in winning contracts in the regional train service provision in the last ten years. While they account for only $5 \%$ of the regional rail passenger market, the new competitors have more than doubled their market share in this period.

Source: Shulten (2006); van de Velde et al. (2008); IUA (2009); Augustin, Walter (2010); Bech (2010); Buhler, Pucher (2011). 


\section{GREAT BRITAIN-LONDON}

\section{General findings}

- Central planning, full outsourcing and privatizations are the three pillars of the London model.

- All service planning by Transport for London (TfL): the transport authority of the Greater London that also directly operates (through subsidiaries (the Underground, Croydon Tramlink (in-sourced in 2008) and London River services.

- Generalized use of competitive tendering to entrust bus services.

- Mainly route-by-route contracts. Routes are awarded every four to five years (with a possibility of a 2 years extension) and are operated on an exclusive basis.

- Progressive evolution from net to gross-cost contracts with quality incentives.

- Tender procedures highly standardized to reduce administrative costs and increase transparency

- Competition and privatization developed progressively: former monopolistic operator (London buses) completely privatized in 1994; by the end of 1995 half of the network had been tendered at least once, and by the beginning of 2001 all the bus miles were supplied through tendered contracts.

- Dockland Light Rail services (DLR) are entrusted for 7 years to a private operator through a competitive procedure including negotiations at the final stage of the procedure. The contract is a gross-cost contract with incentives. The transport authority defines the network of services and specifies minimum service frequencies and capacity requirements. Infrastructures and rolling stock are owned by the authority and leased to the operator.

- Metropolitan railways services are entrusted through tendering to external operators.

\section{Separation}

The separation of roles is well established since TfL plays the regulatory role, while operators provide services.

TfL has kept a strong professional expertise to control the whole process and to monitor external operators. The regulator has a strong discretionary power and can even disqualify bidders if their market share is too high, while incumbent bidders are explicitly preferred. The authority measures the performance of each route against minimum standards and benchmarks. Teams of part-time workers are sent out to selected observation points to record buses and their arrival. TfL also conducts passenger surveys to assess the quality of the different companies and their surveys.

\section{Contestability}

- Competitive tendering is the standard awarding mechanism

- Tenders are mainly route or small bundle tenders based of minimum costs.

- The selection process is transparent and highly standardized.

- Data on existing services and providers are disclosed to the market.

- TfL controls and maintains the stops and bus stations. Depots and vehicles are owned by operators and this circumstance can restrict contestability.

- Nearly $40 \%$ of contracts have changed suppliers with tendering procedures

- $80 \%$ of bus routes run by seven major private companies

- Multinational transport companies have increased their presence

- TfL has kept managerial and operative capacities so that in-sourcing is possible in case of unsuccessful entrustment to external providers (as occurred for the Croydon Tramlink)

\section{Delegation of service-design responsibilities}

TfL determines the transport networks and frequencies, timetables and the common appearance of buses (constructive contract). It is also responsible for monitoring the providers performances.

Contracts are under constant review and there is no limit on the number of changes which can be undertaken during a contract period.

Delegation of risk

The large majority of contracts is gross-cost. Operators only bear the production risk, while the authority carries the revenue risk. TfL exploits operators mainly as an arm's length to deliver a good service.

\section{Privatization}

The local bus network is almost completely served by private operators.

Private operators manage, after tendering, also short distance railways and light rail services (DLR).

TfL operates through a subsidiary the underground. Investment and maintenance of London Underground structures are run under a public and private partnership by two private consortia.

TfL directly manages the Croydon Tramlink. Croydon Tramlink was originally entrusted to a private operator through a 99 year concession (built, operate and maintain). In 2008 TfL took over the private company and insourced Tramlink services.

TfL still manages some bus routes through its subsidiaries, keeping the opportunity to gather data on many different aspects of the service (time, schedule, comfort, etc) and to benchmark private operators with their public competitor.

Source: Pond (2006), Butcher (2008), van de Velde et al. (2008), Amaral et al. (2009). 


\begin{tabular}{|c|}
\hline GREAT BRITAIN-OUTSIDE LONDON \\
\hline $\begin{array}{l}\text { General findings } \\
\text { - Benchmarking case for deregulation, commonly coupled with privatization. } \\
\text { - Free market entry for bus services on commercial routes: bus companies get permanent non-exclusive licences } \\
\text { and are free to choose the routes they want to operate. Regulation has been reduced to mere technical and safety } \\
\text { matter (soft regulation). } \\
\text { - Privatization has been seen as a necessary step to be coupled with deregulation to achieve a more committed } \\
\text { management and better access to private capital. } \\
\text { - The bus market is dominated by few private operators. } \\
\text { - Social-non commercial routes tendered to private operators. Currently around } 20 \% \text { of the total local bus service } \\
\text { mileage outside London is supported by local authorities. } \\
\text { - The role of local transport authorities (PTAs) has gained momentum with the } 2000 \text { and } 2007 \text { Transport Acts. } \\
\text { Quality partnerships and quality contracts with private operators represent the main instruments to re-regulate } \\
\text { the market provision. }\end{array}$ \\
\hline $\begin{array}{l}\text { Case studies } \\
\text { In Leeds the local PTA and the city Council formulated an agreement with two private companies operating on } \\
\text { few specific urban corridors. The starting principle has been that the objectives of the bus operator and those of } \\
\text { local authorities can be met more effectively if they share a common set of goals and initiatives. PTA and City } \\
\text { Council provided capital to construct guide ways on three radial routes; the bus operators agreed to provide new } \\
\text { buses equipped with guide wheels to allow buses to use the new guide ways. This is a voluntary agreement under } \\
\text { free market conditions and without exclusivity. } \\
\text { Quality partnerships have been developed in more than } 30 \text { other towns and cities. The } 1999 \text { bus consultation } \\
\text { paper reported that they had increased patronage by typically } 10 \text { to } 20 \% \text { and by up to } 40 \% \text { where there were bus } \\
\text { segregation and substantial improvements in roadside infrastructure. } \\
\text { In Manchester the local public transport authority is responsible for supporting non-commercial routes across } \\
\text { Greater Manchester, a Metropolitan County made up of ten constituent district authorities. The Authority } \\
\text { complements the market initiated services buying additional services through tenders. Tendered services have no } \\
\text { exclusivity. } \\
\text { Contracts are typically } 5 \text { years net cost contracts. Contracts may be left for specific journeys, a specific route or a } \\
\text { package of routes. Bus stations are provided by the authority. Operators provide buses and depots. The operators } \\
\text { can surrender the contract, after a pre defined notice period, if they no longer wish to provide the service under } \\
\text { the contract terms. }\end{array}$ \\
\hline $\begin{array}{l}\text { Separation } \\
\text { The separation between regulatory authorities and operators is full and no ambiguity emerges. }\end{array}$ \\
\hline $\begin{array}{l}\text { Contestability } \\
\text { Free market entry formally guarantees a high level of market contestability. } \\
\text { Deregulated bus market dominated by } 5 \text { big operators, often running monopolies within a single area. In January } \\
2010 \text { the competition Commission launched a market inquiry into local bus services to control the presence of } \\
\text { collusive behaviors. }\end{array}$ \\
\hline $\begin{array}{l}\text { Delegation of service-design responsibilities } \\
\text { Market operators are usually completely free to decide service design and characteristics. } \\
\text { Through quality partnership and, even more, quality contract, PTAs re-acquired some margins to influence the } \\
\text { market outcome. } \\
\text { Where non-commercial services are entrusted, detailed contracts are usually implemented. }\end{array}$ \\
\hline $\begin{array}{l}\text { Delegation of risk } \\
\text { On commercial routes operators assume all the risks. } \\
\text { On tendered routes, public authorities commonly share the revenue risk with operators. }\end{array}$ \\
\hline $\begin{array}{l}\text { Privatization } \\
\text { Market operators and even bidders for social services are mainly big private companies. }\end{array}$ \\
\hline
\end{tabular}

Source: Pond (2006), van de Velde et al. (2008), Amaral et al (2009); Butcher (2010a and b). 


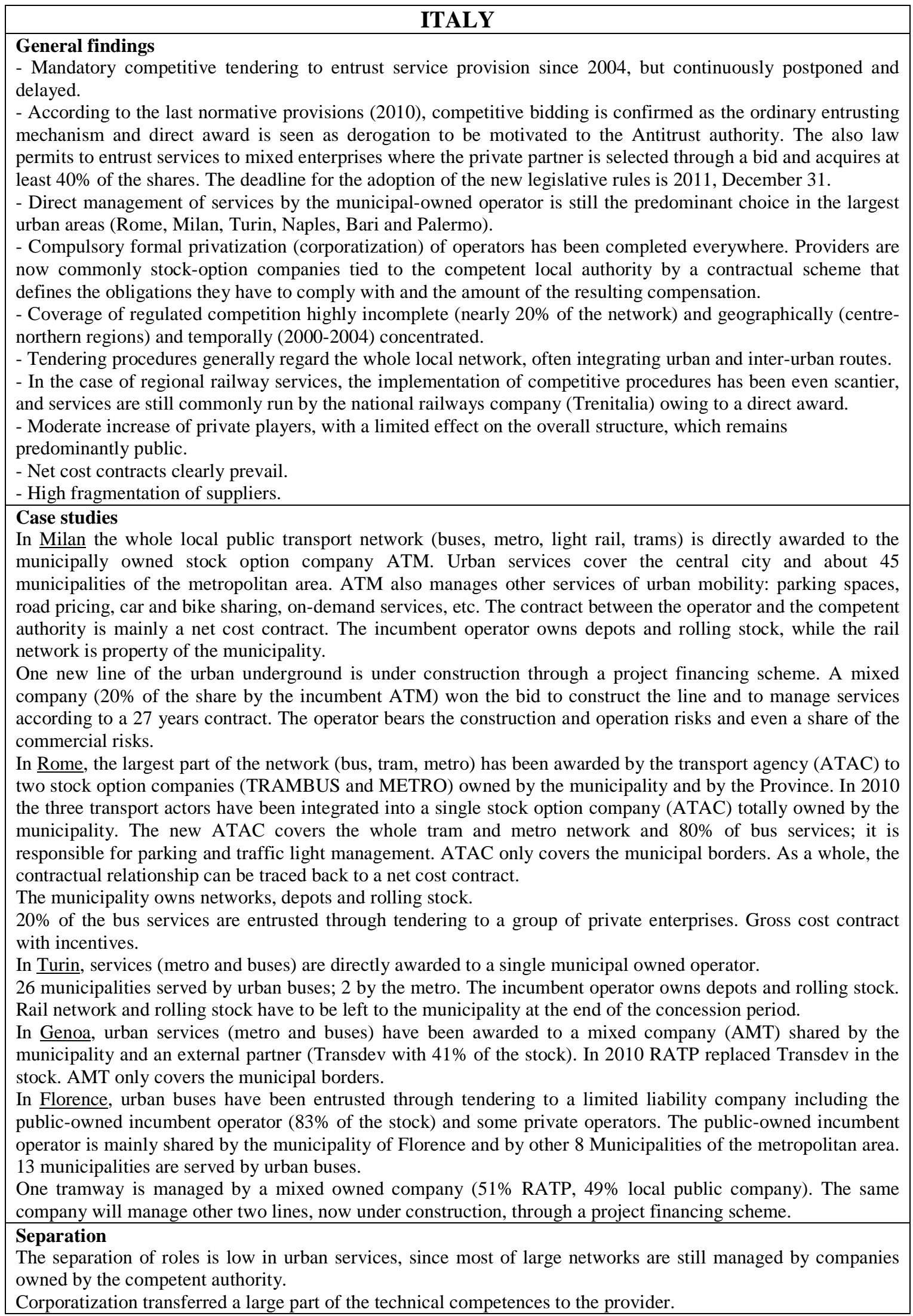


Even when tenders have been carried out, the incumbent operators have won the bid in the majority of cases. According to the Antitrust Authority, until now the persistence of ownership relations has discouraged local governments from selecting providers different from the incumbent and, furthermore, has strongly influenced the managerial autonomy of the companies.

\section{Contestability}

- Since 2004, competitive bidding is formally the ordinary way of entrusting services.

- Municipally owned incumbents keep a preferential position, above all in the main urban areas.

- Tendering developed in $20 \%$ of the network.

- Low number of bidders ( $<3$ in nearly $70 \%$ of cases).

- The incumbent operator has been generally entrusted to provide services, alone or with other partners $(80 \%$ of cases).

- The selecting mechanisms do not favour competition (large networks, multidimensional tenders, incomplete separation of asset ownership and management from service provision, social clauses for the existing staff).

- The local approach to regulation, influenced by the strict existing relationship between the buyer/regulator and the incumbent provider, undermined the credibility of auctions.

- The declining public support for urban transport can favour incumbent operators which can rely on softer budget constraints in tendering procedures.

- Collusive devices among existing operators, to divide up the territory, have been revealed and sanctioned by the Antitrust Authority.

- Territorial mobility nearly absent and modest incidence of foreign players.

Delegation of service-design responsibilities

Vertically integrated public transport operators have wide responsibilities as far as service planning and operation and infrastructure building are concerned. Public owned companies hold important tactical and strategic decision.

Where tendering is implemented for additional or complementary routes (as in the $20 \%$ of the urban bus network in Rome) the competent authority keeps all the strategic and tactical levers (detailed contracting).

Delegation of risk

Vertically integrated public transport operators commonly assume (at least partially) both operative and revenue risks (net cost contract are prevalent).

Privatization

Formal privatization of operators is compulsory. Formal privatization should have represented an intermediate step of the reform but has until been one of the main outcomes.

Local operators frequently exchange shares among themselves with the almost exclusive aim of coordinating and concerting their activities in the context of controlled competition.

The role of private operators is marginal and generally restrained to minority sharing together with the local incumbent.

Source: Osculati, Zatti (2008). 


\begin{tabular}{|c|}
\hline POLAND \\
\hline $\begin{array}{l}\text { General findings } \\
\text { - Communes are free to decide the organizational model of municipal public transport. } \\
\text { - Variety of different organizational models at the local level: self production, direct award to commercial } \\
\text { companies under municipalities' control, competitive tendering to external entities. } \\
\text { - Market initiatives in small villages and rural areas. } \\
\text { - In urban transport the majority of operations (nearly } 90 \% \text { ) is carried out by self production (so called budgetary } \\
\text { establishment) or (increasingly) corporatized municipal operators. } \\
\text { - Public transport authorities have been created within some public administration (Warsaw, Gdansk, Cracow, } \\
\text { and Poznan) to play the regulatory role. } \\
\text { - Competitive tendering to private operators is exploited to serve some complementary routes in large urban } \\
\text { areas, mainly where transport authorities have been established, or in some small villages. }\end{array}$ \\
\hline 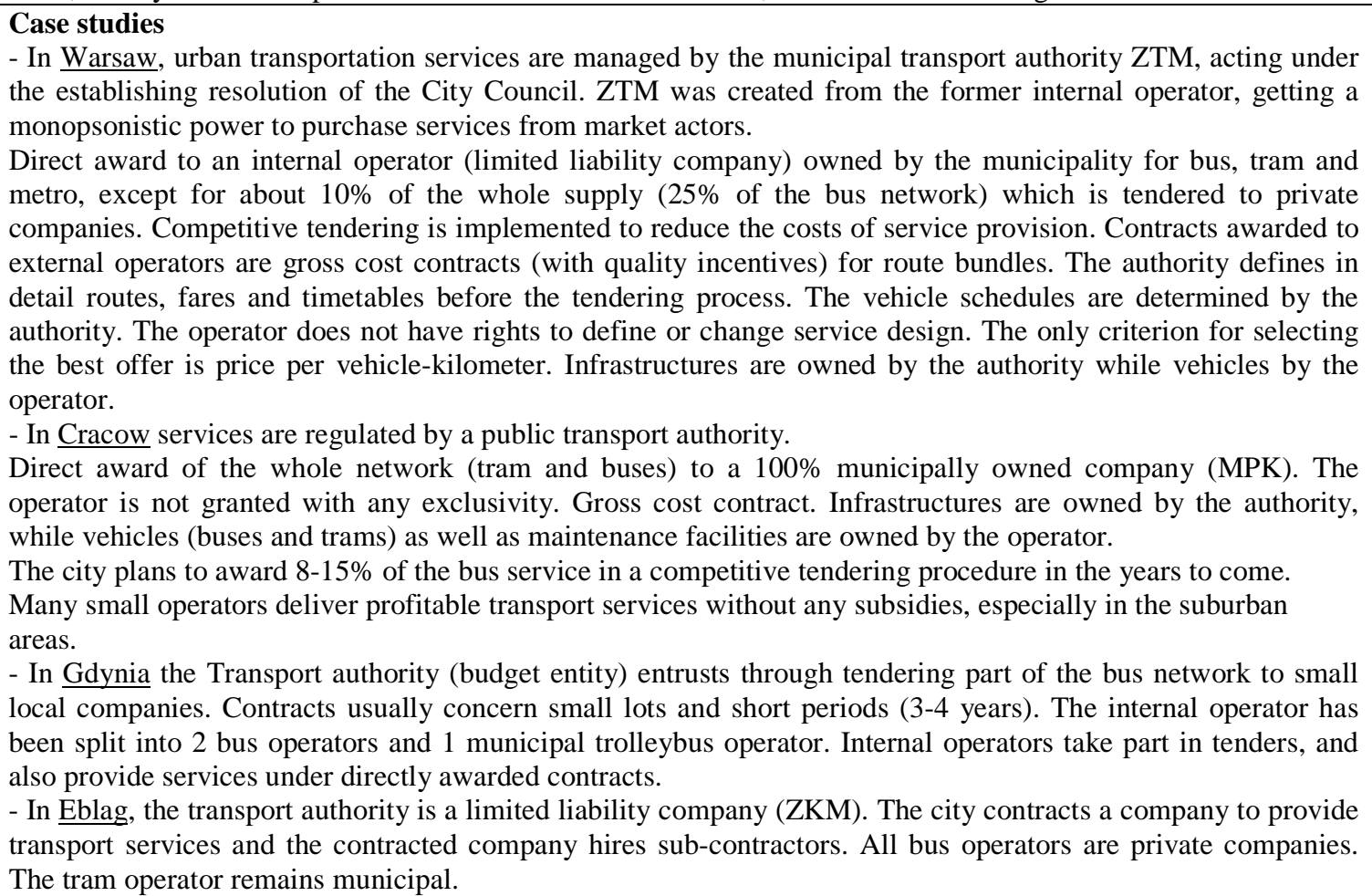 \\
\hline $\begin{array}{l}\text { Separation } \\
\text { The separation of roles is still weak since the largest share of the services is provided directly (budget } \\
\text { companies) or by a locally owned commercial company. The development of transport authorities originating } \\
\text { from the incumbent operator can help to increase the separation of roles and keep expertise within the public } \\
\text { administration. } \\
\text { Budgetary establishments (or companies) are public entities without legal personality formed by a municipal } \\
\text { council resolution. When forming a budgetary establishment, the municipal council adopts the budgetary } \\
\text { establishment's articles of association setting out inter alia the objects and purpose for which the establishment } \\
\text { is created. With budgetary companies there is not a true separation of roles and the basis for the performance of } \\
\text { the public utility task is the internal act specifying the scope and the duration of the public service obligation. } \\
\text { Managers of the budgetary establishment act on behalf of the commune and on its account. } \\
\text { Commercial companies under the municipal control acquire a legal personality, but the separation of roles is still } \\
\text { weak. The purpose of the public company should in fact be described in a detailed manner in the resolution } \\
\text { establishing the company itself, without a true contractual relationship between the parties. } \\
\text { Both with budgetary establishment and municipal owned companies the function of organizer and operators are } \\
\text { not fully separated. } \\
\text { When transport services are entrusted to an external entrepreneur (being an individual or a legal person), the } \\
\text { relationship is based on a civil law contract according to general principles and the separation is more clear. }\end{array}$ \\
\hline
\end{tabular}




\section{Contestability}

Tenders are exploited in few cases and in sub-urban districts.

The role of municipal companies is still prevailing and hinders the opportunity to have really open tenders.

Incumbent operators commonly own bus stations and this represents a serious barrier for the future development of competition.

The development of transport authorities is increasing the opportunity to open up local market.

Delegation of service-design responsibilities

Public owned companies hold important tactical and strategic decision, even if separated transport authorities acquired an increasing role in the largest urban areas.

When cooperating with private operators (routes or bundle routes tendering), local authorities delegate few competences and responsibilities.

Delegation of risk

Vertically integrated public transport operators commonly assume (at least partially) both operative and revenue risks.

In the relationships with external private operators gross cost contracts are commonly exploited.

Privatization

Formal privatization of operators is acquiring an increasing role.

The role of private operators is marginal and generally restrained to rural areas or to complementary routes in large urban areas.

Despite plans conceived at the beginning of the 90 s, few companies have been truly privatized.

There are many barriers obstructing privatization.

Source: Kubisa (2006); Wolanski (2008); van de Velde et al. (2008); Jaspers (2009). 


\section{SPAIN}

\section{General findings}

- The local competent authority is free to decide whether to directly deliver the service, either thorough its own administrative units or through a separate legal person (local public enterprise, joint stock option company, limited liability company) or to delegate the provision of services to a private party through a contract, regulated under the Public contract act.

- Direct management by municipally owned enterprises prevails.

- The development of Transport syndicates, grouping local competent authorities and upper levels of government (province, regions and even national government), is spreading to play the regulatory role.

- Contractualisation between Transport authorities and transport operators is gaining ground.

- Operators have frequently responsibilities in service design.

- Operational and revenue risks borne by the operator, but with soft budget constraints.

- Construction and operation of a new tramway line in Parla and Barcelona assigned to a mainly private operator (PPP).

- Interurban transport frequently entrusted to private operators.

\section{Case studies}

In Madrid the bus network is directly awarded to EMT: a public company owned by the city of Madrid and in charge of the service provision since 1947. EMT is linked to the Competent Authority (the transport syndicate CRTM) by a framework contract. EMT has been more recently transformed into a private law company. EMT also manages parking policies within the city of Madrid.

Metro services are directly managed by another public owned operator (Metro Madrid) run under private law and linked to the CRTM by a contract.

Interurban and peripheral services are mainly entrusted through exclusive service concessions to private operators (33 private companies). Entrusted routes are grouped into bundles so that each bundle can be selffinancing.

In Parla (Madrid region) the urban bus network is directly managed by a locally owned operator. Recently (2005), the authority (CRTM) selected through competition an operator to build, finance, operate and maintain a new tramway line over a period of 40 years (PPP). The contract is a net cost contract. Line design and fares levels were previously defined by the Municipality and CRTM.

In Barcelona the urban transport services (metro and buses) are directly entrusted to a commercial company (FCC-TMB) owned by the Metropolitan transport authority (EMT). TMB is linked to the larger Metropolitan transport authority (ATM) by a framework contract that states the obligations of each part. Vehicles and other installations are owned by the operator. Routes and timetables are proposed by the operator and approved by ATM that is responsible for the integrate planning on the larger metropolitan area. Operational and revenue risks are borne by the operator.

The construction and operation of the two tramway lines have been assigned to consortia participated by the incumbent tram operator $(20 \%$ and $5 \%$ ) and by private operators (80\% and $95 \%)$. By using PPP, Barcelona acquired further private capital to enable the investment into new tramlines.

In Oviedo the management of urban public transport has been entrusted to a private operator for a period of 25 years. Gross cost contract with incentives. Routes are defined in the tender, but operator can propose alternatives in accordance with the transport master plan. The operator owns vehicles and other installations. At the end of the concession the assets are acquired by the concessionaire by their residual value.

\section{Separation}

The development of transport syndicates has improved the separation of roles. They are increasingly in charge of relevant strategic and tactical decisions while service provision is left to operators.

The presence of large municipally owned companies brings about competence overlapping.

When transport services are entrusted to an external entrepreneur (being an individual or a legal person) the separation of roles is highly increased.

\section{Contestability}

Tenders are exploited in few territorial contexts and in sub-urban districts.

The development of transport authorities is increasing the opportunity to open up local markets.

The role of municipally owned companies can hinder more contestable market structures.

Operators frequently own vehicles and installations and this circumstance can further hinder contestability.

\section{Delegation of service-design responsibilities}

Public owned companies hold important tactical and strategic decisions, even if separated transport authorities have acquired an increasing role in the largest urban areas.

Where network tendering has been implemented (Oviedo), the operator has been given some opportunity to influence service design. 


\section{Delegation of risk}

Vertically integrated public transport operators commonly assume (at least partially) both operative and revenue risks.

In the relationships with external private operators gross cost contracts are commonly exploited (case of Oviedo).

Privatization

Formal privatization of operators is acquiring an increasing role.

The role of private operators is marginal and generally restrained to rural areas or to complementary routes within urban networks.

In large urban areas, private entities have been mainly involved through their financial contribution to PPP initiatives (Parla and Barcelona).

Source: IAU (2008); van de Velde et al. (2008); Martin Urbano et al. (2010). 


\begin{tabular}{|c|}
\hline SWEDEN \\
\hline $\begin{array}{l}\text { General findings } \\
\text { - Local governments can freely choose the organizational model to deliver services and are ultimately } \\
\text { responsible for financing and execution. } \\
\text { - Public transport authorities (PTAs), set at the county or metropolitan level, have assumed an increasing role in } \\
\text { the strategic and tactical level. In several cases, transport authorities take the form of a private law company } \\
\text { owned by local and regional authorities. } \\
\text { - Since the second half of the } 80 \mathrm{~s} \text {, the service operation has been progressively contracted out by competitive } \\
\text { tendering. Tendering emerged as a solution to lower public spending. } \\
\text { - Competitive tendering is now the prevailing organizational form in LPT. Tendering is not limited to bus } \\
\text { services, but it also spread to most regional railway services and the Stockholm metro. } \\
\text { - Mainly route-by-route contracts, with limited discretion for operators. } \\
\text { - Mainly gross cost contracts. } \\
\text { - Mainly private operators. In several cases, publicly owned companies were privatized or taken over. } \\
\text { - Concentration processes have been growing with competition and smaller companies taken over by the larger } \\
\text { ones. }\end{array}$ \\
\hline 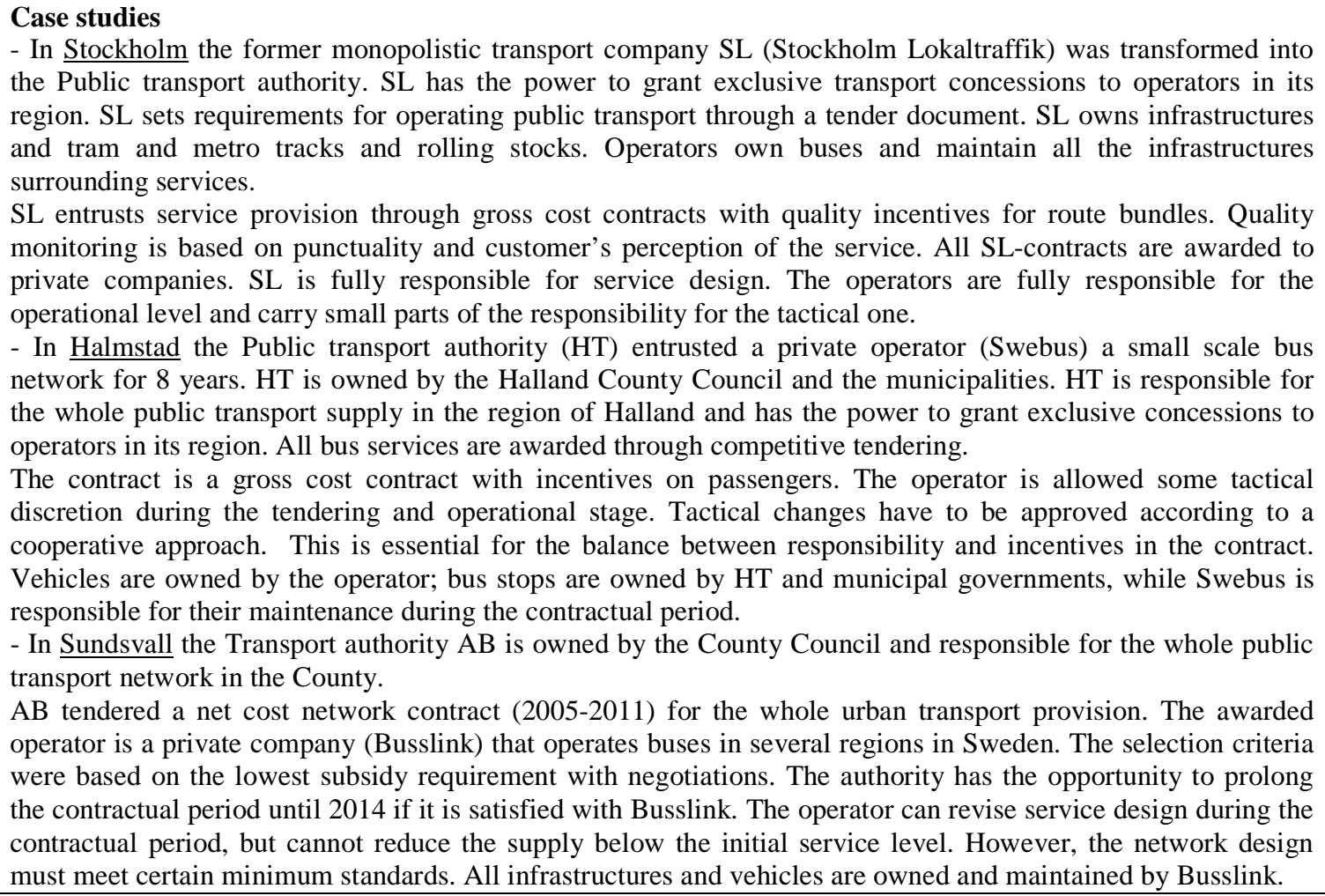 \\
\hline $\begin{array}{l}\text { Separation } \\
\text { The separation of roles is well established since PTAs play the regulatory role, while operators provide services. } \\
\text { The relationship between public administration and PTAs is more ambiguous: either contractual, political and } \\
\text { ownership relationships coexist. } \\
\text { PTAs have kept a strong professional expertise to control the whole process and monitor external operators. } \\
\text { The operators are manly private operators, so that independence by the regulator is guaranteed. }\end{array}$ \\
\hline $\begin{array}{l}\text { Contestability } \\
\text { - Competitive tendering is the standard awarding mechanism for urban transport services. } \\
\text { - Tenders are mainly route tenders based on minimum costs. } \\
\text { - PTAs own the main infrastructures and essential facilities. } \\
\text { - Multinational transport companies have increased their presence in the market. }\end{array}$ \\
\hline $\begin{array}{l}\text { Delegation of service-design responsibilities } \\
\text { PTAs determine the transport networks and frequencies, even timetables and the appearance of buses. They are } \\
\text { also responsible for monitoring the performances of providers. }\end{array}$ \\
\hline
\end{tabular}


Little or nothing is left to the operators decision since they mainly carry out the plans and schedules prepared by the PTAs.

Delegation of risk

The large majority of contracts is gross-cost. Net-cost experiences seem to have come into difficulties manly because the division of service planning responsibilities between operator and transport authorities leaves few opportunities to the former to influence the attractiveness of services.

Privatization

Local public transport services are mainly served by private operators.

PTAs are commonly limited liability companies owned by the local administration (counties and in some cases municipalities).

Source: Hamark, Tornqvist (2006); Johansson (2008); van de Velde et al. (2008); Bruijnes (2009). 


\section{References}

Amaral M. (2008), Public vs. private management of public utilities - The case of urban public transport in Europe, Research in Transportation Economics 22, pp. 8590 .

Amaral M., Saussier S., Yvrande-Billon A. (2009), Auction procedures and competition in public services: The case of urban public transport in France and London, Utility Policy 17, Issue 2, pp. 166-175.

Augustin K., Walter M. (2010), Operator changes through competitive tendering: Empirical evidence from German local public bus transport, Research in Transportation Economics 29, pp. 36-44.

Bauby P., Similie M.M. (2010), Public services in the European Union \& in the 27 Member States. Statistics, organisation and regulation, Study commissioned in the framework of the "Mapping of the Public Services" project managed by CEEP.

Beck A. (2010), Commercial public bus transport services in Germany: How a market in motion struggles with its regulatory framework, Research in Transportation Economics 29, pp. 183-194.

Bianco M., Sestito P. (2010), I servizi pubblici locali. Liberalizzazione, regolazione e sviluppo industriale, Il Mulino, Bologna.

Bird R., Slack E. (2004), Fiscal Aspects of Metropolitan Governance, IT Paper 0401, Toronto.

Bognetti G., Obermann G. (2008), Liberalization and privatization of public utilities: origins of the debate, current issues and challenges for the future, Annals of Public and Cooperative Economics 79: 3/4, pp. 461-485.

Brandt T., Schulten T. (2007), Report on the transformation of labour relations in public services, Privatization of public services and the impact on quality, employment and productivity (PIQUE), Project funded under the European Commission's $6^{\text {th }}$ Framework Programme, Deliverable 8, Dussendorf.

Brandt T., Schulten T. (2008), The impact of liberalisation and privatisation on labour relations, Privatization of public services and the impact on quality, employment and productivity (PIQUE), Project funded under the European Commission's $6^{\text {th }}$ Framework Programme, Policy paper 2, Dussendorf.

Bruijnes R. (2009), Continental drift: connecting Great Britain and Scandinavia, paper presented at the $11^{\text {th }}$ Conference on competition and ownership in land transport, Delft, The Netherlands September 20th to $25^{\text {th }}$.

Buehler R., Pucher J. (2011), Making public transport financially sustainable, Transport Policy, 18, pp. 126-138.

Butcher L. (2008), Transport in London. House of Commons Library, Research Paper 08/36.

Butcher L. (2010a), Buses: Quality Partnerships and Quality Contracts. House of Commons Library, SN/BT/624, July.

Butcher L. (2010b), Buses: deregulation in the 1980s. House of Commons Library, SN/BT/1534, July.

Butcher L. (2010c), Buses: funding and subsidies. House of Commons Library, SN/BT/1522, July. 
Colin Buchanan and Partners (2003a), Guides to contracts and contracting in public transport, Report for the EU Commission.

Colin Buchanan and Partners (2003b), Transferibility of best practice in transport policy delivery: Final Report, Report for the Scottish Government.

Doronzo R., Florio M. (2007), Privatisation, Unbundling, and Liberalisation of Network Industries: A Discussion of the Dominant Policy Paradigm in the EU, Paper presented at EPSU/ETUI-REHS/SALTSA Conference "An Alternative to the Market. The Social, Political and Economic Role of Public Services in Europe", Brussels.

ECMT-European Conference of Ministers of transport (2002), Implementing Sustainable Urban Travel Policies, Paris.

European Commission (1997), Isotope, Transport research, Fourth Framework Programme, Luxembourg.

European Commission (2000), Interpretative Communication of the Commission on concessions in Community Law, OJ C 121.

European Commission (2003), Green Paper on Services of General Interest, (COM(2003)270final).

European Commission (2004), Green Paper on Public-Private Partnerships and Community Law on Public Contracts and Concessions, (COM(2004)327final).

European Commission (2005), Public Service Compensation in Practice: Commission Package on State Aid for Services of General Economic Interest, Competition Policy Newsletter, n.3, pp. 34-37.

European Commission (2010), Guide to the application of the European Union rules on state aid, public procurement and the internal market to services of general economic interest, and in particular to social services of general interest, SEC(2010)1545final).

Falcone R., Castelfranchi C. (1999), Levels of Delegation and Levels of Help for Agents with Adjustable Autonomy, AAAI Technical Report SS-99-06.

Flecker et al. (2009), Privatization of public services and the impact on quality, employment and productivity (PIQUE). Summary report. Project funded under the European Commission's $6^{\text {th }}$ Framework Programme, Wien.

Goethals C. (2010), Les transports publics urbains en Belgique, Brussels.

Goldberg J. (2006), Draft EU regulation on public service requirements. Which consequences for local public transport?, Associations for European Transport and Contributors.

Grzelec K., Wolanski M., Wyszomirski O. (2009), Connecting competition and integration. A concept of new organizational framework for Polish local bus transport, paper presented at the $11^{\text {th }}$ conference on competition and ownership in land transport, Delft, The Netherlands September 20th to $25^{\text {th }}$.

Hamark J., Tornqvist C. (2006), Liberalisation, privatisation and regulation in the Swedish local public transport sector, Privatization of public services and the impact on quality, employment and productivity (PIQUE), Project funded under the European Commission's $6^{\text {th }}$ Framework Programme, Goteborg.

Hensher D.A., Stanley J. (2010), Contracting regimes for bus services: What have we learnt after 20 years?, Research in Transportation Economics 29, pp. 140-144. 
Hermann C. (2006), Liberalisation, privatisation and regulation in the Austrian local public transport sector, Privatization of public services and the impact on quality, employment and productivity (PIQUE), Project funded under the European Commission's $6^{\text {th }}$ Framework Programme, Vienna.

Hermann et al. (2007), Varieties and Variations of Public-Service Liberalisation and Privatisation in Europe, Project Privatization of public services and the impact on quality, employment and productivity (PIQUE), Project funded under the European Commission's $6^{\text {th }}$ Framework Programme, Wien.

Hibbs, J. (2009), Contracts and partnerships, Economic Affairs, Volume 29, Issue 3, September, pp. 77-80.

ISOTOPE (2003), Improved Structure and Organisation for Urban Transport Operations of Passengers in Europe, Project funded by the European Commission under the $4^{\text {th }}$ Framework Programme.

IUA-Institut d'Amenagement et d'Urbanisme (2008), La place des bus dans les transport collectifs de Madrid, Paris.

IUA-Institut d'Amenagement et d'Urbanisme (2009), La place des bus dans les transport collectifs de Berlin et du Brandenburg, Paris.

Jaspers (2009), State Aid Issues in Financing Urban Transport in Poland, Jaspers Horizontal Task Outputs - Working Paper 3.

Johansson T. (2008), Municipal contracting out: governance choices, misalignment and performance in Swedish local government, Financial Accountability \& Management, August, pp. 243-264.

Kubisa J. (2006), Liberalisation, privatisation and regulation in the polish local public transport sector, Project Privatization of public services and the impact on quality, employment and productivity (PIQUE), Project funded under the European Commission's $6^{\text {th }}$ Framework Programme, Warsaw.

Longva F., Osland O., (2010), Regulating the regulator: The impact of professional procuring bodies on local public transport policy and its effectiveness, Research in Transportation Economics, 29, pp. 118-123.

Loser P. (2009), Austrian local and regional public transport, CIRIEC Working Paper $\mathrm{n}^{\circ} 8$, Liege.

Mallard G., Glaister S. (2008), Transport Economics, Theory, Application and Policy, Basingstoke, Palgrave Macmillan.

Martin Urbano P. et al. (2010), Spanish Local and Regional Public Transport, CIRIEC Working Paper $\mathrm{n}^{\circ} 2$, Liege.

Mattison O., Thomasson A. (2007), The strategic process and its impact on the outcome of a tender, Annals of Public and Cooperative Economics 78: 3, pp. 439554.

Millward R. (2010), Public enterprise in the modern western world. An historical analysis, Paper presented at the Ninth Milan European Economy Workshop, Milan.

Nash C., Wolanski M. (2010), Workshop report - Benchmarking the outcome of competitive tendering, Research in Transportation Economics, 29, pp. 6-10.

Obermann G. (2007), The role of the state as guarantor of public services: transaction cost issues and empirical evidence, Annals of Public and Cooperative Economics 78: 3, pp. 475-500. 
Oecd, 2005, Guidelines on Corporate Governance of State-owned Enterprises, Oecd Publishing, Paris.

Osculati F., Zatti A. (2005), The Services of General Economic Interest. The Case of Local Public Transport in Italy, Il Politico, n. 210, pp. 411-447.

Osculati F., Zatti A. (2008), Local Public Transport in Italy: The Long and Tortuous Way of a Tentative Reform, CIRIEC Working Paper $n^{\circ} 8$, Liege.

Pond R. (2006), Liberalisation, privatisation and regulation in the UK local public transport sector, Privatization of public services and the impact on quality, employment and productivity (PIQUE), Project funded under the European Commission's $6^{\text {th }}$ Framework Programme, London.

Roy W., Yvrande-Billon A. (2007), Ownership, Contractual Practices and Technical Efficiency: The Case of Urban Public Transport in France, Journal of Transport Economics and Policy, Volume 41, N.2, pp. 257-282.

Shulten T. (2006), Liberalisation, privatisation and regulation in the German local public transport sector, Privatization of public services and the impact on quality, employment and productivity (PIQUE), Project funded under the European Commission's $6^{\text {th }}$ Framework Programme, Dusseldorf.

Shulten T., Brandt T., Hermann C. (2008), Liberalisation and privatisation of public services and strategic options for European trade unions, Transfer 14(2), pp. 295311.

Sumet Ongkittikul S. (2007), Regulatory reform in European Public Transport: What Can We Learn?, TDRI Quarterly Review, Vol. 22 N. 2, pp. 10-15.

Thiry B., Monnier L., Introduction: the General Interest: its Architecture and Dynamics, "Annals of Public and Cooperative Economics", 69:3, pp. 321.

Thomasson A. (2010), Corporate governance in a public sector context - A study of governance processes in jointly owned municipal companies, paper presented at the ninth Milan European Economy Workshop "An Agenda for the New Public Enteprise. Ownership and governance for the general interest, Milan.

Van de Velde D. M. (1999), Organisational forms and entrepreneurship in public transport. Part 1: classifying organisational forms, Transport Policy, 6, pp. 147-157.

Van de Velde D. M. (2003), Regulation and competition in the European land transport industry: some recent evolutions, $8^{\text {th }}$ Conference on Competition and Ownership in Land Passenger Transport, Rio de Janeiro, 14-18 September.

Van de Velde et al. (2008), Contracting in urban public transport, Submitted to ECDG TREN, Amsterdam.

Van Egmond P., Nijkamp P., Vindigni G. (2003), A comparative analysis of the performance of urban public transport systems in Europe, International Social Science Journal, Volume 55, Issue 176, pp. 235-247.

Verhoest K, Sys J. (2006), Liberalisation, privatisation and regulation in the Belgian local public transport sector, , Privatization of public services and the impact on quality, employment and productivity (PIQUE), Project funded under the European Commission's $6^{\text {th }}$ Framework Programme, Dusseldorf.

Wolanski M. (2008), Competition in polish urban public transport, Association of European Transport and contributors.

Zadra-Veil C. (2010), Urban Transport in France, CIRIEC Working Paper $\mathrm{n}^{\circ} 6$, Liege. 
This yearly series of working papers (WP) aims to publish essentially works in English or in French resulting from the scientific network of CIRIEC and more specifically its working groups. The WP are submitted to a review process and are published under the responsibility of the President of the International Scientific Council, the president of the scientific Commissions or the working groups coordinators and of the editor of the CIRIEC international scientific journal, the Annals of Public and Cooperative Economics.

These contributions may be published afterwards in a scientific journal or book.

The contents of the working papers do not involve CIRIEC's responsibility but solely the author(s') one.

The submissions are to be sent to CIRIEC, Université de Liège au Sart Tilman, Bât B33 (bte 6), BE-4000 Liège, Belgique.

Cette collection annuelle de Working Papers (WP) est destinée à accueillir essentiellement des travaux en français ou en anglais issus du réseau scientifique du CIRIEC et en particulier de ses groupes de travail. Les WP font l'objet d'une procédure d'évaluation et sont publiés sous la responsabilité du président du Conseil scientifique international, des présidents des Commissions scientifiques ou des coordinateurs des groupes de travail et de la rédactrice de la revue scientifique internationale du CIRIEC, les Annales de l'économie publique, sociale et coopérative.

Ces contributions peuvent faire l'objet d'une publication scientifique ultérieure.

Le contenu des WP n'engage en rien la responsabilité du CIRIEC mais uniquement celle du ou des auteurs.

Les soumissions sont à envoyer à l'adresse du CIRIEC, Université de Liège au Sart Tilman, Bât B33 (bte 6), BE-4000 Liège, Belgique. 


\section{Publications}

2011/01 Maintaining Local Transport Services in Japan

Fumitoshi MIZUTANI \& Shinichi SAITO

2011/02 Water Supply Utility Businesses in Japan

Shoji KUSUDA

2011/03 Municipal Solid Waste Management in Japan - Present Situation and Characteristics

Naohisa WADA

2011/04 La gestion intégrée des déchets solides en Algérie. Contraintes et limites de sa mise en oeuvre

Brahim DJEMACI \& Malika AHMED ZAÏD-CHERTOUK

2011/05 Local public services: Facts, experiences and prospects

Water services: what are the main challenges?

$\underline{\text { Synthesis report }}$

Pierre BAUBY

2011/06 Local public services: Facts, experiences and prospects

New organizational models in European Local Public Transport:

from Myth to Reality.

Andrea ZATTI

Synthesis report

2011/07 Local public services: Facts, experiences and prospects

The municipal waste management sector in Europe: shifting boundaries between public service and the market. Synthesis report Barbara ANTONIOLI \& Antonio MASSARUTTO 
CIRIEC (International Centre of Research and Information on the Public, Social and Cooperative Economy) is a non governmental international scientific organization.

Its objectives are to undertake and promote the collection of information, scientific research, and the publication of works on economic sectors and activities oriented towards the service of the general and collective interest: action by the State and the local and regional public authorities in economic fields (economic policy, regulation); public utilities; public and mixed enterprises at the national, regional and municipal levels; the so-called "social economy" (not-for-profit economy, cooperatives, mutuals, and non-profit organizations); etc.

In these fields CIRIEC seeks to offer information and opportunities for mutual enrichment to practitioners and academics and for promoting international action. It develops activities of interest for both managers and researchers.
Le CIRIEC (Centre International de Recherches et d'Information sur I'Economie Publique, Sociale et Coopérative) est une organisation scientifique internationale non gouvernementale.

Ses objectifs sont d'assurer et de promouvoir la collecte d'informations, la recherche scientifique et la publication de travaux concernant les secteurs économiques et les activités orientés vers le service de l'intérêt général et collectif : l'action de l'Etat et des pouvoirs publics régionaux et locaux dans les domaines économiques (politique économique, régulation); les services publics; les entreprises publiques et mixtes aux niveaux national, régional et local ; l'économie sociale : coopératives, mutuelles et associations sans but lucratif ; etc.

Le CIRIEC a pour but de mettre à la disposition des praticiens et des scientifiques des informations concernant ces différents domaines, de leur fournir des occasions d'enrichissement mutuel et de promouvoir une action et une réflexion internationales. Il développe des activités qui intéressent tant les gestionnaires que les chercheurs scientifiques.

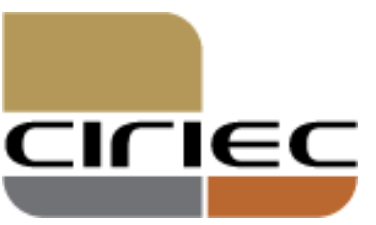

International Centre of Research and Information on the Public, Social and Cooperative Economy - aisbl Centre international de Recherches et d'Information sur l'Economie Publique, Sociale et Coopérative - aisbl

Université de Liège au Sart-Tilman

Bât. B33 - bte 6

BE-4000 Liège (Belgium)
Tel. : $+32(0) 43662746$ Fax : $+32(0) 43662958$

E-mail : ciriec@ulg.ac.be http://www.ciniec.ulq.ac.be 